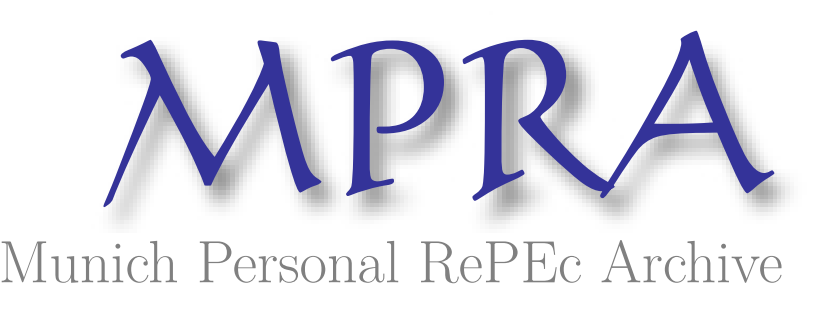

\title{
The network effect of deglobalisation on European regions
}

Giammetti, Raffaele and Papi, Luca and Teobaldelli, Desiree and Ticchi, Davide

Marche Polytechnic University, University of Urbino

16 December 2021

Online at https://mpra.ub.uni-muenchen.de/111135/

MPRA Paper No. 111135, posted 20 Dec 2021 14:17 UTC 


\title{
The network effect of deglobalisation on European regions
}

\author{
Raffaele Giammetti ${ }^{*}$ Luca Papi ${ }^{*}$, Désirée Teobaldelli†, Davide Ticchi ${ }^{*}$
}

First version: September 2021

This version: December 2021

\begin{abstract}
This paper investigates the effects of a retreat from global economic integration on the European regional production network for the period 2000-2010. We find that production has become increasingly fragmented, although the degree of heterogeneity across regions is substantial. This heterogeneity is also present in the direct and indirect effects of three different deglobalisation scenarios that we simulate. Our results show that deglobalisation generates winners and losers. Specifically, two groups of regions emerge; regions that would benefit from a return to a less integrated world, and regions that would instead gain from a strengthening of the European production network.
\end{abstract}

Keywords: Reshoring, Global Value Chains, production networks, input-output, regional fragmentation, supply chains interruption.

JEL classification: D57, F16, F62, F66.

\footnotetext{
* Marche Polytechnic University, Department of Economics and Social Sciences, Piazzale Martelli 8, 60121, Ancona (Italy).Email: r.giammetti@univpm.it; 1.papi@univpm.it; d.ticchi@univpm.it (corresponding author).

${ }^{\dagger}$ University of Urbino, Department of Law, Via Matteotti 1, 61029, Urbino (Italy). Email: desiree.teobaldelli@uniurb.it
} 


\section{Introduction}

Following the Brexit, the US-China tensions, and the outbreak of the COVID-19 pandemic the world economy is retreating from global economic integration (Baldwin and Evenett, 2020; Irwin, 2020). Policymakers, business leaders, and the popular press are questioning whether global value chains (GVCs) have been stretched too far. In the academic debate it has been argued that reshaping GVCs, possibly making them shorter, more domestic, or more diversified, could improve production networks resilience (Gereffi, 2020). While there are conflicting views on this position (Miroudot, 2020), there is instead a widespread consensus that GVCs may undergo certain reconfigurations and shortening in the near de-globalised future (Antràs, 2021; Brakman et al., 2020; Kano and Oh, 2020). However, despite the debate on these issues is attracting a large and increasing attention there is exceedingly little empirical work on the economic implications of deglobalisation, and none that focuses on the network effects at a regional level. This paper aims to fill this gap.

In particular, we aim at analysing the potential impact of deglobalisation on European Union (EU) regional economies by addressing the following questions: How would EU regions be affected by the interruption of supply chains? What economic consequences would a return to less integrated trade have for EU regions? What effect would a shortening of extra-EU value chains have on EU regions?

To answer these questions, we here develop a scenario analysis in a global input-output framework using the EUREGIO database that includes data for 14 industries in 246 NUTS 2 regions of the EU-25, plus data at the country-level for the same 14 industries in Bulgaria, Romania and other 14 extra-EU trading partners, for a total of 41 countries. Specifically, we study the impact on EU regional economies of three different kind of deglobalisation scenarios characterised, respectively, by: (1) the end of foreign intermediate input flows; (2) a return to the past production schemes and trade patterns; (3) a Europeanisation of the GVCs.

Despite the definition of globalisation is multifaceted and complex (Livesey, 2018), it can be defined as the rise in international flows of intermediate goods and services (Feenstra and Hanson, 1996; Hummels et al., 1998). Hence, a natural way of modelling deglobalisation is to consider the case where there is a large reduction of intermediates. Therefore, borrowing from previous studies on the impact of trade restrictions (Chen et al. 2018; Eppinger et al. 2021; Giammetti et al., 2020b), in our first scenario we quantify the shares of EU regions value-added that would be at risk following a deglobalisation process in hypothetical situations where there is: (i) a complete interruption of imports and exports in intermediate inputs; (ii) a partial interruption involving only 
extra-EU countries, thus leaving the deliveries of inputs between EU regions unchanged; and (iii) a partial interruption involving only the deliveries between EU regions, leaving the input relationships with extra-EU countries unchanged.

In the second scenario, we aim at understanding how EU regional economies would respond if we could go back in time evaluating how the value-added in 2010 of such regions would change if production took place with the production schemes and trade patterns of 2000. In the debate on the backlash of globalisation, reference is often made to the sentiment of the so-called losers of hyperglobalisation or to a process of integration of world economies that has gone too far (Colantone et al., 2021). Hence, we here try to answer the question about what would happen if we could go back to a less globalised world with the same or similar characteristics of the past.

The third scenario addresses the issue of GVCs reshoring (Strange, 2020) by simulating the effects on EU regional economies (and extra-EU countries) of a hypothetical situation where the EU regions totally replace the intermediate inputs imported from extra-EU countries with the same intermediates from other EU countries. The reasons motivating this scenario are rooted in the debate about the opportunity and effects of shortening the value chains (see Di Stefano, 2021, for a review) and the European strategic autonomy (Tocci, 2021)-i.e., the deepening of the single market and the promotion of intra-EU value chains - that has been strengthened by the widespread disruptions to GVCs caused by the COVID-19 pandemic (OECD, 2020).

We model the three scenarios by employing the hypothetical extraction method and some of its extensions (Dietzenbacher and Lahr, 2013; Dietzenbacher et al., 2019) as this is a standard inputoutput tool widely used in the recent GVCs literature for studying how the value-added of a sector, a region, or a country, changes following the perturbation of the input requirements matrix (Los et al., 2017; Chen et al., 2018; Giammetti et al., 2020a; Giammetti et al., 2020b). Our approach is comprehensive and granular as it includes direct and indirect trade via GVCs and provides estimates of the impact of our deglobalisation scenarios at the industry level. Including GVCs and inputoutput connections allows us to evaluate the implications deglobalisation might have on third-party regions and countries. This approach has also the advantage of providing detailed information on the distributional effects of deglobalisation and to estimate its impact on EU regional economies without the need of assumptions on future prices, trade elasticities, and related international substitution patterns.

Two issues are worth discussing. First, regarding the methodology, we recognise that inputoutput linkages and indirect effects generated by the interruption of GVCs could also be studied employing other models such as the widely used new quantitative trade models (NQTMs). However, as such models need to be calibrated, the use of NQTMs to study the impact of 
deglobalisation would require assumptions on the strength of interregional and international substitution patterns as well as the use of trade elasticities. Hence, a shortcoming of these models in estimating the effects of large trade shocks may arise from the fact that such key parameters (that can heavily influence the outcome of the simulations) might not well describe behavioural changes following a trade policy shock, as they have been estimated in a pre-impact scenario characterised by (generally) limited variations in trade barriers (see for more on this point Chen et al., 2018). ${ }^{1}$ While the standard input-output framework and the NQTMs have both pros and cons, we opted for the former approach because its simplicity and parsimony make it suitable for providing quick and reasonably accurate evaluations of the economic effects of different deglobalisation scenarios.

Second, we also acknowledge that the first and third scenario represent extreme cases of deglobalisation as they involve the complete interruption of value chains or the total replacement of intermediates with very large effects on trade flows. However, two points should be beard in mind in evaluating the results of these scenarios. One is that the aim of our analysis is not to accurately measure the losses from deglobalisation as nobody knows how exactly such a process could eventually take place. Rather, we are interested in understanding, other things equal, the degree of exposure and the possible heterogeneous distribution of gains and losses of deglobalisation across EU regional economies. Such results might be insightful for various reasons, including the political factors that could ultimately shape such a process. ${ }^{2}$ Moreover, Dietzenbacher and Lahr (2013) have shown that there is basically no difference in results between the complete and the partial extraction when using the hypothetical extraction method to study distributional impacts. This means that the differences between the results in our first and third scenario and the ones obtained by considering intermediate cases where a share of intermediates (a half, a third or any other) is eliminated or replaced would be minor.

Before presenting the results of the scenario analysis, we describe the trends in international fragmentation of the EU regional production network over the period 2000-2010. The purpose of this study is to strengthen our research question. If most production in EU regions were bounded within domestic borders, a hypothetical future scenario of deglobalisation would be of less concern

\footnotetext{
${ }^{1}$ It should be acknowledged that also the input-output approach and the hypothetical extraction method show limitations. These models are basically accounting frameworks, rather than fully specified economic models. They start from exogenously given final demand and trace the value added generated at the various stages of production in an international input-output model without explicitly modelling the interaction of prices and quantities like in computable general equilibrium models and NQTMs. However, as shown by recent literature (see, among others, Los et al., 2017; Chen et al., 2018; Giammetti, 2020) they are nevertheless shown to be a powerful tool for impact analyses and for studying the direct and indirect effects of a shock affecting GVCs.

${ }^{2}$ While it goes beyond the aim of this paper to evaluate the losses generated by the lockdown policies implemented following the COVID-19 pandemic, it is nevertheless worth noting that the analysis developed here might provide some useful insights on short-term consequences of rare and extraordinary events that lead to sudden and large interruption of GVCs.
} 
for citizens and policy-makers. However, in line with the results in the literature on production fragmentation (Los et al., 2015), we find that the EU regional production network has become increasingly fragmented since 2000. And, within this trend, we also find that intra-EU fragmentation is dominant in EU value chains, although the trend towards the fragmentation of production outside the EU shows a faster pattern. These findings help motivating our scenario analysis as they suggest that: (i) a shock generated by a deglobalisation process would rapidly spread directly and indirectly through GVCs across EU regions; (ii) the regions of our sample are asymmetrically exposed to the interruption of intra-EU and extra-EU GVCs.

The results of the scenario analysis show that the degree of exposure of EU regions to deglobalisation is highly heterogeneous but a clear pattern also emerges: neighbouring regions, even beyond national borders, exhibit similar exposure to deglobalisation. This suggests that gravity plays a key role in shaping trade flows and that neighbouring regions are likely to belong to the same value chains (Johnson and Noguera, 2012b). Notably, we unveil three main regional value chains: the Central-Eastern bloc, highly integrated within the interregional production network, the Northern bloc, mainly integrated with countries outside the EU, and the Southern bloc, less dependent on regional and global supply chains.

Moreover, in line with the standard trade theory which highlights the presence of winners and losers from globalisation, the findings of the second scenario suggest that a return to a less globalised world would also create winners, not just losers; and this evidence holds at the industry, region, and country level. This asymmetry is even more interesting when compared with the results of the third scenario showing that most of the top winner regions from a Europeanisation of GVCs are among the top losers from a return to a less integrated production network. In this sense, our results reveal the presence of two classes of regions that may have conflicting interests: some regions that would benefit from a return to the past when the fragmentation of production was more limited, and others that would instead gain from greater integration of EU production chains. The existence of such divergent interests is also important for the debate on the drivers of the so-called European discontent (Dijkstra et al., 2020; De Ruyter et al., 2021); more precisely, our findings might add new elements to the growing body of work suggesting that EU backlash is rooted in the reaction among citizens unable to reap benefits from increasingly globalised economies (DíazLanchas et al., 2021; Hobolt, 2016; Lechler, 2019).

This paper is closely related to the literature investigating the economic effects of deglobalisation and GVCs reconfiguration. Some authors have argued that globalisation and deglobalisation are recurring phases of our economic system (James, 2017; van Bergeijk, 2018, 2019) and others have emphasized how the global pandemic is accelerating deglobalisation and 
structural changes that are already taking place (Livesey, 2018; Irwin, 2020; Antràs, 2021). And while the study of the economic effects associated with a process of deglobalisation appears to be of major importance, the empirical literature on deglobalisation is meagre and limited to few exceptions, such as Hillebrand (2010) and Eppinger et al. (2021). Hillebrand (2010) estimates the impact of a deglobalisation scenario on the world economy and concludes that a retreat from globalisation would have a profound negative impact on most countries and income groups. Most closely related to our work is Eppinger et al. (2021) who employ a quantitative trade model with multiple country-sectors and input-output linkages to simulate GVCs decoupling finding that its effect on welfare losses far exceeds any benefit from lower shock exposure.

Our analysis builds on the strand of literature using global input-output tables to link trade to value-added (Johnson and Noguera, 2012a; Koopman et al., 2014; Timmer et al., 2014) and it is closely related to the growing body of research adopting the input-output method of hypothetical extraction to evaluate the impact of GVCs disruptions and reconfigurations. In the latter strand of this literature, recent works has emphasised the role of input-output linkages and GVCs in amplifying the effects of protectionism and bilateral trade conflicts (Hubert, 2019) such as Brexit (Los et al., 2017; Chen et al., 2018; Giammetti, 2020; Giammetti et al. 2020a) and the US-China tensions (Wang and Hewings, 2020). However, most of these works differ from ours as they mainly develop country level analysis (exceptions are Los et al., 2017, and Chen et al., 2018) and do not specifically investigate the impact of deglobalisation.

Finally, our work is also related to the strand of the fast-growing literature studying how the disruptions to GVCs generated by lockdown policies and social distancing measures following the COVID-19 pandemic have affected the economy of selected countries and international trade. Specifically, close to our paper are those building on an input-output and GVCs framework (Bonadio et al., 2020; Guan et al., 2020; Mandel and Veetil, 2020; Pichler et al., 2020; Ferraresi et al., 2021; Reissl et al., 2021) and, especially, the studies adopting the hypothetical extraction method (Giammetti et al., 2020a; Haddad et al., 2020; Bonet-Morón et al., 2020; Sanguinet et al., 2021). Despite some common features, our paper distinguishes from the contributions in this literature along many dimensions, such as the multi-regional approach, the specific focus on deglobalisation and, more importantly, the counterfactual assessment of the costs and benefits of GVCs reconfigurations.

The rest of the paper is organised as follows. Section 2 outlines the methodology and data employed. Section 3 describes the fragmentation of EU regional production network. Sections 4, 5 and 6 present the results on the impact of the three deglobalisation scenarios. Section 7 concludes. 


\section{Methodology and Data}

This section provides some intuitive insights of the multi-regional input-output framework, followed by a brief description of the methodologies used in the scenario analyses and the EUREGIO database. A more technical and detailed presentation of the methodologies employed (including a focus on the measurement of international fragmentation of value chains in a regional setting) is reported in the Online Appendix A.

Our methods are rooted in the input-output analysis introduced by Leontief (1936), the multiple regions extension made by Isard (1951) and Miller (1966), and the more recent studies on GVCs in an input-output framework inaugurated by Timmer et al. (2013) and Timmer et al. (2014). In all this literature the modelling of input-output structures of industries is central. The input-output structure of an industry includes the information about the amount and type of intermediate inputs needed to produce one unit of output. Based on the Leontief model extended to the linkages across industries, regions, and countries, one can trace the gross output in all stages of production that is needed to produce one unit of final demand.

For example, take the car production in Piemonte (Italy). Demand for Italian cars will in the first instance raise the output of Piemonte and the Italian car industry. But the assembly of an Italian car produced in Piemonte requires car parts and components that are produced by different sectors in different regions and countries such as steel, glass, plastic, rubber, but also energy, and various business services such as logistics, transport, marketing, and financial services. These intermediate goods and services need to be produced as well, thus raising output in the industries delivering them, say the financial services industry placed in Lombardia (Italy) and London (UK), the glass industry placed in Limburg (Netherlands), and the Chinese textile industry. In turn, this will raise output in sectors and regions delivering intermediates to these industries and so on. If we know the gross-output flows associated with a particular level of final demand, we can derive the value added by multiplying these flows with the value-added to the gross-output ratio for each industry (Timmer et al., 2013). By construction, the sum of value added across all industries involved in production will be equal to the value of the final demand.

More formally, by applying standard input-output methods to global input-output tables one can decompose value chains of final products that are identified by the last stage of production: a particular industry $i$ located in a specific region/country $r$. Let us assume that the world economy consists of $C$ countries, each of them includes a (variable) number of regions $R$, and each region is comprised of $N$ industries. To decompose the value of a final product into value added contribution 
in any region and country in the world we can start with an equation that has been a standard tool in input-output analysis for over decades (see Miller and Blair, 2009):

$$
\mathbf{v}=\widehat{\mathbf{V}}(\mathbf{I}-\mathbf{A})^{-1} \mathbf{F i}
$$

In this equation (see the Online Appendix $\mathrm{A}$ for details), $\mathbf{v}$ is a vector of which the typical element is the value added of industry $i$ in region/country $r . \widehat{\mathbf{V}}$ is a diagonal matrix, of which the typical element on the main diagonal, is the value-added over gross output ratio for each of the region/country-industries. $\mathbf{A}$ is the input requirements matrix, also known as the technical coefficients matrix, in which the typical element is the ratio of input supplied by $i$ and bought by $j$ over the gross output of sector $j$. $(\mathbf{I}-\mathbf{A})^{-1}$ is the well-known Leontief inverse, or multiplier matrix, in which its typical element gives the gross output of industry $i$ in region/country $r$ needed to produce one unit of final demand for the output of industry $j$ in region/country $s$. Finally, $\mathbf{F}$ is the matrix of industry final demands, and $\mathbf{i}$ is the summation vector, i.e. a vector of all ones.

We employ the hypothetical extraction method and two of its extensions to modify the equation (1) and evaluate the impact of three different deglobalisation scenarios on EU regions. The hypothetical extraction method is a standard input-output tool widely used in the recent literature evaluating the impact of GVCs disruptions and reconfigurations (see among others Los et al., 2017, Chen et al., 2018; Giammetti, 2020). ${ }^{3}$ In its standard version, the hypothetical extraction method considers the hypothetical situation in which a certain industry is no longer operational. Using the input-output framework, the hypothetical extraction method calculates the outputs in the entire economy that are necessary for the original final demands. The difference between the original outputs and the hypothetical extraction outputs (which are smaller than the original outputs) is a measure of the linkages of the deleted industry. This standard case can be easily generalised to study how the value-added of a sector, a region, or a country, changes following the zeroing (extraction) of one or more sectors from the input requirements matrix A. This is exactly what we do in Section 4 to compute the exposure of EU regions to the complete interruption of intermediate input flows coming from and to foreign countries. It should be noted that this scenario, although highly stylized and extreme to a certain extent, is widely used as a benchmark scenario in both the input-output (Chen et al., 2018) and the NQTM (Eppinger et al., 2021) literature. Specifically, we

\footnotetext{
${ }^{3}$ A detailed mathematical exposition of the hypothetical extraction method and its extensions used in this paper is provided in the Online Appendix A. For insights and detail of this method, see also Miller and Lahr (2001), Los et al. (2016), Chen et al. (2018), Dietzenbacher et al. (2019), and Giammetti (2020). It is worth emphasizing that this method is flexible and can be extended and modified to answer different research questions. For example, Los et al. (2016) and Los and Timmer (2018) use the hypothetical extraction method to calculate different measures of trade in value-added. Giammetti et al. (2020b) use this method to unveil the key sectors in the EU production network.
} 
follow most closely the methodology that Chen et al. (2018) and Giammetti et al. (2020b) implemented to study the degree to which EU regions and countries are exposed to the consequences of Brexit. In our experiment, we hypothesize that industries in EU regions stop importing and exporting intermediate inputs. Formally, this translates into the nullification of the matrix blocs of $\mathbf{A}$ relative to foreign import and export of inputs, such that the new matrix $\mathbf{A}^{*}$ consists of domestic matrix blocs and zero elsewhere. We also hypothesize two intermediate cases: (i) the case in which the interruption of intermediate flows involves only foreign countries, thus leaving the deliveries of inputs between EU regions unchanged; and (ii) the case in which the interruption of intermediate value chains involves only the deliveries between EU regions, leaving the input relationships with extra-EU countries unchanged. In the first case (i), the matrix blocs of $\mathbf{A}$ relating to import and export of inputs between EU regions and extra-EU countries are zeroed. Vice versa, in case (ii), are zeroed the matrix blocs of $\mathbf{A}$ relating the deliveries of inputs across EU regions. Once replaced $\mathbf{A}$ in equation (1) with the proper $\mathbf{A}^{*}$ we obtain the new value-added:

$$
\mathbf{v}^{*}=\widehat{\mathbf{V}}\left(\mathbf{I}-\mathbf{A}^{*}\right)^{-1} \mathbf{F i} \text {. }
$$

The relative difference between the new value-added and the pre-extraction value-added represents the relative change in value-added and provides a quantitative indication about the dependency of EU regions to foreign intermediate inputs:

$$
\operatorname{rCiVA}=\frac{\mathbf{v}^{*}-\mathbf{v}}{\mathbf{v}}
$$

More generally, this ratio (rCiVA) might also be considered as an index bounded between 0 and 1 of the extent to which EU regions are exposed to interruption of foreign intermediate value chains. ${ }^{4}$

In the other two scenarios, we implement the same methodology and make use of a variant of equations (2) and (3). The difference lies in the modification of the input requirements matrix $\mathbf{A}$. In scenario 2 we ask ourselves what would happen if we could go back in time and resume the production schemes of the past. More precisely, leaving $\widehat{\mathbf{V}}$ and $\mathbf{F}$ fixed at the 2010 values (the last

\footnotetext{
${ }^{4}$ This index also provides indications of the likely resilience of EU regions to GVCs shocks. For recent empirical contributions on regional resilience see Brakman et al. (2015) and Gong et al. (2020). On the multifaced notion of regional resilience see Hassink (2010) and Hassink and Gong (2020).
} 
year available), we investigate how the value-added would change if the matrix of the technical coefficients A were fixed at the year 2000: ${ }^{5}$

$$
\begin{gathered}
\mathbf{v}^{*}=\widehat{\mathbf{V}}_{2010}\left(\mathbf{I}-\mathbf{A}_{2000}\right)^{-1} \mathbf{F i}_{2010} \\
\operatorname{rCiVA}=\frac{\mathbf{v}^{*}-\mathbf{v}_{2010}}{\mathbf{v}_{2010}}
\end{gathered}
$$

Then, using equation (5), we analyse the relative change of value-added.

In scenario 3, we aim to enrich the debate on EU strategic autonomy and EU sovereignty. These concepts encompass a greater potential for independence, self-reliance and resilience in a wide range of fields - such as defence, trade, industrial policy, digital policy, economic and monetary policy, and health policy_following a series of events in recent years that have exposed Europe's vulnerability to external shocks. In scenario 3 we focus on the issues related to trade autonomy and the possibility of shortening GVCs. Specifically, we test the impact of a Europeanisation of GVCs by assuming that EU regions stop importing intermediates from non-EU countries and replace them with intermediates produced in Europe. To do so, we refer to the global extraction method (Dietzenbacher et al., 2019) used by Giammetti (2020) to study the effect of import substitution policy in a post-Brexit world. The global extraction method consists of replacing the extracted inputs with inputs from other sources. As an example, suppose the extra-EU glass industry is extracted. Car production in Piemonte requires textile inputs and imagine that 30 percent of them originate in extra-EU countries, 35 percent from Stuttgart, 15 percent from Île-deFrance, and 20 percent from Greater Manchester. Since Piemonte can no longer buy inputs outside the EU, we assume that the imported textile inputs are all increased by the same percentage (in this case 42.9 percent), so that they add up to 100 percent again. Thus, the car industry in Piemonte now imports 50 percent from Stuttgart, 21 percent from Île-de-France, and 29 percent from Greater Manchester. Again, we indicate with $\mathbf{A}^{*}$ the new input requirements matrix and we use equation (2) to assess the impact of the Europeanisation of GVCs scenario. It should be noted that in the method applied the total input requirements remains fixed. Thus, the column sums of the pre- and postgeneralized extraction $\mathbf{A}$ and $\mathbf{A}^{*}$ are equivalent. ${ }^{6}$

\footnotetext{
${ }^{5}$ Due to data limitations, we cannot go back to before 2000. However, this is an interesting year as it precedes the full introduction of the euro and the entry of China into the WTO.

${ }^{6}$ It is worth emphasizing that the effects of re-shoring and trade diversion could also be modelled with an NQTM. However, using such kind of models require making assumptions on key parameters such as trade elasticities. Therefore, we prefer a more conservative (admittedly crude) assumption, according to which the missing intermediate flows are allocated proportionally over the columns of the global input-output matrix.
} 
Our analysis is based on the EUREGIO database that is the first time-series (annual, 20002010) of global input-output tables with information at regional level for the entire large trading bloc of the EU-25 countries (for a detailed description see Thissen et al., 2018). ${ }^{7}$ Specifically, the database contains information for 14 industries in 246 NUTS 2 regions of the EU-25, and the same information at country-level for Bulgaria, Romania and other 14 extra-EU trading partners (i.e., Australia, Brazil, Canada, China, India, Indonesia, Japan, Korea, Mexico, Russia, Taiwan, Turkey, USA, and a macro-region called Rest of the World). We use the tables for the years 2000 and 2010 as the 2010 tables are the most recent available. However, Chen et al. (2018) and Timmer et al. (2016) argue that there has been a limited variation in the degree of international fragmentation of production since 2011, which implies that our results should not change following the use of more recent data. ${ }^{8}$ Finally, another drawback of the EUREGIO database is related to the issue that the interregional trade flows have been estimated using transportation survey data for 2000, which imply that the results in some longitudinal analyses should be taken with caution (though this database is widely used also for multi-year analyses; see among others Brakman et al., 2021; Carrascal Incera et al., 2021; IJtsma and Los, 2020). However, our main findings should not be affected significantly by this shortcoming of the database since the analysis in the first and third scenarios only make use of the last available table, and it is not clear the potential distortions induced in the results of scenario 2 where we use the table of the year 2000 as a reference point for the input requirement matrix. ${ }^{9}$

\section{The fragmentation of the European regional production network}

This section leads the way to the scenario analysis by providing a description of the trends in international fragmentation of the EU regional production network over the period 2000-2010. We first document an increasing trend in the global fragmentation of EU regional production. This preliminary result is useful to show that due to the high fragmentation of production, investigations on the effects of deglobalisation on EU regions are needed. Then, we focus on the geography of

\footnotetext{
7 The measurement of production fragmentation and the assessment of the direct and indirect impact of deglobalisation on EU regions require international input-output tables that cover EU regional economies and extra-EU economies.

${ }^{8}$ It is worth emphasizing that as this is pre-Brexit data one might doubt the results related to the UK and its trade linkages with EU regions. Nevertheless, at the time of writing, the exact nature of the post-Brexit UK-EU relationship and its impact on trade is not known and may be uncertain for a long period of time (Thissen et al., 2020). Hence, our results should not be influenced by Brexit's effects.

${ }^{9}$ While the analysis on fragmentation also employs the table of the year 2000, we remind that the results of this part are not among the main contributions of the paper and, however, the cited limitation of the database should not be of major importance in affecting such results.
} 
fragmentation and answer the question to what extent the trends toward value chain fragmentation have occurred outside or within the EU. ${ }^{10}$ Investigating this question is useful in raising awareness of the dependence of EU regions on extra-EU or intra-EU value chains, and thus to show that the kind of deglobalisation, from extra or intra-EU value chains, is not an irrelevant issue. ${ }^{11}$ Finally, we investigate how global fragmentation tendencies have been more pronounced for some regions and industries than for others.

As surveyed in Johnson (2018), a wide set of measures have been provided to capture different aspects of GVC production and trade. Feenstra and Hanson (1999) were the first to introduce a measure of fragmentation in a macroeconomic setting. This measure is defined as the share of imports in total intermediate inputs in the manufacturing industry. Although this measure has the advantage of being straightforward and simple to compute, it has many drawbacks when used in analyses of international fragmentation. Therefore, we here refer to its generalised version developed by Los et al. (2015) as such measure of fragmentation allows us to decompose the value of a final product into the value-added shares generated in all regions and countries that contribute to its value chain, and to compute the contribution of foreign value-added to the production of EU regions. It should be noted that our contribution is distinguished from Los et al. (2015) as (i) we provide a multi-regional rather than a multi-country analysis, and (ii) we also consider value chains for services rather than focussing only on manufacturing.

Figure 1 displays the scatterplot of the Foreign Value-Added Shares in total Value-Added (FVASs) for EU regions industry in 2000 and 2010. All 14 industries and 246 regions-ofcompletion for which we have data have been included. We have 3,444 value chains. If fragmentation of production has remained constant over the period considered, the observations would have concentrated around the 45-degree line. However, Figure 1 shows that most of the observations (about the 80 percent) are well above the 45-degree line, reflecting an increase in fragmentation. This is especially clear if we compare the slope of the 45-degree line with the estimated slope of an Ordinary Least Squares (OLS) regression. The trend line indicates that the FVASs increased on average of about 40 percent over the period considered.

\footnotetext{
${ }^{10}$ It should be stressed that in this section we could have made a comparative analysis of the fragmentation of added value in one region and others in the same country. However, the in-depth investigation of the fragmentation of production in the EU regional production network is out of the scope of this paper, which is instead mainly devoted to the evaluation of the effects of deglobalisation.

${ }^{11}$ The triple analysis of the fragmentation at global, extra-EU and intra-EU level is strictly connected to the three subcases of scenario 1 in which we quantify the exposure of EU regions to an interruption of the value chains at a global, extra-EU and intra-EU level.
} 


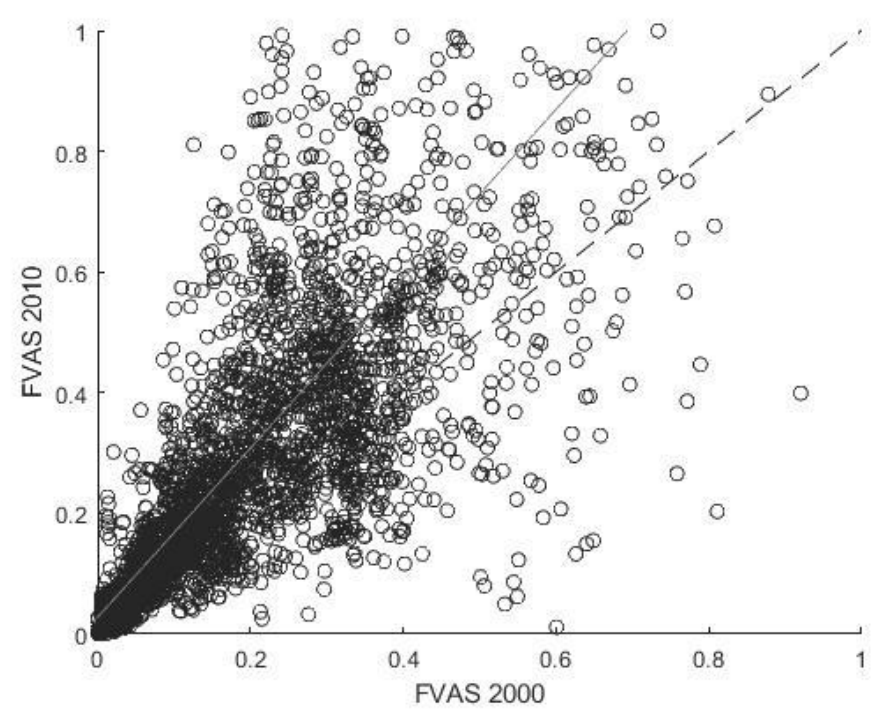

Figure 1. Foreign Value-Added Shares in total Value-Added (2000 and 2010).

This result is consistent with the literature emphasizing the increased density and fragmentation of the international production network (e.g., Henderson et al., 2002; Hummels et al., 2001; Johnson and Noguera, 2012a, 2012b; Timmer et al., 2014). However, such works have not clarified whether such fragmentation of production is mainly regional, taking place within neighboring countries, or mainly global, namely involving far away countries. The evidence in the related literature is mixed. Works based on case studies find that the activities required to build electronic products are increasingly dispersed around the globe (Dedrick et al., 2010), while the production chains of cars fragment both globally and regionally (Sturgeon et al., 2008). Based on econometric analysis and trade statistics, Johnson and Noguera (2012b) and Baldwin and Lopez-Gonzalez (2015) suggest that intraregional trade is more fragmentation-intensive than trade outside regions. This holds true also in the global input-output analysis provided by Los et al. (2015). The authors find that regional fragmentation is dominant in EU value chains, but they show that shares of valueadded outside the EU are increasing the fastest, pointing toward faster global fragmentation. As shown in Figures $2 \mathrm{a}$ and $2 \mathrm{~b}$, our results for the EU regional production network corroborate the cross-country findings of Los et al. (2015).

The scatterplot in Figure 2a shows that extra-EU fragmentation involved more than 80 percent of EU regions' industries. Further, the extra-EU fragmentation of production increased by about 50 percent over the decade considered. This trend is more pronounced than for the shares of valueadded sourced within the EU. By inspecting Figure $2 \mathrm{~b}$ we find that about 73 percent of the observations are above the 45-degree line, and that production fragmentation within the EU regional network increased on average by about 30 percent during 2000-2010. However, the vast majority of 
observations related to extra-EU fragmentation clustered between 20 and 40 percent of FVASs, while the EU-FVASs are also significant on higher shares. This suggests that in absolute terms intra-EU fragmentation is still dominant in EU regional value chains, although the trend towards production fragmentation outside the EU shows a faster pattern.

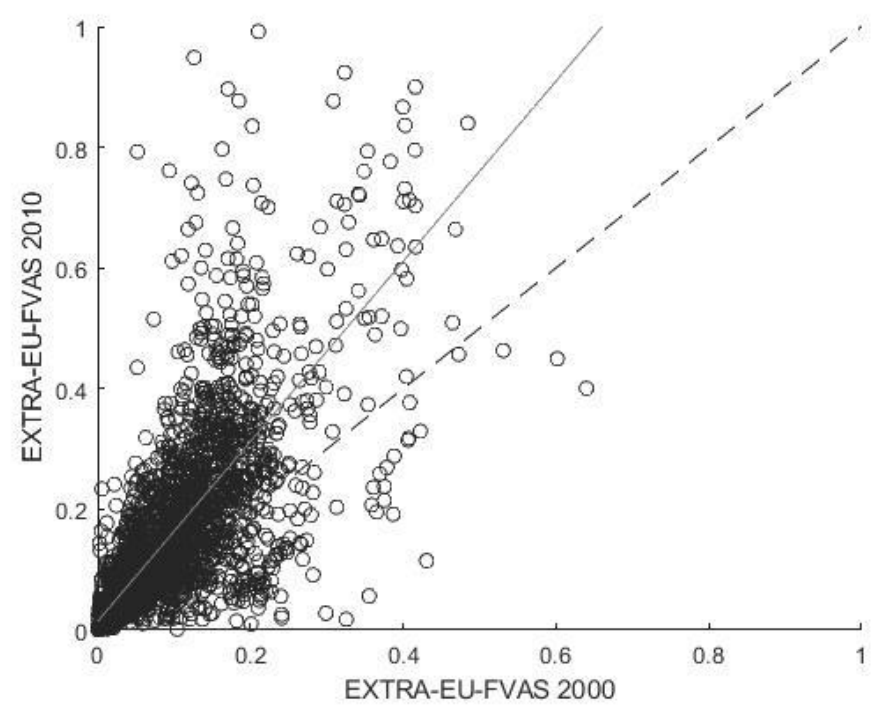

Figure 2a. Foreign Value-Added Shares from outside the EU network in total Value-Added (2000 vs. 2010).

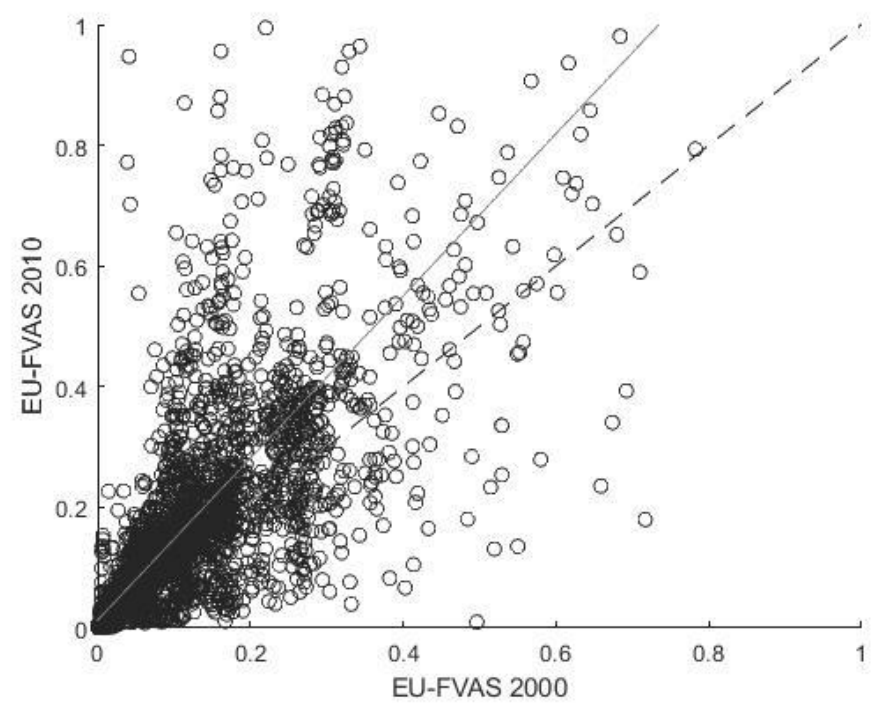

Figure 2b. Foreign Value-Added Shares from within the EU network in total Value-Added (2000 vs. 2010). 
Having ascertained the trend towards fragmentation of production, it should be noted that within this trend there are considerable differences across regions. In Table 1 we report the top 30 regions ranked by respectively FVAS (columns 1-3), EU-FVAS (columns 4-6), and EXTRA-EUFVAS (columns 7-9).

\begin{tabular}{|c|c|c|c|c|c|c|c|c|c|c|c|}
\hline \multirow[b]{4}{*}{ CountryCode_Region } & \multicolumn{3}{|c|}{$\begin{array}{l}\text { Top } 30 \text { regions } \\
\text { ranked by FVAS }\end{array}$} & \multicolumn{4}{|c|}{$\begin{array}{c}\text { Top } 30 \text { regions } \\
\text { ranked by EU-FVAS }\end{array}$} & & \multicolumn{3}{|c|}{$\begin{array}{c}\text { Top } 30 \text { regions } \\
\text { ranked by EXTRA-EU-FVAS }\end{array}$} \\
\hline & (1) & (2) & (3) & & (4) & (5) & (6) & & (7) & (8) & (9) \\
\hline & \multicolumn{3}{|c|}{$2000-2010$} & \multicolumn{4}{|c|}{$2000-2010$} & & \multicolumn{3}{|c|}{$2000-2010$} \\
\hline & FVAS & EU-FVAS & $\begin{array}{c}\text { EXTRA } \\
\text { EU-FVAS }\end{array}$ & CountryCode_Region & FVAS & EU-FVAS & $\begin{array}{c}\text { EXTRA } \\
\text { EU-FVAS }\end{array}$ & Country Code_Region & FVAS & EU-FVAS & $\begin{array}{r}\text { EXTRA } \\
\text { EU-FVAS }\end{array}$ \\
\hline HUN_Kozep-M agy arorszag & 8,5 & 5,0 & 3,5 & LUX_LUX (G-D) & 1,7 & 6,4 & $-4,7$ & MLT_MLT & 5,6 & $-1,5$ & 7,1 \\
\hline HUN_Nyugat-Dunantul & 6,4 & 4,4 & 2,1 & HUN_Kozep-Magy arorszag & 8,5 & 5,0 & 3,5 & IRL_Southern and Eastern & 5,0 & $-0,4$ & 5,4 \\
\hline HUN_Kozep-Dunantul & 6,4 & 4,3 & 2,1 & HUN_Nyugat-Dunantul & 6,4 & 4,4 & 2,1 & FIN_Aland & 1,7 & $-3,1$ & 4,9 \\
\hline HUN_eszak-M agy arorszag & 5,7 & 3,9 & 1,8 & HUN_Kozep-Dunantul & 6,4 & 4,3 & 2,1 & LTU_Lietuva & 5,3 & 0,5 & 4,9 \\
\hline MLT_MLT & 5,6 & $-1,5$ & 7,1 & HUN_Del-Alfold & 5,5 & 4,3 & 1,2 & IRL_Border Midlands & 3,0 & $-1,6$ & 4,6 \\
\hline HUN_Del-Alfold & 5,5 & 4,3 & 1,2 & HUN_eszak-M agy arorszag & 5,7 & 3,9 & 1,8 & FIN_Pohjois-Suomi & $-6,0$ & $-9,6$ & 3,6 \\
\hline LTU_Lietuva & 5,3 & 0,5 & 4,9 & HUN_eszak-Alfold & 5,3 & 3,8 & 1,5 & FIN_Lansi-Suomi & $-4,1$ & $-7,7$ & 3,6 \\
\hline DEU_Dresden & 5,3 & 2,9 & 2,4 & HUN_Del-Dunantul & 4,7 & 3,8 & 0,9 & HUN_Kozep-M agy arorszag & 8,5 & 5,0 & 3,5 \\
\hline HUN_eszak-Alfold & 5,3 & 3,8 & 1,5 & NLD_Groningen & 4,4 & 3,2 & 1,2 & SWE_Västsverige & 0,5 & $-2,9$ & 3,4 \\
\hline IRL_Southern and Eastern & 5,0 & $-0,4$ & 5,4 & NLD_Drenthe & 3,4 & 3,0 & 0,5 & SWE_Stockholm & 1,2 & $-2,1$ & 3,2 \\
\hline DEU_Thüringen & 5,0 & 2,8 & 2,2 & DEU_Dresden & 5,3 & 2,9 & 2,4 & POL_Mazowieckie & 5,0 & 1,8 & 3,1 \\
\hline POL_Mazowieckie & 5,0 & 1,8 & 3,1 & DEU_Thüringen & 5,0 & 2,8 & 2,2 & SWE_Småland med oarna & 0,8 & $-2,2$ & 3,1 \\
\hline DEU_Dessau & 4,9 & 2,5 & 2,4 & DEU_Brandenburg - Nordost & 4,8 & 2,7 & 2,1 & FIN_Etela-Suomi & $-3,3$ & $-6,3$ & 3,0 \\
\hline DEU_Brandenburg - Nordost & 4,8 & 2,7 & 2,1 & DEU_Dessau & 4,9 & 2,5 & 2,4 & SWE_ovre Norrland & 1,2 & $-1,7$ & 3,0 \\
\hline DEU_Magdeburg & 4,7 & 2,4 & 2,2 & DEU_Magdeburg & 4,7 & 2,4 & 2,2 & POL_Dolnoslaskie & 3,8 & 0,9 & 2,9 \\
\hline HUN_Del-Dunantul & 4,7 & 3,8 & 0,9 & DEU_Leipzig & 4,6 & 2,4 & 2,2 & SWE_Sydsverige & 0,0 & $-2,9$ & 2,8 \\
\hline DEU_Leipzig & 4,6 & 2,4 & 2,2 & DEU_Brandenburg - Südwest & 4,6 & 2,3 & 2,2 & SWE_ostra Mellansverige & 0,1 & $-2,5$ & 2,6 \\
\hline DEU_Brandenburg - Südwest & 4,6 & 2,3 & 2,2 & DEU_Mecklenburg-Vorpommern & 4,5 & 2,3 & 2,2 & POL_Wielkopolskie & 4,2 & 1,6 & 2,6 \\
\hline DEU_Mecklenburg-Vorpommern & 4,5 & 2,3 & 2,2 & DEU_Braunschweig & 4,2 & 2,2 & 2,1 & AUT_Vorarlberg & 1,4 & $-1,1$ & 2,5 \\
\hline NLD_Groningen & 4,4 & 3,2 & 1,2 & NLD_Friesland & 3,0 & 2,2 & 0,8 & DEU_Dessau & 4,9 & 2,5 & 2,4 \\
\hline DEU_Braunschweig & 4,2 & 2,2 & 2,1 & DEU_Weser-Ems & 4,0 & 2,1 & 1,8 & DEU_Dresden & 5,3 & 2,9 & 2,4 \\
\hline POL_Wielkopolskie & 4,2 & 1,6 & 2,6 & DEU_Halle & 3,7 & 2,0 & 1,7 & POL_Malopolskie & 3,2 & 0,8 & 2,3 \\
\hline DEU_Tubingen & 4,0 & 2,0 & 2,0 & DEU_Hannover & 3,9 & 2,0 & 1,9 & POL_Podlaskie & 3,4 & 1,0 & 2,3 \\
\hline DEU_Weser-Ems & 4,0 & 2,1 & 1,8 & DEU_Tubingen & 4,0 & 2,0 & 2,0 & POL_Pomorskie & 3,3 & 1,0 & 2,3 \\
\hline DEU_Stuttgart & 3,9 & 1,9 & 2,0 & UK_South Western Scotland & 3,0 & 2,0 & 1,1 & POL_Lódzkie & 3,2 & 0,9 & 2,3 \\
\hline DEU_Hannover & 3,9 & 2,0 & 1,9 & DEU_Dusseldorf & 3,5 & 2,0 & 1,6 & POL_Lubelskie & 3,4 & 1,1 & 2,3 \\
\hline DEU_Berlin & 3,8 & 1,7 & 2,1 & DEU_Stuttgart & 3,9 & 1,9 & 2,0 & POL_Slaskie & 3,1 & 0,9 & 2,3 \\
\hline POL_Dolnoslaskie & 3,8 & 0,9 & 2,9 & DEU_Unterfranken & 3,6 & 1,9 & 1,7 & AUT_Salzburg & 1,0 & $-1,2$ & 2,3 \\
\hline DEU_Halle & 3,7 & 2,0 & 1,7 & NLD_Zeeland & 2,9 & 1,9 & 1,1 & DEU_Magdeburg & 4,7 & 2,4 & 2,2 \\
\hline DEU_Niederbayern & 3,7 & 1,8 & 1,9 & CZE_Stredni Cechy & 1,1 & 1,8 & $-0,4$ & DEU_Thüringen & 5,0 & 2,8 & 2,2 \\
\hline
\end{tabular}

Table 1. Top $30 \mathrm{EU}$ regions ranked by foreign fragmentation.

Columns 1-3 of Table 1 show that several regions in Hungary, Germany, and Poland, have experinced a significant increase in foreign value-added contributions to their production over the period considered. Columns 4-6 show that a larger share of the value in the chains of these regions was added within the EU. However, a significant share was also added outside the EU. The production chains of these regions fragment both globally and regionally. Considering the involvement of these regions in the production chains of the automotive industry, this finding sends us back to the case studies evidence in Sturgeon et al. (2008). Columns 7-9 show a different picture. The regions with a high contribution to value-added from outside the EU are mainly located in 
northern Europe. Interestingly, the negative values reported in column 8 indicate that most of these regions have partly replaced regional with global value chains.

These results can be partly explained by the fact that here we are considering simultaneously the fragmentation of value chains for goods and services. There are two relevant aspects to underline. First, while production systems of manufactures are highly prone to production fragmentation, a large part of the services sector is made up of small domestic companies that provide services directly to domestic consumers with limited (foreign) inputs (Timmer et al., 2013). ${ }^{12}$ Second, while logistics and transportation costs may encourage the regional fragmentation of goods production (Johnson and Noguera, 2012b), the almost intangible nature of services makes their production fragmentable on a global scale at negligible cost (Fort, 2017). Therefore, in explaining the geography of fragmentation it is essential to take into account whether a region is specialised in producing services or has huge assembly plants. With this in mind, it is not surprising that the regions with a higher share of production fragmentation are the EU regions driven by the manufacturing industry, and especially the regions specialised in the automotive sector, where GVCs are very prominent (for more details on the main characteristics of industrial regions in Europe see Hoekstra, 2017). The productive structure of these regions is very connected to each other and therefore the fragmentation of production in these regions is mainly intra-EU. On the other hand, the regions specialised in services, located in small open economies (for example Ireland and Malta), and characterised by an underdeveloped manufacturing sector, tend to have a lower fragmentation of production which occurs mainly at the extra-EU level.

The significant fragmentation of the EU production network, together with the heterogeneous involvement of EU regions in GVCs at a regional or global level raise issues with important implications for the design of trade policies. The more a region is involved in global chains, the more are likely to be the losses from deglobalisation. Conversely, the more a region participates in regional chains, the more will be its resilience to deglobalisation and exposure to the interruption of EU chains.

\section{The exposure of European regions to deglobalisation}

In this section, we present the regional impact of intermediate value chains interruption. In particular, (i) we first evaluate the exposure of EU regions to the stop of intermediate input flows

\footnotetext{
${ }^{12}$ Although services are generally less produced through GVCs, the advent of digitalisation, as well as the process of specialization of companies on their core competencies, has led to a significant increase in the fragmentation of services production, especially in the financial and business activities sectors (De Backer and Miroudot, 2013).
} 
coming from and to foreign countries; (ii) next, we assume that trade in intermediate inputs is stopped only with countries outside the EU; (iii) then, we test the impact of a stop to the deliveries of intermediate inputs within the EU production network; (iv) finally, we investigate to what extent regions and countries in EU are exposed to global or regional decoupling from GVCs.

(i) Figure 3 shows the regional value-added loss from a global interruption of intermediate flows. ${ }^{13}$ The aggregate impact of this deglobalisation scenario on the EU production network would be higher than 15 percent of total value-added. This deglobalisation scenario would negatively affect the economies of all regions. However, there are sizeable differences across industries and regions. Among the most exposed activities there is the coke, petroleum, and chemicals industry located in different regions in the South-East of the UK, North-East of France, and North-West of Germany would lose almost one hundred percent of the value-added in this scenario. Particularly exposed are also the financial sectors located in the international capital hubs, Ireland and Luxembourg, as well as the agricultural sector in Inner London (UK) and in Hovedstadsreg (Denmark). On the other hand, there are industries that would hardly be affected by this hypothetical scenario; among such activities there is the hotels and restaurant industry in almost all Italian, Spanish and Greek regions would lose less than 0.1 percent. Not surprisingly, these countries are characterised by Mediterranean cuisine consisting of ingredients mostly sourced from local agriculture.

By grouping the 14 sectors of all regions, we find that the coke, petroleum, and chemicals industry would be the most affected losing around 44.2 percent of its value-added, followed by other manufacturing (37.0 percent), and electrical and transport equipment (35.5 percent). The least affected sectors would be instead construction (4.4 percent), hotels and restaurant ( 4.5 percent), and food and beverage ( 8.7 percent). The exposure of oil products to a stop in intermediate input flows is not surprising as most regions do not have access to domestic oil feedstock and need to rely on imported intermediates. Similarly, manufactured foodstuffs have relatively low foreign shares as most of the intermediates are sourced locally, which implies that these industries are relatively less exposed.

The distribution of losses among regions is very broad ranging from 6.1 (Bolzano, Italy) to 46.5 percent (Luxembourg) of the region's value-added. The largest value-added losses (higher than 20 percent) are incurred by rather small, highly integrated regions located in Ireland, Malta, Austria, Belgium, Hungary, the Netherlands, Czech Republic, Estonia, Finland, Lithuania, and in the South of Sweden. High losses are also recorded in several German regions, especially in the south

\footnotetext{
13 The data used to construct Figure 3, as well as those for the subsequent Figures 4, 5, 7, and 9, are reported in Tables B.1-B.5 of the Online Appendix B.
} 
(Darmstadt, Oberbayern, and Stuttgart would face a loss of 19 percent of value-added), in the south of Denmark, in some Polish regions, and in the South-Central of England. Conversely, the smallest losses are incurred by regions with low export and import shares and relatively small shares of intermediates in these trade flows such as many Greek, Italian, Spanish, France, and Portuguese regions. On closer inspection, the results in Figure 3 are consistent with those shown by Eppinger et al. (2021) according to which a complete shutting down of GVCs would have a negative impact on all countries of their sample.

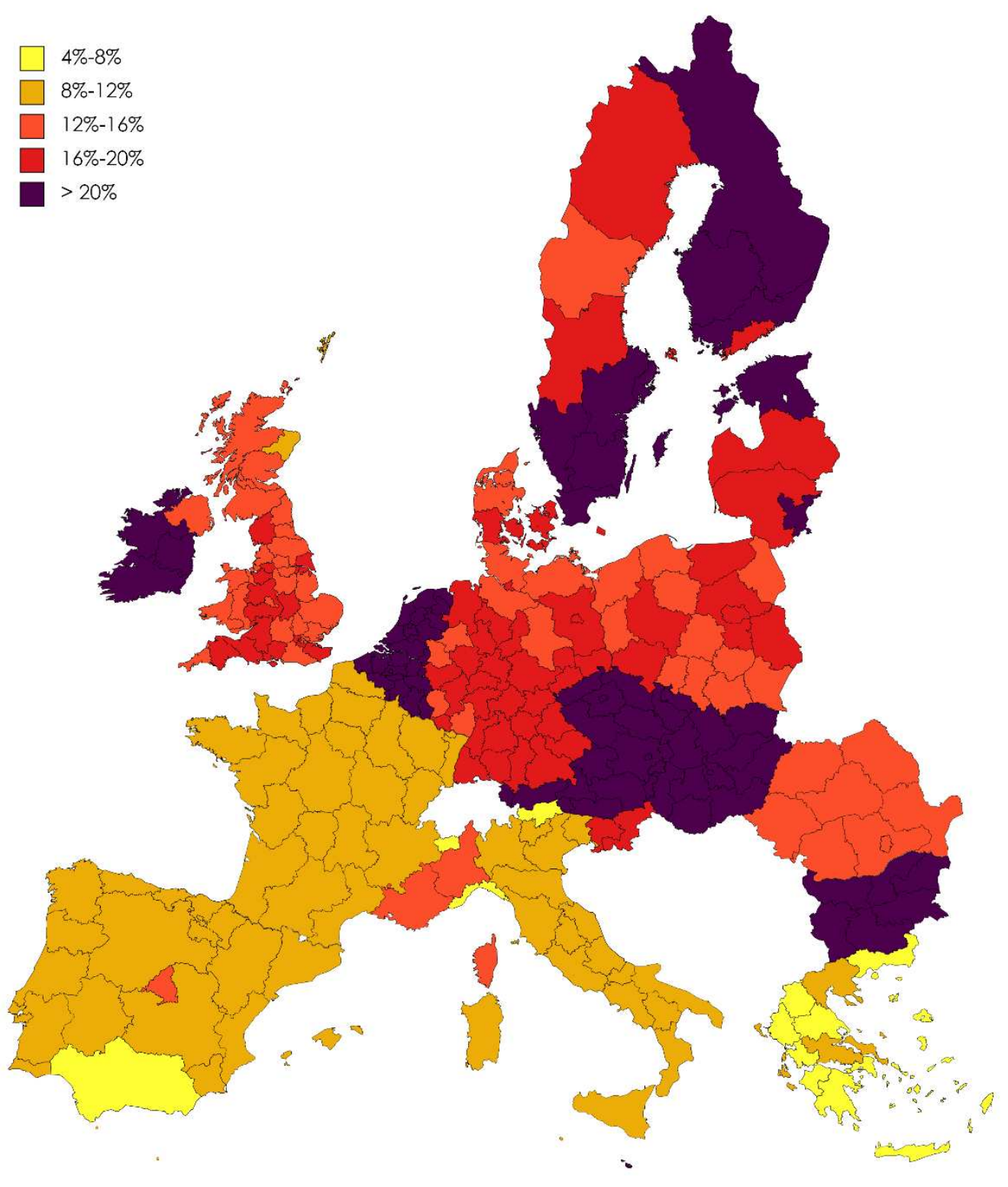

Figure 3. Regional losses in value-added shares from the total interruption of GVCs.

In particular, small highly integrated countries such as Luxembourg, Malta, or Ireland would be massive losers. The similarities with our findings are due to the fact that we analyse the same 
"world without GVCs" scenario with an approach that allows considering the indirect impacts due to input-output links and participation in GVCs. However, there are also some differences. Eppinger et al. (2021) include trade diversion in their model (we consider this hypothesis in scenario 3) and this greatly mitigates the impact on countries with developed domestic markets. Differently, in our scenario 1, we find that even large countries like Germany and the UK are at risk of deglobalisation. Furthermore, the country-level analysis by Eppinger et al. (2021) does not allow to study the heterogeneity of the impact within countries. This limits the emphasis on GVCs. Differently, in our paper, regions may show exposure to deglobalisation different to the country they belong to but similar to a neighbouring region placed in a neighbouring country. For example, Figure 3 shows that the degree of exposure for the regions Provence-Alpes-Côte d'Azur and Piemonte is similar ranging between 12-16 percent, but higher to their respective countries France and Italy.

(ii) The EU network without GVCs studied above serves as a clear benchmark, but it is highly stylized. We thus provide other two experiments. First, in Figure 4 we show the regional exposure to a zeroing of the flows of intermediates with countries outside the EU. This scenario would lead to an loss of 7.01 percent of total value-added. The most exposed industries are located in the northern regions. The coke, petroleum, and chemicals industry in Inner London (UK), the financial sector in Border Midlands and Western (IRE), and the electrical and transport equipment in Ita-Suomi (FIN), would lose more than 70 percent of value-added. The northern regions bear large losses, with Ireland, Finland, Sweden, Denmark, the Baltic countries, and some UK regions facing over 10 percent losses. Conversely, Central Europe appears less vulnerable to this scenario. For example, all the German regions highly impacted in the previous scenario now would face losses smaller than 7 percent. The same holds for Poland and the Czech Republic, while Hungary still faces significant losses of about 13 percent.

(iii) As a further exercise, we evaluate the impact of decoupling from EU GVCs. The interruption of the EU supply chains would entail an aggregate loss (about 8 percent) greater than the interruption of the extra-EU chains. However, as depicted in Figure 5, compared to the previous scenarios with losses spread across many regions, here the losses seem to be concentrated in the Central-Eastern regions. The losses in the German, Austrian, Belgian, Dutch, Hungarian, Czechoslovakian, and Slovakian regions account for 53.4 percent of total losses. Several regions in Belgium, the Netherlands, and the Czech Republic are exposed to almost 20 percent losses. Particularly hit also southern Germany, the powerhouse of EU manufacturing, especially in the automotive and machinery industry. If we exclude the Central-Eastern regions, all the other regions would face less than 10 percent losses. 
It also worth noting that the degree of exposure of a region is similar to the neighbouring ones, beyond national borders, which suggests that gravity plays an important role and that neighbouring regions are likely to belong to the same value chains (Johnson and Noguera, 2012b). In accordance with the results shown in the previous section, Figures 3, 4, and 5 suggest the presence of three main regional value chains. The Central-Eastern bloc, highly integrated within the interregional production network, the Northern bloc, mainly integrated with countries outside the EU, and the Southern bloc, less dependent on regional and global supply chains.

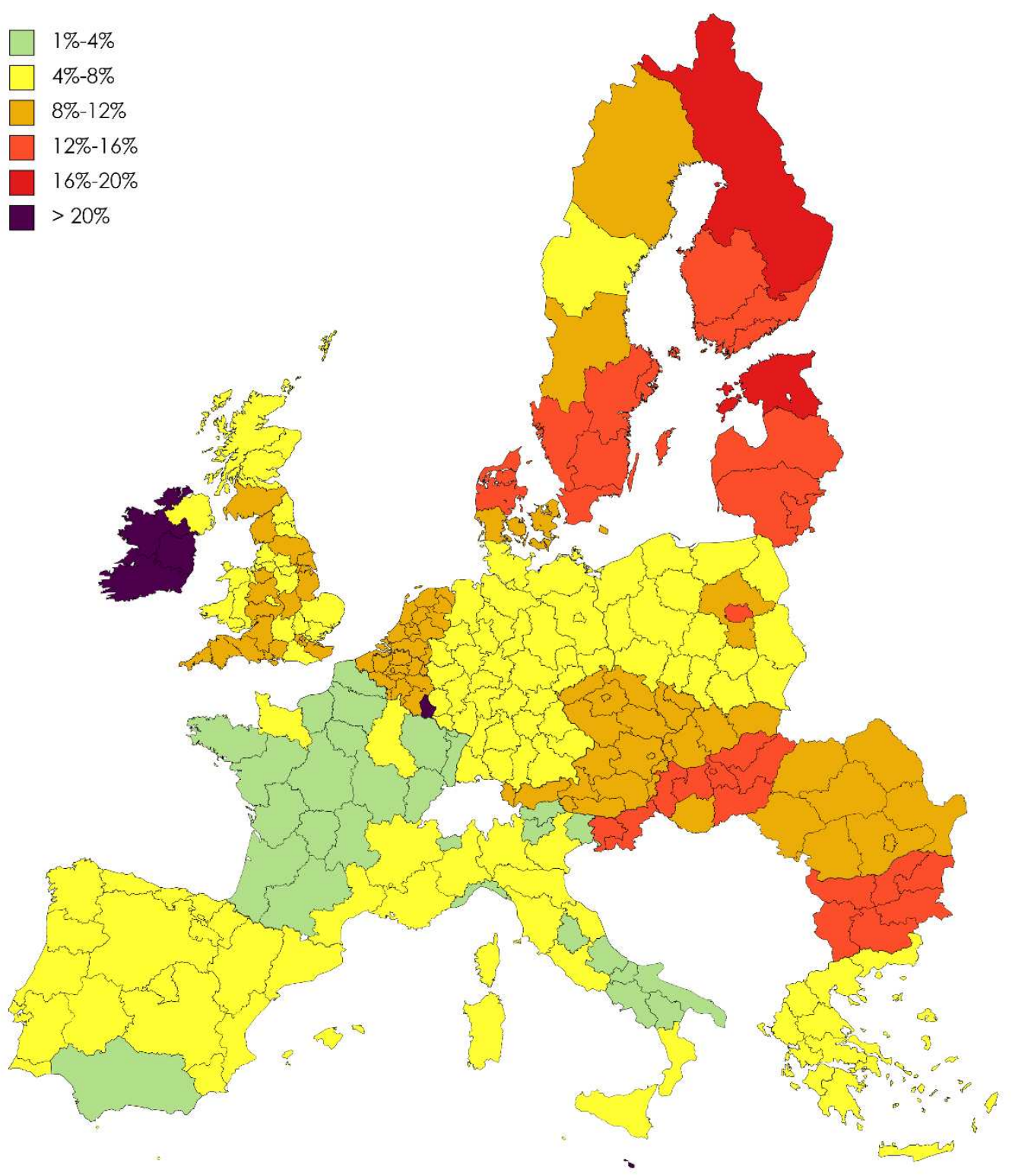

Figure 4. Regional losses in value-added shares from the interruption of extra-EU GVCs. 


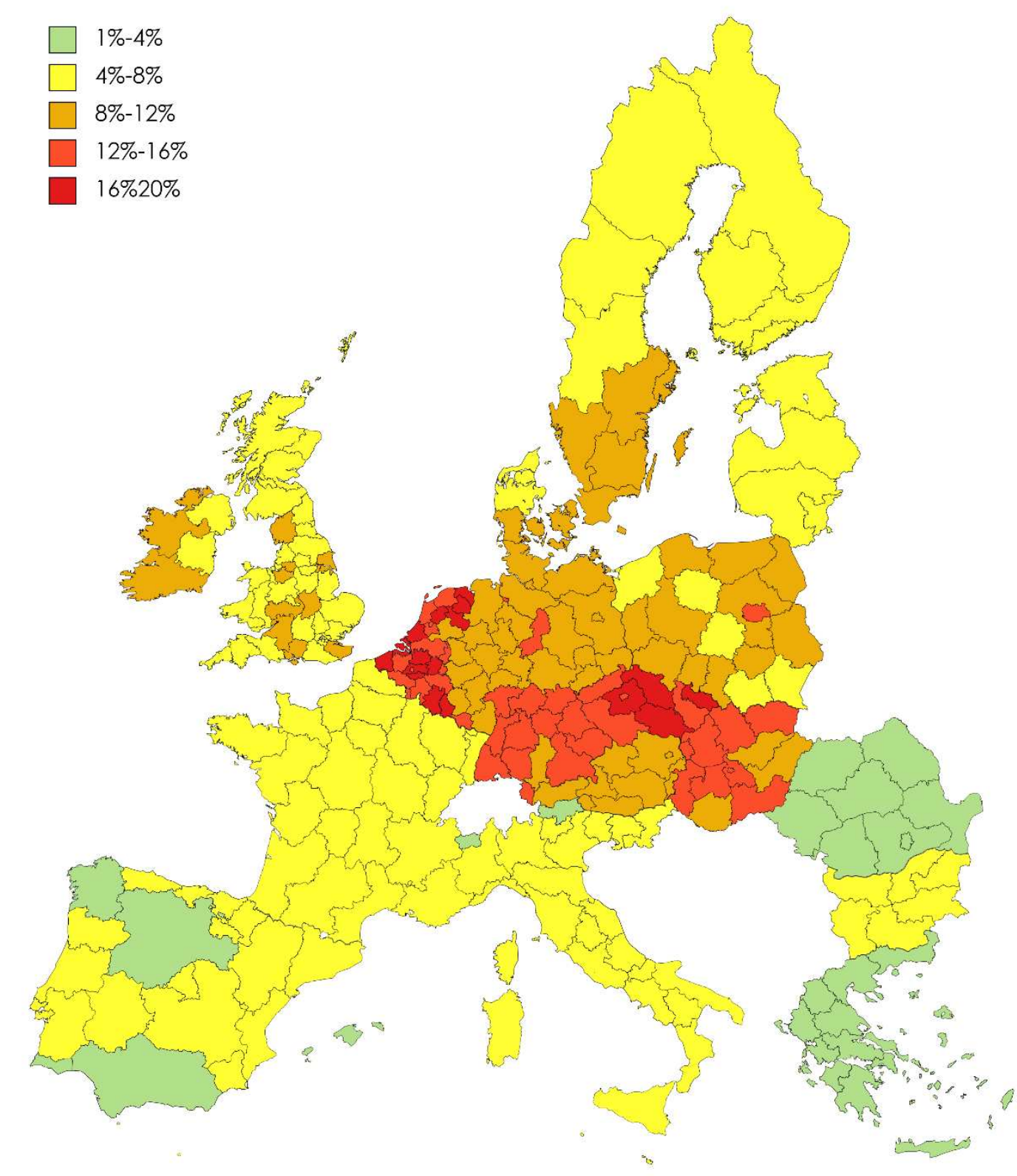

Figure 5. Regional losses in value-added shares from the interruption of EU GVCs.

(iv) This latter result is corroborated by the results in Figure 6 that shows the national levels of value-added losses due to the decoupling from Extra-EU and EU value chains. As can be seen, the regional differences are also reflected in the national levels of exposure. Countries with production processes fragmented mainly outside the EU, such as northern countries, are more vulnerable to an interruption of value chains with extra-EU countries. On the other hand, countries that mainly rely on interregional value chains, such as Germany and its trade satellites, are more exposed to a stop of regional value chains. 


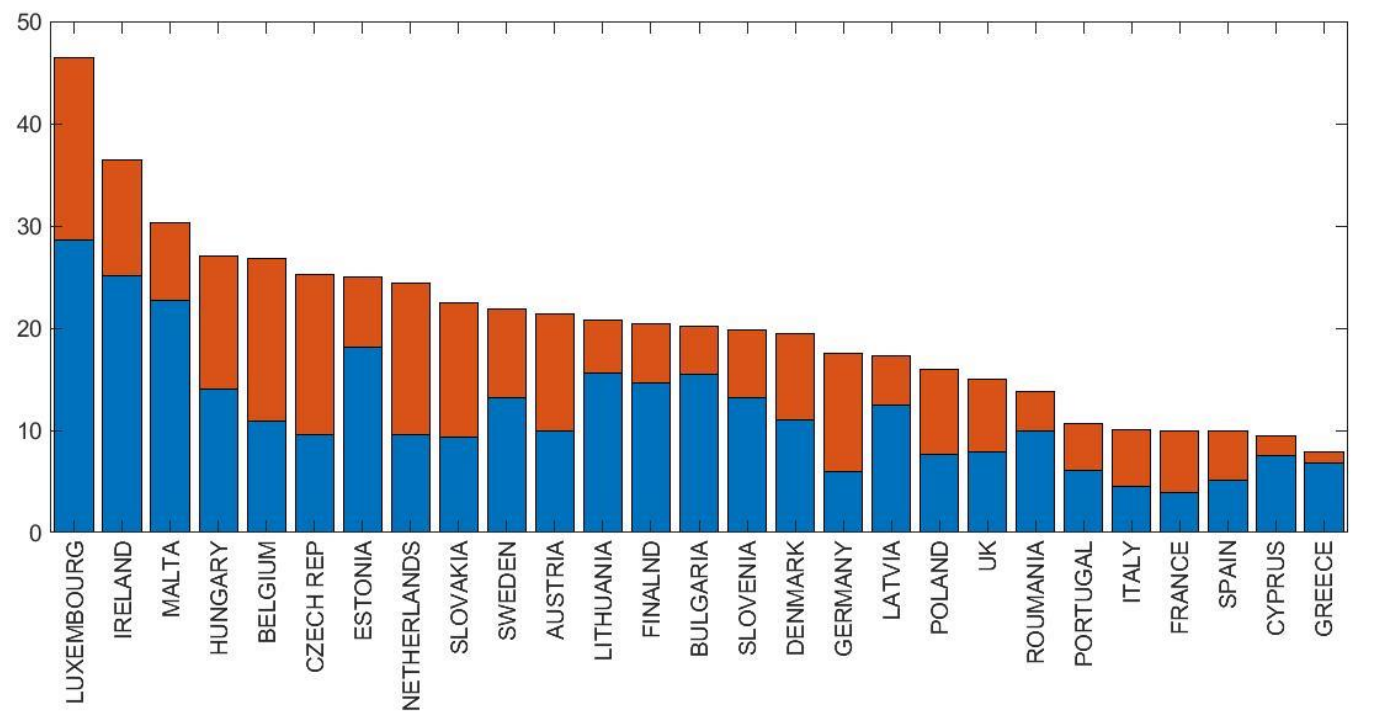

Figure 6. Country losses in value-added shares from the interruption of extra-EU and EU GVCs.

\section{The economic implications of a return to a less integrated world}

The extensive empirical literature on the globalisation-led growth nexus supports the view that the increase in international trade coincided with an increase in world GDP (see, among many others, Dreher, 2006). However, as shown in the literature on the backlash of globalisation (Colantone et al., 2021), the gains from international trade are unequally distributed and globalisation has created winners and losers.

In this section, we investigate if the same would hold true also for deglobalisation. Specifically, we aim to answer the following questions. What would be the economic impact of a return to a less integrated trade? Would the sign and degree of this impact be the same for all EU regions and countries in the world? To answer these questions, we test the impact on current value-added of a back to the past scenario in which the production and trade in intermediates take place according to the patterns of the past. More precisely, we draw on the literature on structural change in inputoutput systems (Sonis et al., 1996) and measure to what extent the value-added in 2010 would change if production took place with the input coefficients of 2000.

Our findings indicate that a return to the old production schemes and trade patterns would generate a global loss of about 3 percent of total value-added. However, while the world economy would shrink, the aggregate variation of the EU value-added would be positive, although the size of the change is small (around 0.3 percent). 


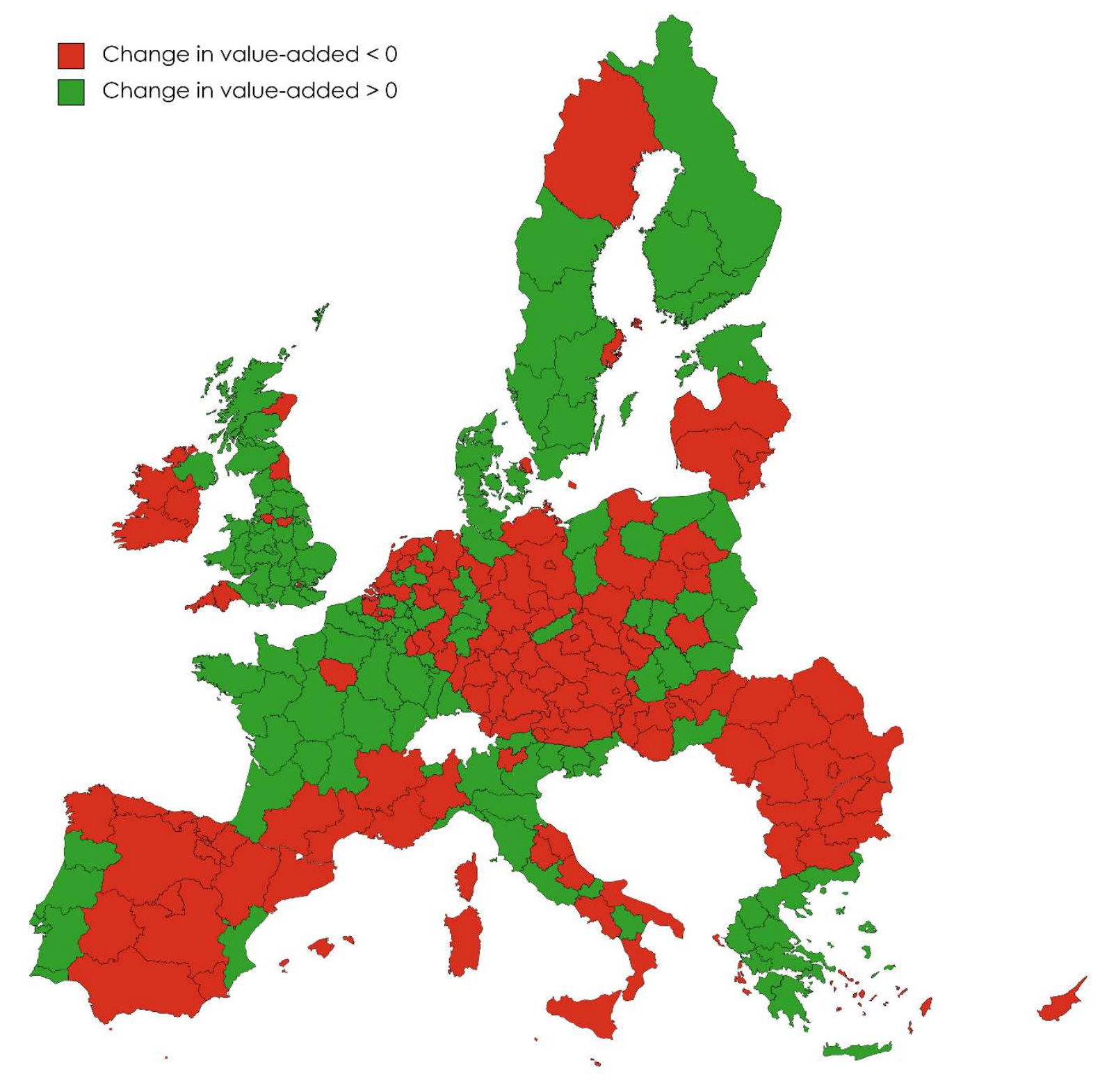

Figure 7. Regional change in value-added shares in the back to the past scenario.

This asymmetry is also found at the industry and regional level. While sectors such as textiles and leather (26.9 percent), agriculture (14.8 percent), electrical and transport equipment (12.8 percent) would gain from a return to the past, other sectors, as mining, quarrying, and energy (-8.2 percent), real estate and business activities (-7.1 percent), and construction (-1.4 percent), would suffer significant losses. Figure 7 displays the regional change in value-added shares in the back to the past scenario for the EU regions in the form of a map. The grey regions are those that would suffer a reduction in value-added, whereas the white regions would experience a positive change in valueadded. As we can see, there are sizable differences across regions and within the same countries. Ireland, and almost all regions in Spain, Germany, and Central-Eastern Europe, would suffer output 
losses. Conversely, with the only exception of Inner London, and a few regions in the West-South and in the Centre-North, all regions in UK would gain from a back to the past scenario. ${ }^{14}$ A similar pattern emerges in Denmark, Estonia, Finland, Greece, Portugal, and Sweden. Italy and France show mixed results. The less industrialised southern regions of both countries might have benefited

\begin{tabular}{|c|c|c|c|}
\hline \multicolumn{2}{|c|}{$\begin{array}{c}\text { Top } 30 \text { regions ranked by } \\
\text { negative change in value-added }\end{array}$} & \multicolumn{2}{|c|}{$\begin{array}{c}\text { Top } 30 \text { regions ranked by } \\
\text { positive change in value-added }\end{array}$} \\
\hline & (1) & & (2) \\
\hline & Change & & Change \\
\hline & in & & in \\
\hline Country Code_Region & value-added & CountryCode_Region & value-added \\
\hline ESP_Pais Vasco & $-36,1$ & ESP_Comunidad Valenciana & 54,0 \\
\hline HUN_Kozep-Magyarorszag & $-16,0$ & GRC_Peloponnisos & 24,4 \\
\hline NLD_Groningen & $-11,4$ & FIN_Ita-Suomi & 18,8 \\
\hline ESP_Comunidad de Madrid & $-11,0$ & GRC_Kentriki Makedonia & 14,6 \\
\hline CZE_Praha & $-11,0$ & GRC_Sterea Ellada & 13,9 \\
\hline IRE_Border Midlands & $-11,0$ & GRC_Ipeiros & 13,4 \\
\hline POL_Mazowieckie & $-11,0$ & GRC_Thessalia & 11,6 \\
\hline IRE_Southern and Eastern & $-10,5$ & UK_Outer London & 11,6 \\
\hline MLT_MLT & $-10,5$ & ITA_Lombardia & 11,5 \\
\hline DEU_Dessau & $-8,5$ & UK_Bedfordshire Hertfordshire & 11,1 \\
\hline BEL_Prov. Brabant Wallon & $-8,3$ & UK_West Midlands & 10,0 \\
\hline LTU_Lietuva & $-8,1$ & UK_South Western Scotland & 9,5 \\
\hline ITA_Campania & $-8,1$ & UK_East Wales & 9,3 \\
\hline ESP_Region de Murcia & $-8,0$ & SWE_Småland med oarna & 9,0 \\
\hline NLD_Flevoland & $-7,6$ & GRC_Dytiki Ellada & 9,0 \\
\hline ESP_Cataluna & $-7,4$ & UK_Surrey East and West Sussex & 8,4 \\
\hline DEU_Magdeburg & $-6,9$ & UK_Herefordshire Worcestershire & 8,2 \\
\hline CZE_Stredni Cechy & $-6,8$ & UK_West Wales and The Valleys & 8,0 \\
\hline DEU_Brandenburg - Nordost & $-6,7$ & ITA_Veneto & 7,7 \\
\hline POL_Dolnoslaskie & $-6,3$ & UK_Kent & 7,6 \\
\hline CZE_Jihovychod & $-6,0$ & ITA_Emilia-Romagna & 7,5 \\
\hline NLD_Zeeland & $-5,9$ & FIN_Lansi-Suomi & 7,0 \\
\hline ESP_La Rioja & $-5,9$ & SWE_Sydsverige & 6,9 \\
\hline DEU_Thüringen & $-5,8$ & SWE_Norra Mellansverige & 6,8 \\
\hline DEU_Leipzig & $-5,7$ & GRC_Voreio Aigaio & 6,8 \\
\hline ITA_Sardegna & $-5,7$ & UK_Lancashire & 6,7 \\
\hline ESP_Galicia & $-5,6$ & UK_Tees Valley and Durham & 6,6 \\
\hline DEU_Brandenburg - Südwest & $-5,5$ & SVK_Východne Slovensko & 6,4 \\
\hline DEU_Dusseldorf & $-5,4$ & FIN_Etela-Suomi & 6,2 \\
\hline DEU_Dresden & $-5,1$ & GRC_Kriti & 5,8 \\
\hline
\end{tabular}

Table 2. Top 30 regions ranked by negative and positive change in value-added.

\footnotetext{
${ }^{14}$ This result is also interesting for the Brexit debate.
} 
from the delivery of intermediate inputs from international trade; therefore, a back to the past scenario could have negative effects on production. Conversely, the more industrialised northern regions of these countries might have suffered international competition, especially in manufacturing, and may gain from a return to the past.

The map in Figure 7 does not allow us to distinguish the degree of the impact of the back to the past scenario. Hence, in Table 2 we show the top 30 regions classified according to the negative (column 1) and positive (column 2) changes in value-added. ${ }^{15}$ An indication about the asymmetry of the impact that a return to the past would have on EU economies is provided by the first row of columns 1 and 2. As we can see, Spain simultaneously hosts the most negatively (Pais Vasco) and positively (Comunidad Valenciana) affected regions. The largest reductions in value-added take place in some Spanish regions (especially the territories around Barcelona and Madrid), and the regions located along the Central-Eastern axis, from the Netherlands to Hungary via Germany, Poland, and the Czech Republic. Conversely, the regions showing the larger positive change in value-added are located in the UK, Greece, Northern Italy, Finland, and Sweden. ${ }^{16}$

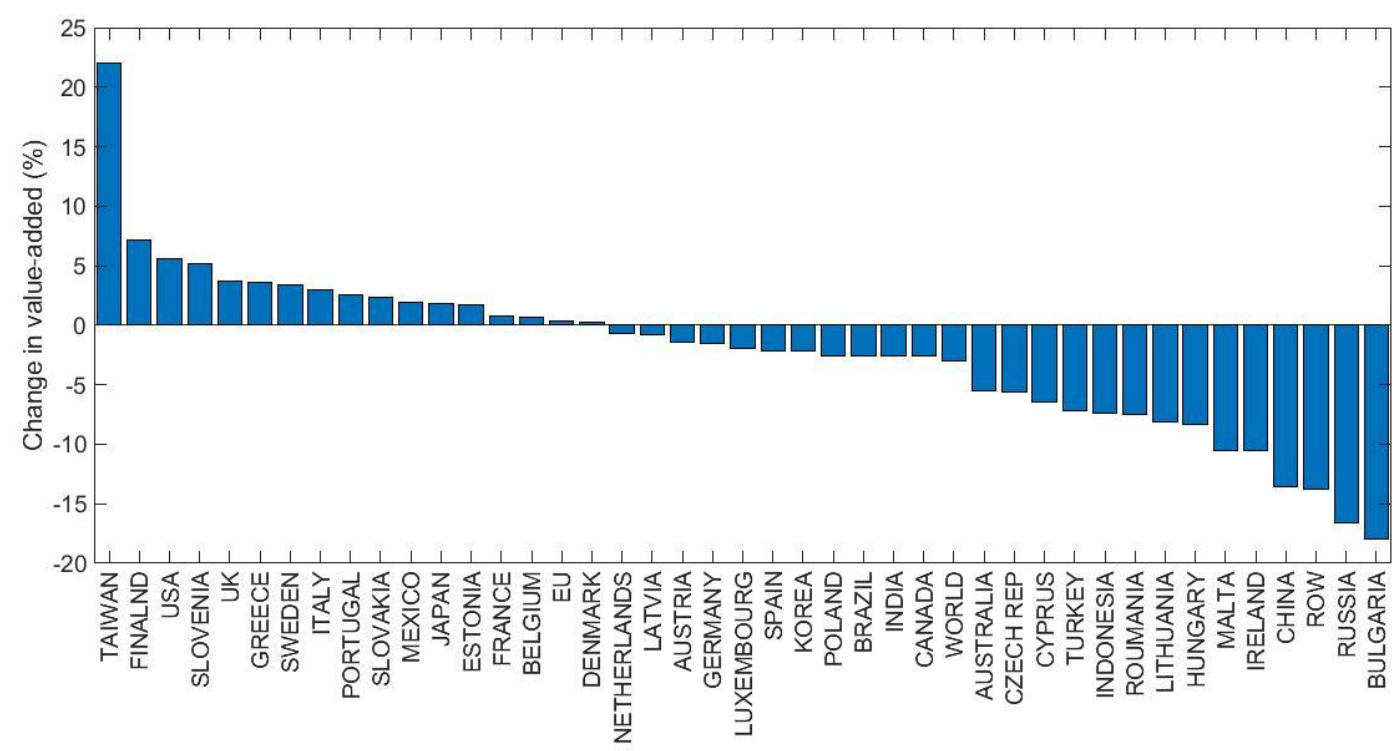

Figure 8. Country change in value-added shares in the back to the past scenario.

\footnotetext{
${ }^{15}$ The results for all regions are reported in Table B.4 of the Online Appendix B.

${ }^{16}$ By inspecting the region-sector level, we find an asymmetric impact also within sectors and regions. For example, the positive change recorded by the EU textiles and leather sector comes at the expense of a big loss (close to 30 percent) suffered by the same Chinese industry. Further, while at the region-sector level the largest value-added losses (higher than 60 percent) are incurred by the coke, petroleum, and chemicals industry in Praha (CZE), Dusseldorf (DEU), Lodzkie (POL), and Pais Vasco (ESP), at the aggregate level this sector would gain about 5 percent of valueadded. The same is true if we look at the losses and gains of industries within the regions. For example, Pais Vasco would lose 36.1 percent of its value-added. However, in this region the agriculture and textiles and leather sectors would gain more than 20 percent of value-added.
} 
Our findings suggest that a scenario of deglobalisation intended as a return to the past, would create winners and losers. This evidence holds at the industry, region, and country level. To have a better understanding of the winners and losers from deglobalisation at the aggregate level, Figure 8 show the change in value-added by countries. As we can see, the main losers from deglobalisation are the countries that largely benefited from trade openness, namely export led economies, such as Germany, and emerging countries as China. On the other hand, among the main winners from deglobalisation we find many strong and developed economies such as the US, the UK, Italy, Japan, and France. It should be noted that our results could also be read in reverse. The winners from deglobalisation are likely to be the losers from globalisation. In this sense, our findings seem to be in line with the backlash against globalisation and the surge of nationalism that has recently occurred in these countries (see the Trump's protectionist agenda in US, the vote for Brexit in the UK, and the rise of nationalist parties in France and Italy).

\section{The case for GVCs Europeanisation}

In this section, we employ the global hypothetical extraction method (Dietzenbacher et al., 2019; Giammetti, 2020) to investigate the economic impact of a GVCs Europeanisation. Specifically, we assume that EU regions totally replace the intermediate inputs imported from extra-EU countries with the same intermediate inputs from other EU countries. We do not allow for domestic import substitution. ${ }^{17}$ This means that EU regions replace extra-EU intermediates exclusively with goods and services produced in regions of other EU countries. This assumption is in line with the 'love of variety' theory (Bernard et al., 2007) and the conventional Ricardo-Heckscher-Ohlin 'gains from trade' theory.

Our findings indicate that replacing extra-EU GVCs with intra-EU GVCs would have almost no impact on the world economy ( 0.1 percent). This is not surprising since according to the global hypothetical extraction method, what EU regions gain from import substitution is lost by non-EU countries that stop exporting intermediates to Europe. Therefore, rather than looking at the aggregate impact, it is more interesting to study how these losses and gains are distributed between EU regions and non-EU countries. The distribution of losses and gains indicates, to some extent, which regions would benefit most from a strengthening of the EU production network and which extra-EU countries would suffer most from a Europeanisation of EU GVCs.

\footnotetext{
${ }^{17}$ We follow closely the standard global hypothetical extraction method developed in Dietzenbacher et al. (2019) that does not allow the substitution of imported intermediate inputs with domestic goods and services. However, allowing for such substitution (as in Giammetti, 2020) does not change our results (details are available upon request).
} 


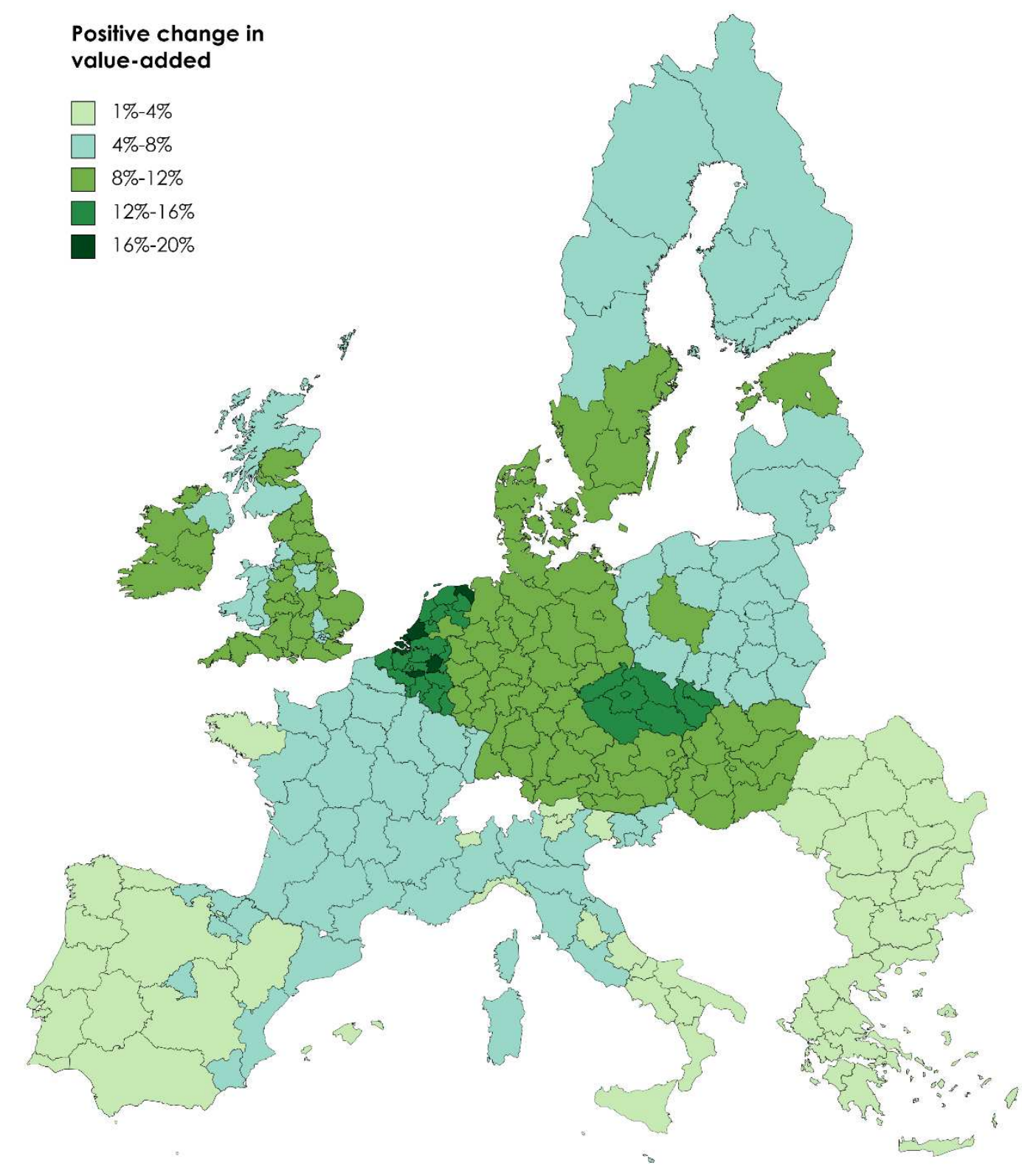

Figure 9. Positive regional change in value-added shares in the GVCs Europeanisation scenario.

Figure 9 shows the positive change in value-added that would occur in the EU regions following the Europeanisation of EU production chains. The regions that in relative terms would mostly benefit from a strengthening of the EU chains are located in Central-Eastern Europe (especially in the Netherlands, Belgium, and the Czech Republic), in some regions of the Scandinavian Peninsula (Estonia, Denmark, and the South of Sweden), in Ireland, and in the UK. In relative terms, southern Europe, France, Poland, Finland, and the remaining Baltic countries appear to be less affected by a Europeanisation of value chains. Interestingly, most of the top winner regions in this scenario are among the top losers of the back to the past scenario. In this sense, our results suggest the presence of two classes of regions with conflicting interests: those that would 
benefit from a return to the past, when the fragmentation of production was more limited, and the others that would instead gain from a greater integration of EU production chains. A special case is represented by the UK. As we have seen in the previous section, almost all regions of the UK would benefit from a return to past production patterns; and this result could partly explain the discontent that resulted in the Brexit vote. However, as shown in Figure 9, most UK regions would see an increase of their value-added by more than 12 percent following a strengthening of input-output relationships within the EU production network. Therefore, according to our results, the Brexit vote may not have been the most cost-effective solution for the UK.

The bar graph in Figure 10 displays the country change in value-added that occurs as a result of the Europeanisation of GVCs. As we can see, the differences at regional level from a strengthening of the EU production network also appear at the national one. Germany and its neighbours would experience an increase of value-added of more than 10 percent. The effect for Ireland, the UK, and Scandinavia would also be quite positive, while the change in value-added would not exceed 5 percent for the other EU countries. It is also worth noting that, outside the EU, Russia appears to be very affected by a GVCs Europeanisation with a negative change in value-added of about 13 percent. All the other countries would suffer limited losses in value-added ranging from 0.6 (Japan) to 3.0 percent (Turkey).

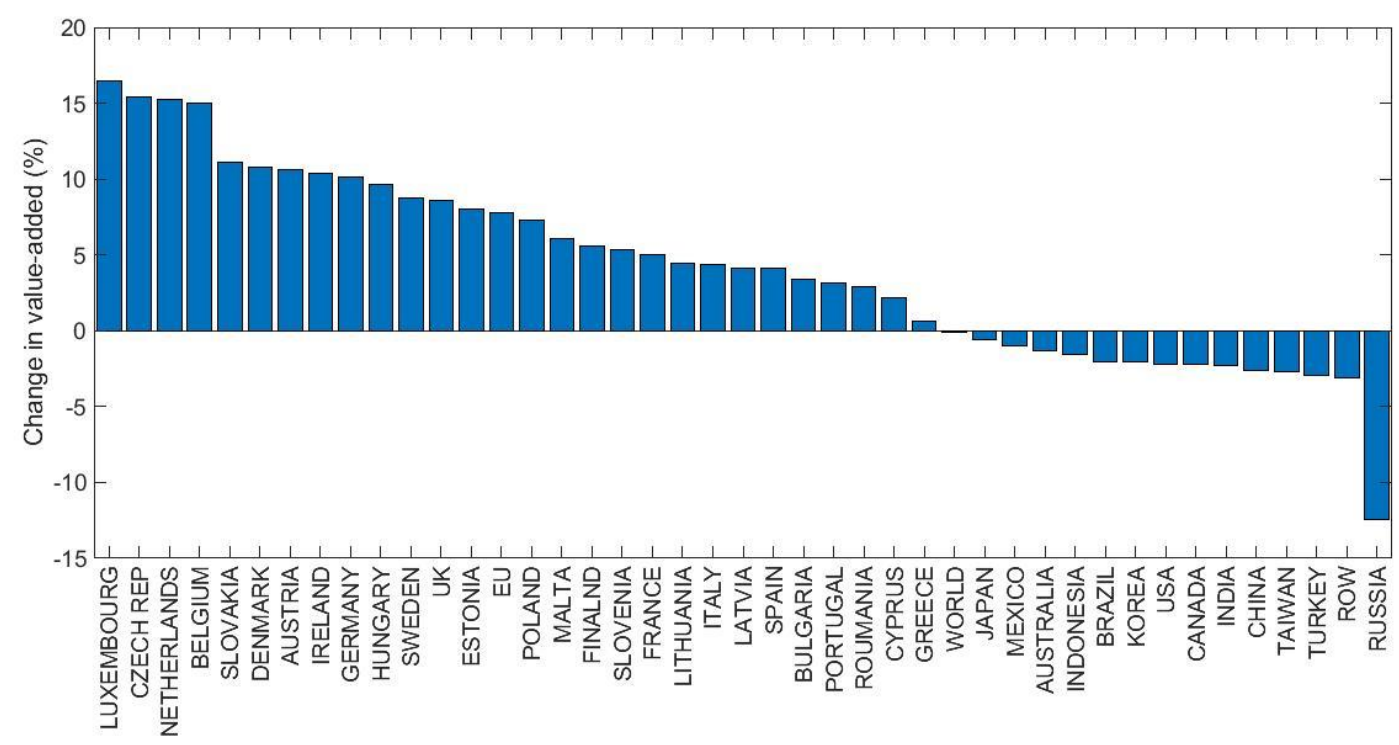

Figure 10. Country change in value-added shares in the GVCs Europeanisation scenario. 


\section{Conclusion}

This paper contributes to the debate on changing geographies of value chains and production networks in a deglobalised world by studying the impact of three different kind of deglobalisation scenarios on EU regional economies. Using an input-output approach in a GVCs framework, we have first supported the relevance of our research question by showing that EU regional production network has become increasingly fragmented since 2000 and that such fragmentation has occurred mainly at EU level, although the trend towards production fragmentation outside the EU shows a faster pattern.

The results of our scenario analysis have shown that the degree of exposure to deglobalisation is similar in neighbouring regions beyond national borders and identified three main regional value chains. The Central-Eastern bloc, highly integrated within the interregional production network, the Northern bloc, mainly integrated with countries outside the EU, and the Southern bloc, that is less dependent on regional and global supply chains.

We also found that deglobalisation might generate winners and losers. The simulation of a scenario involving a return of productions and trade patterns scheme to the year 2000 reveals an asymmetric impact on industries, regions, and countries. In aggregate terms, the main losers from deglobalisation are the countries that largely benefited from trade openness, namely export led economies and emerging countries such as Germany and China, respectively. On the other hand, among the main winners from deglobalisation, we found many strong and developed economies such as the US, the UK, Italy, Japan, and France. Moreover, our analysis highlighted the presence of two categories of regions that may have conflicting interests, namely regions that would benefit from a return to the past when the fragmentation of production was more limited, and others that would instead gain from the Europeanisation of GVCs. 


\section{References}

Antràs, P. (2021) De-Globalisation? Global Value Chain in the post-COVID-19 Age. National Bureau of Economic Research, No. 28115. https://doi.org/10.3386/w28115

Baldwin, R. and Evenett, S. J. (2020) COVID-19 and Trade Policy: Why Turning Inward Won't Work. CEPR Press.

Baldwin, R., and Lopez-Gonzalez, J. (2015) Supply-chain Trade: A Portrait of Global Patterns and Several Testable Hypotheses. The World Economy, 38(11), 1682-1721. https://doi.org/10.1111/twec.12189

Bernard, A. B., Jensen, J. B., Redding, S. J., and Schott, P. K. (2007) Firms in International Trade. Journal of Economic Perspectives, 21(3), 105-130. https://doi.org/10.1257/jep.21.3.105

Bonadio, B., Huo, Z., Levchenko, A. A., and Pandalai-Nayar, N. (2020) Global Supply Chains in the Pandemic. National Bureau of Economic Research, No. 27224. https://doi.org/10.3386/w27224

Bonet-Morón, J., Ricciulli-Marín, D., Pérez-Valbuena, G.J., Galvis-Aponte, L.A., Haddad, E. A., Araújo, I., and Perobelli, F. S. (2020) Regional economic impact of COVID-19 in Colombia: An input-output approach. Regional Science Policy \& Practice, 12, 1123-1150. https://doi.org/10.1111/rsp3.12320

Brakman, S., Garretsen H., and Kohl, T. (2021) EXITitis in the UK: Gravity Estimates in the Aftermath of Brexit. CESifo Working Paper Series, No. 9292, CESifo.

Brakman, S., Garretsen, H., and van Marrewijk, C. (2015) Regional resilience across Europe: on urbanisation and the initial impact of the Great Recession. Cambridge Journal of Regions, Economy and Society, 8(2), 225-240. https://doi.org/10.1093/cjres/rsv005

Brakman, S., Garretsen, H., and van Witteloostuijn, A. (2020) The turn from just-in-time to just-incase globalization in and after times of COVID-19: An essay on the risk re-appraisal of borders and buffers. Social Sciences \& Humanities Open, 2(1), 100034.

Carrascal Incera, A., Kitsos, A., and Gutierrez Posada, D. (2021) Universities, students and regional economies: a symbiotic relationship? Regional Studies. https://doi.org/10.1080/00343404.2021.1925236

Chen, W., Los, B., McCann, P., Ortega-Argilés, R., Thissen, M., and Oort, F. van. (2018) The continental divide? Economic exposure to Brexit in regions and countries on both sides of The Channel. Papers in Regional Science, 97(1), 25-54. https://doi.org/10.1111/pirs.12334

Colantone, I., Ottaviano, G. I., and Stanig, P. (2021) The backlash of globalization. CEPR Discussion Paper, No. 16521. 
De Backer, K. and Miroudot, S. (2013) Mapping Global Value Chains. OECD Trade Policy Papers, No. 159, OECD Publishing, Paris, https://doi.org/10.1787/5k3v1trgnbr4-en.

Dedrick, J., Kraemer, K. L., and Linden, G. (2010) Who profits from innovation in global value chains? A study of the iPod and notebook PCs. Industrial and Corporate Change, 19(1), 81116. https://doi.org/10.1093/icc/dtp032

De Ruyter, A., Martin, R., and Tyler, P. (2021) Geographies of discontent: sources, manifestations and consequences. Cambridge Journal of Regions, Economy and Society, 14(3), 381-393, https://doi.org/10.1093/cjres/rsab025

Díaz-Lanchas, J., Sojka, A. and Di Pietro, F. (2021) Of losers and laggards: the interplay of material conditions and individual perceptions in the shaping of EU discontent. Cambridge Journal of Regions, Economy and Society, 14(3), 395-415.

Dietzenbacher, E., and Lahr, M. L. (2013) Expanding Extractions. Economic Systems Research, 25(3), 341-360. https://doi.org/10.1080/09535314.2013.774266

Dietzenbacher, E., van Burken, B., and Kondo, Y. (2019) Hypothetical extractions from a global perspective. Economic Systems Research, 31(4), 505-519. https://doi.org/10.1080/09535314.2018.1564135

Dijkstra, L., Poelman, H., and Rodríguez-Pose, A. (2020) The geography of EU discontent. Regional Studies, 54(6), 737-753, https://doi.org/10.1080/00343404.2019.1654603

Di Stefano, E. (2021) COVID-19 and global value chains: the ongoing debate. Bank of Italy Occasional Papers, No. 618.

Dreher, A. (2006) Does globalization affect growth? Evidence from a new index of globalization. Applied Economics, 38(10), 1091-1110. https://doi.org/10.1080/00036840500392078

Eppinger, P., Felbermayr, G. J., Krebs, O., and Kukharskyy, B. (2021) Decoupling Global Value Chains. CESifo Working Paper, No. 9079.

Feenstra, R. C., and Hanson, G. H. (1996) Globalization, Outsourcing, and Wage Inequality. American Economic Review, 86(2), 240-245.

Feenstra, R. C., and Hanson, G. H. (1999) The Impact of Outsourcing and High-Technology Capital on Wages: Estimates for the United States, 1979-1990*. Quarterly Journal of Economics, 114(3), 907-940. https://doi.org/10.1162/003355399556179

Ferraresi, T., Ghezzi, L., Vanni, F., Guerini, M., Lamperti, F., Reissl, S., Fagiolo, G., Caiani, A., Napoletano, M., and Roventini, A. (2021) On the economic and health impact of the Covid19 shock on Italian regions: A value-chain approach. LEM Working Paper Series - 2021/10.

Fort, T. C. (2017) Technology and Production Fragmentation: Domestic versus Foreign Sourcing. The Review of Economic Studies, 84(2), 650-687. https://doi.org/10.1093/restud/rdw057 
Gereffi, G. (2020) What does the COVID-19 pandemic teach us about global value chains? The case of medical supplies. Journal of International Business Policy, 3, 287-301. https://doi.org/10.1057/s42214-020-00062-w

Giammetti, R. (2020) Tariffs, domestic import substitution and trade diversion in input-output production networks: An exercise on Brexit. Economic Systems Research, 32(3), 318-350. https://doi.org/10.1080/09535314.2020.1738347

Giammetti, R., Papi, L., Teobaldelli, D., and Ticchi, D. (2020a) The Italian value chain in the pandemic: the input-output impact of Covid-19 lockdown. Journal of Industrial and Business Economics, 47, 483-497. https://doi.org/10.1007/s40812-020-00164-9

Giammetti, R., Russo, A., and Gallegati, M. (2020b) Key sectors in input-output production networks: An application to Brexit. The World Economy, 43(4), 840-870. https://doi.org/10.1111/twec.12920

Gong, H., Hassink, R., Tan, J. and Huang, D. (2020) Regional Resilience in Times of a Pandemic Crisis: The Case of COVID-19 in China. Tijdschrift voor Economische en Sociale Geografie, 111(3), 497-512. https://doi.org/10.1111/tesg.12447

Guan, D., Wang, D., Hallegatte, S., Davis, S. J., Huo, J., Li, S., Bai, Y., Lei, T., Xue, Q., Coffman, D., Cheng, D., Chen, P., Liang, X., Xu, B., Lu, X., Wang, S., Hubacek, K., and Gong, P. (2020) Global supply-chain effects of COVID-19 control measures. Nature Human Behaviour, 4(6), 577-587. https://doi.org/10.1038/s41562-020-0896-8

Haddad, E. A., Perobelli, F. S., Araújo, I. F., Bugarin, K. S. S. (2021) Structural propagation of pandemic shocks: an input-output analysis of the economic costs of COVID-19. Spatial Economic Analysis, 16(3), 252-270, https://doi.org/10.1080/17421772.2020.1844284

Hassink, R. (2010) Regional resilience: a promising concept to explain differences in regional economic adaptability? Cambridge Journal of Regions, Economy and Society, 3(1), 45-58. https://doi.org/10.1093/cjres/rsp033

Hassink, R. and H. Gong (2020) Regional Resilience. In: Kobayashi, A., Boyle M., Castree, N., Collins, F., Crampton J., de Leeuw, S., Ho, E., Luginah, I., Maharaj, B., and J. Tyner (eds.) International Encyclopedia of Human Geography. Oxford: Elsevier.

Henderson, J., Dicken, P., Hess, M., Coe, N., and Yeung, H. W.-C. (2002) Global production networks and the analysis of economic development. Review of International Political Economy, 9(3), 436-464. https://doi.org/10.1080/09692290210150842

Hillebrand, E. E. (2010) Deglobalization scenarios: Who wins? Who loses? Global Economy Journal, 10(2). https://doi.org/10.2202/1524-5861.1611 
Hobolt, S. B. and de Vries, C. E. (2016) Public support for European integration. Annual Review of Political Science, 19, 413-432.

Hoekstra, M.S. (2017) Economic performance and place-based characteristics of industrial regions in Europe. Comparative cross-national report. Technical Report. Bright Future for Black Towns project. Available at www.jpi-urbaneurope.eu/project/bright-future/

Hubert, E. (2019) Extraction-cum-substitution: A KISS approach to mapping the impacts of bilateral trade conflicts. MPRA Paper, No. 95162, University Library of Munich, Germany.

Hummels, D., Ishii, J., and Yi, K.-M. (2001) The nature and growth of vertical specialization in world trade. Journal of International Economics, 54(1), 75-96. https://doi.org/10.1016/S00221996(00)00093-3

Hummels D., Rapoport, D., and Kei-Mu Yi. (1998) Vertical specialization and the changing nature of world trade. Economic Policy Review, Federal Reserve Bank of New York, 4, 79-99.

IJtsma, P., and Los, B. (2020) UK Regions in Global Value Chains. Economic Statistics Centre of Excellence (ESCoE) Discussion Papers ESCoE DP-2020-08.

Irwin, D. (2020) Free Trade Under Fire. Princeton: Princeton University Press, 5th edition.

Isard, W. (1951) Interregional and Regional Input-Output Analysis: A Model of a Space-Economy. The Review of Economics and Statistics, 33(4), 318-328. https://doi.org/10.2307/1926459

James, H. (2017) Deglobalization as a Global Challenge. CIGI Papers No. 135, Centre for International Governance Innovation: Waterloo (ON).

Johnson, R. C. (2018) Measuring Global Value Chains. Annual Review of Economics, 10(1), 207236. https://doi.org/10.1146/annurev-economics-080217-053600

Johnson, R. C., and Noguera, G. (2012a) Accounting for intermediates: Production sharing and trade in value added. Journal of International Economics, 86(2), 224-236. https://doi.org/10.1016/j.jinteco.2011.10.003

Johnson, R. C., and Noguera, G. (2012b) Proximity and Production Fragmentation. American Economic Review, 102(3), 407-411. https://doi.org/10.1257/aer.102.3.407

Kano, L., and Oh, C. H. (2020) Global Value Chains in the Post-COVID World: Governance for Reliability. Journal of Management Studies, 1-5. https://doi.org/10.1111/joms.12626

Koopman, R., Wang, Z., and Wei, S.-J. (2014) Tracing Value-Added and Double Counting in Gross Exports. American Economic Review, 104(2), 459-494. https://doi.org/10.1257/aer.104.2.459

Lechler, M. (2019) Employment shocks and anti-EU sentiment. European Journal of Political Economy, 59, 266-295. 
Leontief, W. W. (1936) Quantitative Input and Output Relations in the Economic Systems of the United States. The Review of Economics and Statistics, 18(3), 105-125. https://doi.org/10.2307/1927837

Livesey, F. (2018) Unpacking the possibilities of deglobalisation. Cambridge Journal of Regions, Economy and Society, 11(1), 177-187. https://doi.org/10.1093/cjres/rsx030

Los, B., McCann, P., Springford, J., and Thissen, M. (2017) The mismatch between local voting and the local economic consequences of Brexit. Regional Studies, 51(5), 786-799. https://doi.org/10.1080/00343404.2017.1287350

Los, B., and Timmer, M. (2018) Measuring Bilateral Exports of Value Added: A Unified Framework. National Bureau of Economic Research, No. 24896. https://doi.org/10.3386/w24896

Los, B., Timmer, M. P., and de Vries, G. J. (2016) Tracing Value-Added and Double Counting in Gross Exports: Comment. American Economic Review, 106(7), 1958-1966. https://doi.org/10.1257/aer.20140883

Los, B., Timmer, M. P., and Vries, G. J. de. (2015) How Global Are Global Value Chains? A New Approach to Measure International Fragmentation. Journal of Regional Science, 55(1), 66-92. https://doi.org/10.1111/jors.12121

Mandel, A., and Veetil, V. (2020) The Economic Cost of COVID Lockdowns: An Out-ofEquilibrium Analysis. Economics of Disasters and Climate Change, 4(3), 431-451. https://doi.org/10.1007/s41885-020-00066-Z

Miller, R. E. (1966) Interregional Feedback Effects in Input-Output Models: Some Preliminary Results. Papers in Regional Science, 17(1), 105-125. https://doi.org/10.1111/j.14355597.1966.tb01344.x

Miller, R. E. and Blair, P. D. (2009) Input-Output Analysis: Foundations and Extensions. Cambridge, UK: Cambridge University Press, 2nd edition.

Miller, R. E., and Lahr, M. L. (2001) A Taxonomy of Extractions. In: Lahr, M.L. and Miller, R. E. (Eds.), Regional Science Perspectives in Economic Analysis: A Festschrift in Memory of Benjamin H. Stevens, Elsevier Science, Amsterdam, 407-441.

Miroudot, S. (2020) Reshaping the policy debate on the implications of COVID-19 for global supply chains. Journal of International Business Policy, 3, 430-442.

OECD (2020) Evaluating the initial impact of covid-19 containment measures on economic activity. OECD technical report, April 2020. 
Pichler, A., Pangallo, M., del Rio-Chanona, R. M., Lafond, F., and Farmer, J. D. (2020) Production networks and epidemic spreading: How to restart the UK economy? ArXiv:2005.10585 [Physics, q-Fin]. http://arxiv.org/abs/2005.10585

Reissl, S., Caiani, A., Lamperti F., Guerini, M., Vanni, F., Fagiolo, G., Ferraresi, T., Ghezzi, L., Napoletano, M., and Roventini, A. (2021) Assessing the Economic Effects of Lockdowns in Italy: A Dynamic Input-Output Approach. LEM Working Paper Series - 2021/3.

Sonis, M., Hewings, G. J. D., and Guo, J. (1996) Sources of Structural Change in Input-Output Systems: A Field of Influence Approach. Economic Systems Research, 8(1), 15-32. https://doi.org/10.1080/09535319600000002

Strange, R. (2020) The 2020 Covid-19 pandemic and global value chains. Journal of Industrial and Business Economics, 47, 455-465. https://doi.org/10.1007/s40812-020-00162-X

Sturgeon, T., Van Biesebroeck, J., and Gereffi, G. (2008) Value chains, networks and clusters: Reframing the global automotive industry. Journal of Economic Geography, 8(3), 297-321. https://doi.org/10.1093/jeg/lbn007

Thissen, M., Lankhuizen, M., van Oort, F., Los, B., and Diodato, D. (2018) EUREGIO: The Construction of a Global IO Database with Regional Detail for Europe for 2000-2010. SSRN Electronic Journal. https://doi.org/10.2139/ssrn.3285818

Thissen, M. van Oort, F., McCann, P., Ortega-Argilés, R., Husby, T. (2020) The Implications of Brexit for UK and EU Regional Competitiveness. Economic Geography, 96(5), 397-421, https://doi.org/10.1080/00130095.2020.1820862

Timmer, M. P., Erumban, A. A., Los, B., Stehrer, R., and de Vries, G. J. (2014) Slicing Up Global Value Chains. Journal of Economic Perspectives, 28(2), 99-118. https://doi.org/10.1257/jep.28.2.99

Timmer, M. P., Los, B., Stehrer, R., and de Vries, G. J. (2016) An Anatomy of the Global Trade Slowdown based on the WIOD 2016 Release. GGDC Research Memorandum GD-162, Groningen Growth and Development Centre, University of Groningen.

Timmer, M. P., Los, B., Stehrer, R., and de Vries, G. J. (2013) Fragmentation, incomes and jobs: An analysis of European competitiveness. Economic Policy, 28(76), 613-661. https://doi.org/10.1111/1468-0327.12018

Tocci, N. (2021) European Strategic Autonomy: What It Is, Why We Need It, How to Achieve It. Istituto Affari Internazionali. ISBN 978-88-9368-178-0.

van Bergeijk, P. A. G. (2018) On the brink of deglobalisation...again. Cambridge Journal of Regions, Economy and Society, 11(1), 59-72. https://doi.org/10.1093/cjres/rsx023 
van Bergeijk, P. A. G. (2019) Deglobalization 2.0 Trade and Openness During the Great Depression and the Great Recession. Edward Elgar, Cheltenham. ISBN: 9781788973458.

Wang, L., and Hewings, G. J. D. (2020) Will Increasing Tariffs on China Really Bring the Manufacturing Plants Back to the U.S.? Global Economic Review, 49(2), 127-149, https://doi.org/10.1080/1226508X.2020.1744464 


\section{Online Appendix A}

\section{A.1. The C-country, R-region, $\mathbf{N}$-sector input-output model}

This section introduces a global input-output model with $C$ countries, $R$ regions, and $N$ sectors. Suppose the world economy consists of $C$ countries which in turn consist of a (variable) number of regions $R$, and each of which is comprised of $N$ industries. Sectors in all regions and countries exchange intermediate goods and services with each other and deliver final products to consumers in all regions in all countries. The structure of such a global economy can be captured by a global input-output table as presented in a stylized way in Figure A.1.

The rows of the table give the total dollar value of deliveries of output from a particular industry in each region in a given country to another industry for intermediate use (block matrices labelled $\mathbf{Z}$ ), or to final users (block matrices labelled $\mathbf{F}$ ), either within the same region, to another region in the same country, to another region in other EU countries or to extra-EU countries. ${ }^{1}$

The $\mathbf{Z}$ block matrices are the core of an input-output table. In the stylized Figure A.2.1, the $\mathbf{Z}$ blocks on the main diagonal (shaded) include input-output connections within the economies grouped in the block. For example, the $\mathbf{Z}^{\text {rr }}$ block is an $N \times N$ matrix consisting of intra-region deliveries, i.e., it includes sectoral input-output flows that take place in the same focal region.

\begin{tabular}{|c|c|c|c|c|c|c|c|c|c|}
\hline & $\begin{array}{l}\text { Focal Region } \\
\text { in EU }\end{array}$ & $\begin{array}{l}\text { Other regions } \\
\text { in country of } \\
\text { focal region }\end{array}$ & $\begin{array}{c}\text { Regions in } \\
\text { other EU } \\
\text { countries }\end{array}$ & $\begin{array}{c}\begin{array}{c}\text { Countries } \\
\text { outside the } \\
\text { EU }\end{array} \\
\end{array}$ & $\begin{array}{l}\text { Focal Region } \\
\text { in EU }\end{array}$ & $\begin{array}{l}\text { Other regions } \\
\text { in country of } \\
\text { focal region }\end{array}$ & $\begin{array}{l}\text { Regions in } \\
\text { other EU } \\
\text { countries }\end{array}$ & $\begin{array}{c}\text { Countries } \\
\text { outside the } \\
\text { EU }\end{array}$ & $\begin{array}{c}\text { Gross } \\
\text { output }\end{array}$ \\
\hline $\begin{array}{l}\text { Focal Region } \\
\text { in EU }\end{array}$ & $\mathbf{Z}^{\mathrm{rr}}$ & $\mathbf{Z}^{\mathrm{rc}}$ & $\mathbf{Z}^{\mathrm{re}}$ & $\mathbf{Z}^{\text {ro }}$ & $\mathrm{f}^{\mathrm{rr}}$ & $\mathbf{F}^{\mathrm{rc}}$ & $\mathbf{F}^{\mathrm{re}}$ & $\mathbf{F}^{\mathrm{ro}}$ & $\mathbf{x}^{\mathrm{r}}$ \\
\hline $\begin{array}{l}\text { Other regions } \\
\text { in country of } \\
\text { focal region }\end{array}$ & $\mathbf{Z}^{\text {cr }}$ & $\mathbf{Z}^{\mathrm{cc}}$ & $\mathbf{Z}^{\text {ce }}$ & $\mathbf{Z}^{\text {co }}$ & $\mathbf{f}^{\mathrm{r} r}$ & $\mathbf{F}^{\mathrm{cc}}$ & $\mathbf{F}^{\mathrm{ce}}$ & $\mathbf{F}^{\mathrm{co}}$ & $\mathbf{x}^{\mathrm{c}}$ \\
\hline $\begin{array}{c}\text { Regions in } \\
\text { other EU } \\
\text { countries } \\
\end{array}$ & $\mathbf{Z}^{\mathrm{er}}$ & $\mathbf{Z}^{\mathrm{ec}}$ & $\mathbf{Z}^{\text {ee }}$ & $\mathbf{Z}^{\mathrm{eo}}$ & $\mathrm{f}^{\mathrm{er}}$ & $\mathbf{F}^{\mathrm{ec}}$ & $F^{\mathrm{ee}}$ & $\mathbf{F}^{\mathrm{eo}}$ & $\mathbf{x}^{\mathrm{e}}$ \\
\hline $\begin{array}{c}\begin{array}{c}\text { Countries } \\
\text { outside the } \\
\text { EU }\end{array} \\
\end{array}$ & $\mathbf{Z}^{\text {or }}$ & $\mathbf{Z}^{\mathrm{oc}}$ & $\mathbf{Z}^{\mathrm{oe}}$ & $\mathbf{Z}^{\mathrm{oo}}$ & for & $\mathbf{F}^{\mathrm{oc}}$ & $\mathbf{F}^{\mathrm{oe}}$ & $\mathbf{F}^{\mathrm{oo}}$ & $\mathbf{x}^{\mathrm{O}}$ \\
\hline Value added & $\mathbf{v}^{r^{\prime}}$ & $\mathbf{v}^{c^{\prime}}$ & $\mathbf{v}^{\mathrm{e}^{\prime}}$ & $\mathbf{v}^{0^{\prime}}$ & & & & & \\
\hline Gross output & $\mathbf{x}^{\mathrm{r}^{\prime}}$ & $\mathbf{x}^{\mathrm{c}^{\prime}}$ & $\mathbf{x}^{\mathrm{e}^{\prime}}$ & $\mathbf{x}^{\mathrm{o}^{\prime}}$ & & & & & \\
\hline
\end{tabular}

Figure A.1. A global input-output table with regional details

\footnotetext{
${ }^{1}$ Matrices are indicated by bold capitals, vectors by bold lowercases and scalars by italic lowercases. Diagonal matrices are indicated by a hat over the vector containing the elements on the main diagonal. Primes indicate transposition.
} 
$\mathbf{Z}^{\text {cc }}$ has $N(R c-1)$ rows and $N(R c-1)$ columns. This matrix block includes input-output connections between industries in other regions of the country of which $r$ is a part, to industries in other regions than $r$ in the same country. If, for example, $r$ refers to Piemonte, $\mathbf{Z}^{\text {cc }}$ contains deliveries of industries in Lombardia to industries in Lombardia itself, but also to industries in Toscana. Since in our scenario analysis we distinguish between the consequences of a deglobalisation from intra and extra-EU value chains, we split the set of countries to which the focal region $r$ does not belong to (regions in) other EU countries, and extra-EU countries. In $\mathbf{Z}^{\mathbf{e e}}$ are included all the transactions between industries in regions of EU countries to which $r$ does not belong. Continuing our example for Piemonte, this matrix provides quantitative information about the values of intermediate input flows between Groningen (a region in a different EU country) and Stuttgart (also a region in an EU country other than Italy), among many other flows. Finally, $\mathbf{Z}^{\mathbf{o o}}$ contains the values of all transactions between industries in countries that do not belong to the EU.

The off-diagonal blocks within $\mathbf{Z}$ refer to bilateral trade in intermediate inputs between industries in different types of geographical entities. These block matrices can contain input sales by industries in the focal region $r$ to industries placed in other regions of the same country $\left(\mathbf{Z}^{\mathbf{r c}}\right)$, as well as they might indicate the value of intermediate input sales by industries in the focal region $r$ to industries placed in other EU regions $\left(\mathbf{Z}^{\mathbf{r e}}\right)$, or they might contain flows in the opposite direction, for example intermediate inputs imports of the focal region $r$ from extra-EU countries $\left(\mathbf{Z}^{\text {or }}\right)$.

The matrices and vectors in the block labelled $\mathbf{F}$ have a similar interpretation in terms of the regions and countries involved but refer to deliveries of final products. Specifically, the $\mathbf{F}$ block matrices contain data of final demand for the output of each producing industry that is demand of nonindustry consumers such as households and government. Final demand is the demand for goods, which are not used to produce other goods (as opposed to intermediate demand). In our analysis, we do not distinguish between final uses, as a consequence of which consumption demand by households, government consumption, gross fixed capital formation and changes in inventories for the output of industries in regions and countries have been aggregated into single numbers. This explain why final demand as exerted in region $r$ is represented by column vectors $\mathbf{f}^{\mathbf{r}}$, rather than by matrices with multiple columns.

The fundamental accounting identity of any input-output table is that total use of output in a row equals total output of the same industry as indicated by the sum of inputs in the respective column in the left-hand part of the table. The columns indicate the amounts of intermediate inputs needed for production; hence, they are informative about the technology of production. What remains between total output and total intermediate inputs is value added (v), that is the direct contribution of the factors of production to output. 
Let $\mathbf{Z}$ be the transaction matrix, $\mathbf{F}$ be the matrix of industry final demands, and $\mathbf{x}$ the vector of industry gross output. The accounting equations are given as $\mathbf{x}=\mathbf{Z i}+\mathbf{F i}$, where $\mathbf{i}$ is the summation vector, i.e. a vector of all ones. Define the direct input coefficients as the ratio of input supplied by $i$ and bought by $j$ over the gross output of sector $j$ as $a_{i j}=z_{i j} / x_{j}$, which is the typical element of the economy's direct requirements matrix A, also known as the technical coefficients matrix. We know $\mathbf{A}=\mathbf{Z} \hat{\mathbf{x}}^{-\mathbf{1}}$, where the circumflex or hat denotes a diagonal matrix, in this case values on the diagonal are elements of the vector $\mathbf{x}$. Thus, we can substitute $\mathbf{A x}=\mathbf{Z i}$ in the accounting equations to get $\mathbf{x}=\mathbf{A x}+\mathbf{F i}$. Solving for $\mathbf{x}$ yields:

$$
\mathbf{x}=(\mathbf{I}-\mathbf{A})^{-1} \mathbf{F i}=\mathbf{L F i}
$$

where $\mathbf{I}$ is the identity matrix and $\mathbf{L} \equiv(\mathbf{I}-\mathbf{A})^{\mathbf{- 1}}$ is the Leontief inverse or multiplier matrix, which makes clear the direct and indirect dependence of each of gross outputs on the values of each of the final demand. In order to relate equation (1) to the value-added of each region/country, we premultiply equation (1) by the value-added coefficients diagonal matrix $\widehat{\mathbf{V}}$, i.e. in which an arbitrary element on the main diagonal is $v_{j}^{s}=v_{j}^{S} / x_{j}^{s}$. Here, $v_{j}^{S}$ denotes the value added, subscript $j$ denotes the industry and superscript $s$ identifies the region/country. This leads to the vector:

$$
\mathbf{v}=\widehat{\mathbf{V}}(\mathbf{I}-\mathbf{A})^{-\mathbf{1}} \mathbf{F i}=\mathbf{L F i}
$$

We start from this equation to compute the impact of our three deglobalisation scenarios.

\section{A.2. First scenario: The end of intermediate flows}

In this scenario we are interested in the extent to which value-added of EU regions is exposed to deglobalisation. Specifically, we ask what would happen if industries in EU regions stop importing and exporting intermediate inputs. To answer this question, we employ a modified version of the standard hypothetical extraction method.

Typically, this technique is used to estimate the importance of a sector $i$. The procedure consists of deleting the $i$-th row and column of the input-output matrix $\mathbf{A}$, and then using the Leontief model, to compute the reduced outputs obtained when $i=0$ and compare with total output before extraction (see Miller and Lahr, 2001, and Dietzenbacher and Lahr, 2013, for insights and extensions). Therefore, extracting industry $i$ requires that the $i$-th row and column of the $\mathbf{A}$ matrix 
are set equal to zero. We define this matrix by $\mathbf{A}^{*}$. Thus, the estimated new vector of sector valueadded will be:

$$
\mathbf{v}=\widehat{\mathbf{V}}\left(\mathbf{I}-\mathbf{A}^{*}\right)^{-\mathbf{1}} \mathbf{F i}=\mathbf{L F i}
$$

However, Chen et al. (2018) show that this general case can be easily extended to a multiregion input-output framework with $C$ countries $R$ regions and $N$ production sectors to quantify the effect of global value chains (GVCs) interruption on value-added, as induced by hypothetically extracting trade flows between regions/countries. In our first scenario we build on Chen et al. (2018) and simulate the impact of deglobalisation by zeroing the imports and exports of intermediate inputs.

We employ the EUREGIO database that includes data for 14 industries in 246 NUTS 2 regions of the EU-25, plus data at the country-level for the same 14 industries in Bulgaria, Romania and other 14 extra-EU trading partners, for a total of 41 countries. Using partitioned matrices, the coefficient matrix $\mathbf{A}$ can be presented in summary as:

$$
\mathbf{A}=\left[\begin{array}{cccccc}
\mathbf{A}^{\mathrm{E}_{1}^{1} \mathrm{E}_{1}^{1}} & \mathbf{A}^{\mathrm{E}_{1}^{1} \mathrm{E}_{1}^{2}} & \cdots & \mathbf{A}_{1}^{\mathrm{E}_{1}^{1} \mathrm{E}_{25}^{246}} & \mathbf{A}_{1}^{\mathrm{E}_{1}^{1} \mathrm{R}} & \mathbf{A}^{\mathrm{E}_{1}^{1} \mathrm{O}} \\
\mathbf{A}^{\mathrm{E}_{1}^{2} \mathrm{E}_{1}^{1}} & \mathbf{A}_{1}^{\mathrm{E}_{1}^{2} \mathrm{E}_{1}^{2}} & \cdots & \mathbf{A}_{1}^{\mathrm{E}_{1}^{2} \mathrm{E}_{25}^{246}} & \mathbf{A}^{\mathrm{E}_{1}^{2} \mathrm{R}} & \mathbf{A}^{\mathrm{E}_{1}^{2} \mathrm{O}} \\
\vdots & \vdots & \ddots & \vdots & \vdots & \vdots \\
\mathbf{A}^{\mathrm{E}_{25}^{246} \mathrm{E}_{1}^{1}} & \mathbf{A}_{25}^{\mathrm{E}_{25}^{246} \mathrm{E}_{1}^{2}} & \cdots & \mathbf{A}_{25}^{\mathrm{E}_{25}^{246} \mathrm{E}_{25}^{246}} & \mathbf{A}^{\mathrm{E}_{25}^{246} \mathrm{R}} & \mathbf{A}^{\mathrm{E}_{25}^{246} \mathrm{O}} \\
\mathbf{A}^{\mathrm{RE}} & \mathbf{A}^{\mathrm{RE}_{1}^{2}} & \cdots & \mathbf{A}^{\mathrm{RE}_{25}^{24}} & \mathbf{A}^{\mathrm{RR}} & \mathbf{A}^{\mathrm{RO}} \\
\mathbf{A}^{\mathrm{OE}} & \mathbf{A}^{\mathrm{OE}_{1}^{2}} & \cdots & \mathbf{A}^{\mathrm{OE}_{25}^{246}} & \mathbf{A}^{\mathrm{OR}} & \mathbf{A}^{\mathrm{OO}}
\end{array}\right]
$$

where E stands for EU-25 countries, R for rest of EU (Bulgaria and Romania), and O for extra-EU. The blocks are divided by regions (superscripts) and countries (subscripts).

Extracting intermediate trade flows from and to EU regions requires that the matrices relative to imports and exports of inputs are replaced by matrices of appropriate dimension filled with zeros, such that the new matrix $\mathbf{A}^{*^{\prime}}$ consists of domestic matrix blocs and zero elsewhere:

$$
\mathbf{A}^{*^{\prime}}=\left[\begin{array}{cccccc}
\mathbf{A}^{\mathrm{E}_{1}^{1} \mathrm{E}_{1}^{1}} & \mathbf{A}^{\mathrm{E}_{1}^{1} \mathrm{E}_{1}^{2}} & \cdots & 0 & 0 & 0 \\
\mathbf{A}_{1}^{\mathrm{E}_{1}^{2} \mathrm{E}_{1}^{1}} & \mathbf{A}_{1}^{\mathrm{E}_{1}^{2} \mathrm{E}_{1}^{2}} & \cdots & 0 & 0 & 0 \\
\vdots & \vdots & \ddots & \vdots & \vdots & \vdots \\
0 & 0 & \cdots & \mathbf{A}^{\mathrm{E}_{25}^{246} \mathrm{E}_{25}^{246}} & 0 & 0 \\
0 & 0 & \cdots & 0 & \mathbf{A}^{\mathrm{RR}} & 0 \\
0 & 0 & \cdots & 0 & 0 & \mathbf{A}^{\mathrm{OO}}
\end{array}\right]
$$


To study the impact of a complete deglobalisation of value chains, we use this matrix in equation (A.3) and estimate the new vector of sector value-added. As explained in Giammetti et al. (2020) the relative change before and after extraction $\left(\mathbf{v}^{*}-\mathbf{v}\right) / \mathbf{v}$ can be considered as a measure of the exposure of a sector, a region or a country to shocks involving GVCs. Here we use this measure to study the extent to which EU regions are exposed to a complete deglobalisation of value-chains.

We extend the general case of a complete interruption of GVCs to study the impact of a partial interruption. Specifically, we hypothesize two intermediate cases: (i) the case in which the interruption of intermediate flows involves only foreign countries, thus leaving the deliveries of inputs between EU regions unchanged; and (ii) the case in which the interruption of intermediate value chains involves only the deliveries between EU regions, leaving the input relationships with extra-EU countries unchanged.

In the first case (i), the matrix blocks of $\mathbf{A}$ relating to import and export of inputs between EU regions and extra-EU countries are zeroed:

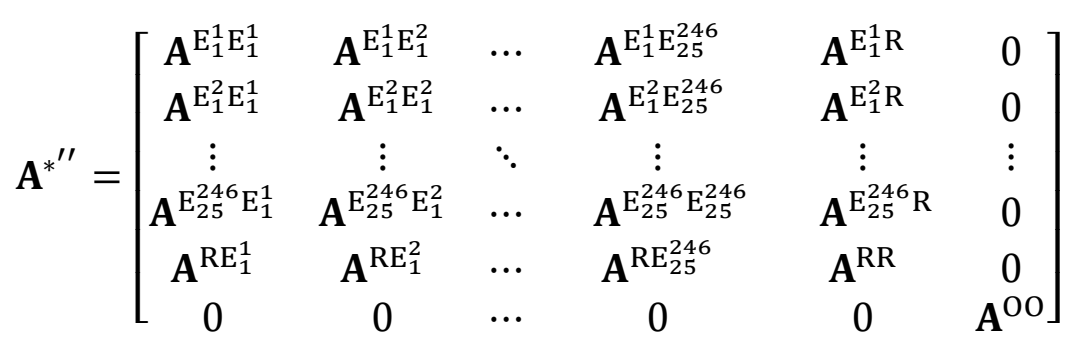

In case (ii), are zeroed the matrix blocks of $\mathbf{A}$ relating the deliveries of inputs across EU regions.

$$
\mathbf{A}^{*^{\prime \prime \prime}}=\left[\begin{array}{cccccc}
\mathbf{A}^{\mathrm{E}_{1}^{1} \mathrm{E}_{1}^{1}} & \mathbf{A}^{\mathrm{E}_{1}^{1} \mathrm{E}_{1}^{2}} & \cdots & 0 & 0 & \mathbf{A}^{\mathrm{E}_{1}^{1} \mathrm{O}} \\
\mathbf{A}^{\mathrm{E}_{1}^{2} \mathrm{E}_{1}^{1}} & \mathbf{A}^{\mathrm{E}_{1}^{2} \mathrm{E}_{1}^{2}} & \cdots & 0 & 0 & \mathbf{A}^{\mathrm{E}_{1}^{2} \mathrm{O}} \\
\vdots & \vdots & \ddots & \vdots & \vdots & \vdots \\
0 & 0 & \cdots & \mathbf{A}_{25}^{\mathrm{E}_{25}^{26} \mathrm{E}_{25}^{246}} & 0 & \mathbf{A}_{25}^{\mathrm{E}_{25}^{240}} \\
0 & 0 & \cdots & 0 & \mathbf{A}^{\mathrm{RR}} & \mathbf{A}^{\mathrm{RO}} \\
\mathbf{A}^{\mathrm{OE}_{1}^{1}} & \mathbf{A}^{\mathrm{OE}_{1}^{2}} & \cdots & \mathbf{A}^{\mathrm{OE}_{25}^{246}} & \mathbf{A}^{\mathrm{OR}} & \mathbf{A}^{\mathrm{OO}}
\end{array}\right]
$$

Again, we us $\mathbf{A}^{*^{\prime \prime}}$ and $\mathbf{A}^{*^{\prime \prime \prime}}$ in equation (A.3) to compute the new value-added and then the relative change with the pre-shock value-added. 


\section{A.3. Second scenario: A return to the past production schemes and trade patterns}

In the second scenario we study the economic implication of a return to a less integrated world economy. Specifically, we evaluate how the value-added in 2010 of EU regions would change if production took place with the production schemes and trade patterns of 2000 . To do so we build on the literature on structural change in input-output systems (Sonis et al., 1996) and on the method applied in the first scenario.

The input requirements matrix $\mathbf{A}$ gives a quantitative description of the world production structure. However, this is not only determined by technological input requirements, but also by interregional and international trade patterns. Therefore, a simple way to verify how the valueadded would change if the production schemes went back in time is to calculate the value-added at time $t$ using the matrix of the technical coefficients at time $t-n$. Here, we leave at the 2010 the value-added coefficient matrix $(\widehat{\mathbf{V}})$ and the final demand matrix $(\mathbf{F})$, while we fix at the 2000 the technical coefficient matrix $\mathbf{A}^{\#}$ :

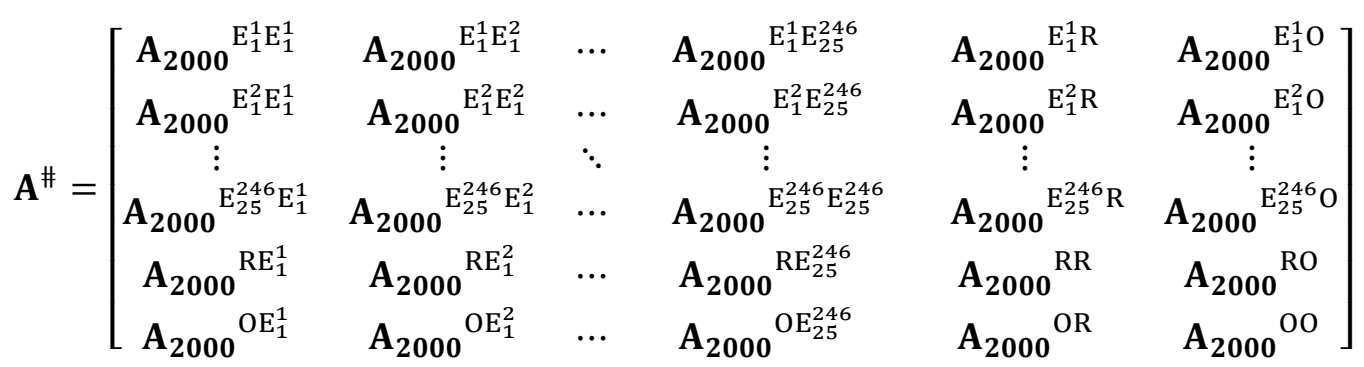

Then we use equation (A.3) to compute the value-added generated with the technical coefficient matrix $\mathbf{A}^{\#}$.

\section{A.2.4. Third scenario: The Europeanisation of global value chains}

Dietzenbacher et al. (2019) have recently developed a global multicountry version of the hypothetical extraction method, the so-called global extraction method (GEM). Giammetti (2020) employ an extended version of this method to simulate trade diversion in a post-Brexit world. In the third scenario we build on these contributions to simulate the impact of a GVCs Europeanisation (i.e. a regionalisation of GVCs) on EU regional economies and extra-EU countries. Specifically, we study the impact of a hypothetic future world in which the EU regions totally replace the 
intermediate inputs imported from extra-EU countries with the same intermediate inputs from other EU countries.

When performing the hypothetical extraction method, it is important that other things remain unchanged in order to single out the impact of the extraction. It is therefore assumed that, at the national level, the remaining industries still receive the inputs they need, i.e. the inputs requirements delivered by the extracted industry are met by additional imports in the post-extraction situation. For this reason, according to Dietzenbacher et al. (2019) performing the hypothetical extraction method at the global level is problematic, as the assumption to import the required inputs from outside 'the system' is no longer possible. To overcome this drawback, the GEM suggests allocating the missing flows proportionally over the columns of the global input-output matrix.

We adopt this strategy by zeroing the intermediary imports from extra-EU countries and reallocating them proportionally over the intra-EU intermediary input flows of the respective EU regions, not allowing for domestic import substitution. This method requires that the matrices relative to imports of inputs sourced in extra-EU countries are replaced by matrices of appropriate dimension filled with zeros and that the flows of intermediate imports sourced in intra-EU countries are proportionally expanded, as follows:

$$
\mathbf{A}^{\dagger}=\left[\begin{array}{cccccc}
\mathbf{A}^{\mathrm{E}_{1}^{1} \mathrm{E}_{1}^{1}} & \mathbf{A}^{\mathrm{E}_{1}^{1} \mathrm{E}_{1}^{2+}} & \cdots & \mathbf{A}^{\mathrm{E}_{1}^{1} \mathrm{E}_{25}^{246+}} & \mathbf{A}^{\mathrm{E}_{1}^{1} \mathrm{R}^{+}} & \mathbf{A}^{\mathrm{E}_{1}^{1} \mathrm{O}} \\
\mathbf{A}^{\mathrm{E}_{1}^{2} \mathrm{E}_{1}^{1+}} & \mathbf{A}^{\mathrm{E}_{1}^{2} \mathrm{E}_{1}^{2}} & \cdots & \mathbf{A}^{\mathrm{E}_{1}^{2} \mathrm{E}_{25}^{246+}} & \mathbf{A}^{\mathrm{E}_{1}^{2} \mathrm{R}^{+}} & \mathbf{A}^{\mathrm{E}_{1}^{2} \mathrm{O}} \\
\vdots & \vdots & \ddots & \vdots & \vdots & \vdots \\
\mathbf{A}^{\mathrm{E}_{25}^{246} \mathrm{E}_{1}^{1+}} & \mathbf{A}_{25}^{\mathrm{E}_{25}^{26} \mathrm{E}_{1}^{2+}} & \cdots & \mathbf{A}^{\mathrm{E}_{25}^{246} \mathrm{E}_{25}^{246}} & \mathbf{A}_{25}^{\mathrm{E}_{25}^{46} \mathrm{R}^{+}} & \mathbf{A}^{\mathrm{E}_{25}^{246} \mathrm{O}} \\
\mathbf{A}^{\mathrm{RE} \mathrm{E}_{1}^{1+}} & \mathbf{A}^{\mathrm{RE}} & \cdots & \mathbf{A}_{15}^{\mathrm{RE}_{25}^{24+}} & \mathbf{A}^{\mathrm{RR}} & \mathbf{A}^{\mathrm{RO}} \\
0 & 0 & \cdots & 0 & 0 & \mathbf{A}^{\mathrm{OO}}
\end{array}\right]
$$

As in the GEM, we assume that the matrix of technology coefficients remains fixed, i.e. column sums of the pre- and post-generalized extraction are equivalent. We use this new coefficient matrix to calculate the new value-added as defined by equation (A.3).

\section{A.5. Measuring the fragmentation of production with input-output tools}

In Section 3 we present a description of the trends in international fragmentation of the EU regional production network over the period 2000-2010. Specifically, we define the value chain of final goods and services produced in the EU production network as the set of all value-adding activities that are needed in their production. Then, we compute the international fragmentation as the share of foreign value-added in the value of final products. Finally, we study the geography of this 
fragmentation by splitting the foreign value-added into value-added within EU regions and valueadded outside the EU.

We use the methodology presented in Los et al. (2015) in a multiregional setting. To decompose the value of a final product into value added contribution in any region and country in the world we start with equation (A.3).

This calculation allows us to decompose value chains of final products that are identified by the last stage of production: a particular industry $i$ located in a specific region/country $j$, denoted by $(i, j)$.

Define the final output value of a product $(i, j)$ by $\operatorname{FINO}(i, j)$ and the value-added by region/country $k$ in its production by $\operatorname{VA}(k)(i, j)$. The vector $\mathrm{v}$ includes the matching $\operatorname{VA}(k)(i, j)$ levels for each $(i, j)$ such that:

$$
\operatorname{FINO}(i, j)=\sum_{\boldsymbol{k}} \operatorname{VA}(k)(i, j)
$$

If we sum the contributions over all regions/countries, we obtain the final output value of $(i, j)$.

Los et al. (2015) define their measure of foreign value added (FVA) as all value-added outside the country of completion $j$ :

$$
\operatorname{FVA}(i, j)=\sum_{\boldsymbol{k} \neq \mathrm{j}} \operatorname{VA}(k)(i, j)=\operatorname{FINO}(i, j)-\operatorname{VA}(j)(i, j)
$$

Then, to measure the relevance of foreign value-added in the generation of the value-added of $(i, j)$, we can express it as a share of all value-added in the production of $(i, j)$ :

$$
\operatorname{FVAS}(i, j)=\operatorname{FVA}(i, j) / \operatorname{FINO}(i, j)
$$

This share corresponds to the measure we employed to describe the global fragmentation of production of EU regions.

In the second part of Section 3 we decompose $\operatorname{FVAS}(i, j)$ into the value-added share of EU regions/countries and the remaining value-added share that is added outside the EU. This further decomposition can be easily computed by splitting FVA as defined in equation (A.11) into EUFVA and extra-EU-FVA. EU-FVA in the value of product $\mathrm{i}$ with region/country $\mathrm{j}$ as country of completion is defined as the value-added contribution of the EU minus the contribution of the country itself: 


$$
\begin{gathered}
\operatorname{EU}-\operatorname{FVA}(i, j)=\sum_{\boldsymbol{k} \in \text { region of } \boldsymbol{j}} \operatorname{VA}(k)(i, j)-\operatorname{VA}(j)(i, j), \\
\operatorname{EU}-\operatorname{FVAS}(i, j)=\operatorname{EU}-\operatorname{FVA}(i, j) / \operatorname{FinO}(i, j) .
\end{gathered}
$$

The share of EU-FVA in the value chain of $(i, j)$ indicates to what extent the production of $(i, j)$ is fragmented within EU value chains.

Along the same lines, we measure extra-EU fragmentation as the value-added contribution of all countries outside the EU, as follows:

$$
\operatorname{Extra}-\operatorname{EU}-\operatorname{FVA}(i, j)=\sum_{\boldsymbol{k} \in \text { outside region of } \boldsymbol{j}} \operatorname{VA}(k)(i, j)
$$

and

$$
\text { Extra-EU-FVAS }(i, j)=\text { Extra-EU-FVA }(i, j) / \operatorname{FINO}(i, j)
$$

\section{References}

Dietzenbacher, E., and Lahr, M. L. (2013) Expanding Extractions. Economic Systems Research, 25(3), 341-360. https://doi.org/10.1080/09535314.2013.774266

Dietzenbacher, E., van Burken, B., and Kondo, Y. (2019) Hypothetical extractions from a global perspective. Economic Systems Research, 31(4), 505-519. https://doi.org/10.1080/09535314.2018.1564135

Giammetti, R. (2020). Tariffs, domestic import substitution and trade diversion in input-output production networks: An exercise on Brexit. Economic Systems Research, 32(3), 318-350. https://doi.org/10.1080/09535314.2020.1738347

Los, B., Timmer, M. P., and Vries, G. J. de. (2015) How Global Are Global Value Chains? A New Approach to Measure International Fragmentation. Journal of Regional Science, 55(1), 66-92. https://doi.org/10.1111/jors.12121

Miller, R. E., and Lahr, M. L. (2001) A Taxonomy of Extractions. In: Lahr, M.L. and Miller, R. E. (Eds.), Regional Science Perspectives in Economic Analysis: A Festschrift in Memory of Benjamin H. Stevens, Elsevier Science, Amsterdam, 407-441. 


\section{Online Appendix B}

Table B.1. Output losses due to a total interruption of GVCs (Figure 3)

\begin{tabular}{|c|c|c|}
\hline$\overline{\mathrm{CODE}}$ & COUNTRY_REGION & $\begin{array}{c}\text { Output Losses } \\
\text { (percentage) }\end{array}$ \\
\hline$\overline{\mathrm{AT} 11}$ & AUSTRIA_Burgenland & 20.01 \\
\hline AT12 & AUSTRIA_Niederosterreich & 21.12 \\
\hline AT13 & AUSTRIA_Wien & 20.83 \\
\hline AT21 & AUSTRIA_Karnten & 21.46 \\
\hline AT22 & AUSTRIA_Steiermark & 21.17 \\
\hline AT31 & AUSTRIA_Oberosterreich & 21.97 \\
\hline AT32 & AUSTRIA_Salzburg & 21.38 \\
\hline AT33 & AUSTRIA_Tirol & 22.01 \\
\hline AT34 & AUSTRIA_Vorarlberg & 23.21 \\
\hline BE10 & BELGIUM_Region de Bruxelles & 24.88 \\
\hline BE21 & BELGIUM_Prov. Antwerpen & 29.03 \\
\hline BE22 & BELGIUM_Prov. Limburg (B) & 28.64 \\
\hline BE23 & BELGIUM_Prov. Oost-Vlaanderen & 25.14 \\
\hline BE24 & BELGIUM_Prov. Vlaams Brabant & 27.36 \\
\hline BE25 & BELGIUM_Prov. West-Vlaanderen & 27.91 \\
\hline BE31 & BELGIUM_Prov. Brabant Wallon & 29.58 \\
\hline BE32 & BELGIUM_Prov. Hainaut & 24.45 \\
\hline BE33 & BELGIUM_Prov. Liege & 27.01 \\
\hline BE34 & BELGIUM_Prov. Luxembourg (B) & 26.92 \\
\hline BE35 & BELGIUM_Prov. Namur & 25.40 \\
\hline $\mathrm{CZ} 01$ & CZECH REPUBLIC_Praha & 24.21 \\
\hline $\mathrm{CZ02}$ & CZECH REPUBLIC_Stredni Cechy & 26.28 \\
\hline $\mathrm{CZ} 03$ & CZECH REPUBLIC_Jihozapad & 25.47 \\
\hline $\mathrm{CZ04}$ & CZECH REPUBLIC_Severozapad & 24.49 \\
\hline CZ05 & CZECH REPUBLIC_Severovychod & 25.86 \\
\hline CZ06 & CZECH REPUBLIC_Jihovychod & 25.53 \\
\hline $\mathrm{CZ07}$ & CZECH REPUBLIC_Stredni Morava & 25.30 \\
\hline CZ08 & CZECH REPUBLIC_Moravskoslezko & 26.00 \\
\hline DE11 & GERMANY_Stuttgart & 19.88 \\
\hline DE12 & GERMANY_Karlsruhe & 18.91 \\
\hline DE13 & GERMANY_Freiburg & 18.09 \\
\hline DE14 & GERMANY_Tubingen & 18.83 \\
\hline DE21 & GERMANY_Oberbayern & 19.49 \\
\hline DE22 & GERMANY_Niederbayern & 18.05 \\
\hline DE23 & GERMANY_Oberpfalz & 18.55 \\
\hline DE24 & GERMANY_Oberfranken & 17.55 \\
\hline DE25 & GERMANY_Mittelfranken & 18.13 \\
\hline DE26 & GERMANY_Unterfranken & 18.20 \\
\hline DE27 & GERMANY_Schwaben & 17.89 \\
\hline DE30 & GERMANY_Berlin & 17.67 \\
\hline DE40 & GERMANY_Brandenburg - Nordost & 16.95 \\
\hline DE50 & GERMANY_Bremen & 18.44 \\
\hline
\end{tabular}




\begin{tabular}{|c|c|c|}
\hline DE60 & GERMANY_Hamburg & 16.22 \\
\hline DE71 & GERMANY_Darmstadt & 19.39 \\
\hline DE72 & GERMANY_Giessen & 17.49 \\
\hline DE73 & GERMANY_Kassel & 17.44 \\
\hline DE80 & GERMANY_Mecklenburg-Vorpommern & 15.89 \\
\hline DE91 & GERMANY_Braunschweig & 18.70 \\
\hline DE92 & GERMANY_Hannover & 17.56 \\
\hline DE93 & GERMANY_Luneburg & 14.72 \\
\hline DE94 & GERMANY_Weser-Ems & 17.29 \\
\hline DEA1 & GERMANY_Dusseldorf & 15.53 \\
\hline DEA2 & GERMANY_Koln & 16.01 \\
\hline DEA3 & GERMANY_Munster & 15.55 \\
\hline DEA4 & GERMANY_Detmold & 17.88 \\
\hline DEA5 & GERMANY_Arnsberg & 16.08 \\
\hline DEB1 & GERMANY_Koblenz & 16.76 \\
\hline DEB2 & GERMANY_Trier & 15.42 \\
\hline DEB3 & GERMANY_Rheinhessen-Pfalz & 15.96 \\
\hline DEC0 & GERMANY_Saarland & 18.35 \\
\hline DED2 & GERMANY_Chemnitz & 16.33 \\
\hline DED4 & GERMANY_Dresden & 18.17 \\
\hline DED5 & GERMANY_Leipzig & 16.30 \\
\hline DEE0 & GERMANY_Sachsen-Anhalt & 15.64 \\
\hline DEF0 & GERMANY_Schleswig-Holstein & 15.47 \\
\hline DEG0 & GERMANY_Thüringen & 17.18 \\
\hline DK01 & DENMARK_Hovedstadsreg & 19.27 \\
\hline DK02 & DENMARK_Ost for Storebælt & 19.01 \\
\hline DK03 & DENMARK_West_for_Storebelt & 19.60 \\
\hline EE00 & ESTONIA_Eesti & 24.95 \\
\hline ES11 & SPAIN_Galicia & 8.74 \\
\hline ES12 & SPAIN_Principado de Asturias & 9.08 \\
\hline ES13 & SPAIN_Cantabria & 10.25 \\
\hline ES21 & SPAIN_Pais Vasco & 11.46 \\
\hline ES22 & SPAIN_Foral de Navarra & 10.65 \\
\hline ES23 & SPAIN_La Rioja & 10.62 \\
\hline ES24 & SPAIN_Aragon & 10.06 \\
\hline ES30 & SPAIN_Comunidad de Madrid & 12.12 \\
\hline ES41 & SPAIN_Castilla y Leon & 8.28 \\
\hline ES42 & SPAIN_Castilla-la Mancha & 9.28 \\
\hline ES43 & SPAIN_Extremadura & 9.81 \\
\hline ES51 & SPAIN_Cataluna & 11.19 \\
\hline ES52 & SPAIN_Comunidad Valenciana & 9.89 \\
\hline ES53 & SPAIN_Illes Balears & 8.32 \\
\hline ES61 & SPAIN_Andalucia & 6.46 \\
\hline ES62 & SPAIN_Region de Murcia & 10.50 \\
\hline ES63 & SPAIN_Ceuta (ES) & 9.25 \\
\hline ES64 & SPAIN_Melilla (ES) & 9.72 \\
\hline ES70 & SPAIN_Canarias_ES & 7.68 \\
\hline FI19 & FINALND_Ita-Suomi & 22.00 \\
\hline FI1B & FINALND_Etela-Suomi & 19.25 \\
\hline FI1C & FINALND_Lansi-Suomi & 21.12 \\
\hline
\end{tabular}




\begin{tabular}{|c|c|c|}
\hline FI1D & FINALND_Pohjois-Suomi & 23.57 \\
\hline FI20 & FINALND_Aland & 19.33 \\
\hline FR10 & FRANCE_Ile de France & 9.17 \\
\hline FRF2 & FRANCE_Champagne-Ardenne & 11.33 \\
\hline FRE2 & FRANCE_Picardie & 9.26 \\
\hline FRD2 & FRANCE_Haute-Normandie & 11.48 \\
\hline FRB0 & FRANCE_Centre & 9.60 \\
\hline FRD1 & FRANCE_Basse-Normandie & 10.79 \\
\hline FRC1 & FRANCE_Bourgogne & 9.76 \\
\hline FRE1 & FRANCE_Nord - Pas-de-Calais & 9.55 \\
\hline FRF2 & FRANCE_Lorraine & 9.12 \\
\hline FRF1 & FRANCE_Alsace & 10.40 \\
\hline FRC2 & FRANCE_Franche-Comte & 10.34 \\
\hline FRG0 & FRANCE_Pays de la Loire & 10.04 \\
\hline FRHO & FRANCE_Bretagne & 8.69 \\
\hline FRI3 & FRANCE_Poitou-Charentes & 9.65 \\
\hline FRI1 & FRANCE_Aquitaine & 8.91 \\
\hline FRJ2 & FRANCE_Midi-Pyrenees & 9.53 \\
\hline FRI2 & FRANCE_Limousin & 10.19 \\
\hline FRK2 & FRANCE_Rhone-Alpes & 11.84 \\
\hline FRK1 & FRANCE_Auvergne & 11.01 \\
\hline FRJ1 & FRANCE_Languedoc-Roussillon & 10.15 \\
\hline FRL0 & FRANCE_Provence-Alpes-Cote d Azur & 12.04 \\
\hline FRM0 & FRANCE_Corse & 12.71 \\
\hline EL30 & GREECE_Anatoliki Makedonia Thraki & 7.52 \\
\hline EL41 & GREECE_Kentriki Makedonia & 7.06 \\
\hline EL42 & GREECE_Dytiki Makedonia & 7.17 \\
\hline EL43 & GREECE_Thessalia & 6.71 \\
\hline EL51 & GREECE_Ipeiros & 6.63 \\
\hline EL52 & GREECE_Ionia Nisia & 8.03 \\
\hline EL53 & GREECE_Dytiki Ellada & 6.63 \\
\hline EL54 & GREECE_Sterea Ellada & 6.67 \\
\hline EL61 & GREECE_Peloponnisos & 7.15 \\
\hline EL62 & GREECE_Attiki & 8.67 \\
\hline EL63 & GREECE_Voreio Aigaio & 7.04 \\
\hline EL64 & GREECE_Notio Aigaio & 8.37 \\
\hline EL65 & GREECE_Kriti & 7.60 \\
\hline HU11 & HUNGARY_Kozep-Magyarorszag & 29.07 \\
\hline HU21 & HUNGARY_Kozep-Dunantul & 26.45 \\
\hline HU22 & HUNGARY_Nyugat-Dunantul & 26.91 \\
\hline HU23 & HUNGARY_Del-Dunantul & 23.16 \\
\hline HU31 & HUNGARY_eszak-Magyarorszag & 24.32 \\
\hline HU32 & HUNGARY_eszak-Alfold & 24.09 \\
\hline HU33 & HUNGARY_Del-Alfold & 24.25 \\
\hline IE04 & IRELAND_Border Midlands & 31.97 \\
\hline IE05 & IRELAND_Southern and Eastern & 37.38 \\
\hline ITC1 & ITALY_Piemonte & 12.31 \\
\hline ITC2 & ITALY_Valle dAosta Vallee dAoste & 7.47 \\
\hline ITC3 & ITALY_Liguria & 7.46 \\
\hline ITC4 & ITALY_Lombardia & 10.80 \\
\hline
\end{tabular}




\begin{tabular}{|c|c|c|}
\hline ITH1 & ITALY_Bolzano-Bozen & 6.13 \\
\hline ITH2 & ITALY_Provincia Autonoma Trento & 8.16 \\
\hline ITH3 & ITALY_Veneto & 10.37 \\
\hline ITH4 & ITALY_Friuli-Venezia Giulia & 8.97 \\
\hline ITH5 & ITALY_Emilia-Romagna & 10.21 \\
\hline ITI1 & ITALY_Toscana & 10.18 \\
\hline ITI2 & ITALY_Umbria & 8.59 \\
\hline ITI3 & ITALY_Marche & 9.71 \\
\hline ITI4 & ITALY_Lazio & 10.07 \\
\hline ITF1 & ITALY_Abruzzo & 8.56 \\
\hline ITF2 & ITALY_Molise & 8.09 \\
\hline ITF3 & ITALY_Campania & 8.94 \\
\hline ITF4 & ITALY_Puglia & 8.67 \\
\hline ITF5 & ITALY_Basilicata & 8.22 \\
\hline ITF6 & ITALY_Calabria & 10.03 \\
\hline ITG1 & ITALY_Sicilia & 9.96 \\
\hline ITG2 & ITALY_Sardegna & 10.76 \\
\hline LT01 & LITHUANIA_Lietuva & 20.84 \\
\hline LU00 & LUXEMBOURG_Luxembourg (Grand-D) & 46.49 \\
\hline LV00 & LATVIA_Latvija & 17.29 \\
\hline MT00 & MALTA_Malta & 30.25 \\
\hline NL11 & NETHERLANDS_Groningen & 28.97 \\
\hline NL12 & NETHERLANDS_Friesland & 24.27 \\
\hline NL13 & NETHERLANDS_Drenthe & 25.28 \\
\hline NL21 & NETHERLANDS_Overijssel & 25.30 \\
\hline NL22 & NETHERLANDS_Gelderland & 20.31 \\
\hline NL23 & NETHERLANDS_Flevoland & 26.90 \\
\hline NL31 & NETHERLANDS_Utrecht & 20.92 \\
\hline NL32 & NETHERLANDS_Noord-Holland & 23.46 \\
\hline NL33 & NETHERLANDS_Zuid-Holland & 27.07 \\
\hline NL34 & NETHERLANDS_Zeeland & 27.78 \\
\hline NL41 & NETHERLANDS_Noord-Brabant & 24.47 \\
\hline NL42 & NETHERLANDS_Limburg (NL) & 22.73 \\
\hline PL71 & POLAND_Lódzkie & 15.04 \\
\hline PL92 & POLAND_Mazowieckie & 17.00 \\
\hline PL21 & POLAND_Malopolskie & 15.16 \\
\hline PL22 & POLAND_Slaskie & 15.70 \\
\hline PL81 & POLAND_Lubelskie & 16.08 \\
\hline PL82 & POLAND_Podkarpackie & 15.13 \\
\hline PL72 & POLAND_Swietokrzyskie & 15.79 \\
\hline PL84 & POLAND_Podlaskie & 15.85 \\
\hline PL41 & POLAND_Wielkopolskie & 16.65 \\
\hline PL42 & POLAND_Zachodniopomorskie & 14.63 \\
\hline PL43 & POLAND_Lubuskie & 15.68 \\
\hline PL51 & POLAND_Dolnoslaskie & 16.01 \\
\hline PL52 & POLAND_Opolskie & 15.68 \\
\hline PL61 & POLAND_Kujawsko-Pomorskie & 14.97 \\
\hline PL62 & POLAND_Warminsko-Mazurskie & 16.17 \\
\hline PL63 & POLAND_Pomorskie & 15.58 \\
\hline PT11 & PORTUGAL_Norte & 10.48 \\
\hline
\end{tabular}




\begin{tabular}{|c|c|c|}
\hline PT15 & PORTUGAL_Algarve & 9.90 \\
\hline PT16 & PORTUGAL_Centro (PT) & 10.63 \\
\hline PT17 & PORTUGAL_Lisboa & 10.73 \\
\hline PT18 & PORTUGAL_Alentejo & 10.94 \\
\hline SE11 & SWEDEN_Stockholm & 22.17 \\
\hline SE12 & SWEDEN_ostra Mellansverige & 21.12 \\
\hline SE22 & SWEDEN_Sydsverige & 22.91 \\
\hline SE31 & SWEDEN_Norra Mellansverige & 16.53 \\
\hline SE32 & SWEDEN_Mellersta Norrland & 12.28 \\
\hline SE33 & SWEDEN_ovre Norrland & 18.77 \\
\hline SE21 & SWEDEN_Småland med oarna & 23.85 \\
\hline SE23 & SWEDEN_Västsverige & 25.62 \\
\hline SI03 & SLOVENIA_Slovenija & 19.77 \\
\hline SK01 & SLOVAKIA_Bratislavský kraj & 24.30 \\
\hline SK02 & SLOVAKIA_Zapadne Slovensko & 22.63 \\
\hline SK03 & SLOVAKIA_Stredne Slovensko & 21.13 \\
\hline SK04 & SLOVAKIA_Východne Slovensko & 20.91 \\
\hline $\mathrm{UKC1}$ & UK_Tees Valley and Durham & 14.62 \\
\hline $\mathrm{UKC} 2$ & UK_Northumberland Tyne and Wear & 14.65 \\
\hline UKD1 & UK_Cumbria & 17.26 \\
\hline UKD3 & UK_Cheshire & 16.10 \\
\hline UKD4 & UK_Greater Manchester & 14.56 \\
\hline UKD6 & UK_Lancashire & 16.97 \\
\hline UKD7 & UK_Merseyside & 13.61 \\
\hline UKE1 & UK_East Riding, North Lincolnshire & 17.29 \\
\hline UKE2 & UK_North Yorkshire & 15.89 \\
\hline UKE3 & UK_South Yorkshire & 14.32 \\
\hline UKE4 & UK_West Yorkshire & 14.76 \\
\hline UKF1 & UK_Derbyshire and Nottinghamshire & 14.45 \\
\hline UKF2 & UK_Leicestershire Rutland & 17.90 \\
\hline UKF3 & UK_Lincolnshire & 15.54 \\
\hline UKG1 & UK_Herefordshire Worcestershire & 16.84 \\
\hline UKG2 & UK_Shropshire and Staffordshire & 16.64 \\
\hline UKG3 & UK_West Midlands & 15.00 \\
\hline UKH1 & UK_East Anglia & 14.48 \\
\hline $\mathrm{UKH} 2$ & UK_Bedfordshire Hertfordshire & 13.58 \\
\hline UKH3 & UK_Essex & 14.39 \\
\hline UKI4 & UK_Inner London & 14.60 \\
\hline UKI5 & UK_Outer London & 12.37 \\
\hline UKJ1 & UK_Berkshire Bucks Oxfordshire & 15.18 \\
\hline UKJ2 & UK_Surrey East and West Sussex & 14.14 \\
\hline UKJ3 & UK_Hampshire and Isle of Wight & 18.34 \\
\hline UKJ4 & UK_Kent & 16.56 \\
\hline UKK1 & UK_Gloucestershire Wiltshire & 19.57 \\
\hline UKK2 & UK_Dorset and Somerset & 16.34 \\
\hline UKK3 & UK_Cornwall and Isles of Scilly & 15.83 \\
\hline UKK4 & UK_Devon & 16.29 \\
\hline UKL1 & UK_West Wales and The Valleys & 13.63 \\
\hline UKL2 & UK_East Wales & 13.08 \\
\hline UKM5 & UK_North Eastern Scotland & 10.72 \\
\hline
\end{tabular}


UKM7 UK_Eastern Scotland

12.59

UKM8 UK_South Western Scotland

15.24

UKM6 UK_Highlands and Islands

12.42

UKN0 UK_Northern Ireland

14.36 
Table B.2. Output losses due to an interruption of extra-EU GVCs (Figure 4)

\begin{tabular}{|c|c|c|}
\hline$\overline{\mathrm{CODE}}$ & COUNTRY_REGION & $\begin{array}{c}\text { Output Losses } \\
\text { (percentage) }\end{array}$ \\
\hline AT11 & AUSTRIA_Burgenland & 9.35 \\
\hline AT12 & AUSTRIA_Niederosterreich & 9.59 \\
\hline AT13 & AUSTRIA_Wien & 9.81 \\
\hline AT21 & AUSTRIA_Karnten & 9.93 \\
\hline AT22 & AUSTRIA_Steiermark & 9.67 \\
\hline AT31 & AUSTRIA_Oberosterreich & 10.27 \\
\hline AT32 & AUSTRIA_Salzburg & 9.91 \\
\hline AT33 & AUSTRIA_Tirol & 10.41 \\
\hline AT34 & AUSTRIA_Vorarlberg & 10.33 \\
\hline BE10 & BELGIUM_Region de Bruxelles & 11.16 \\
\hline BE21 & BELGIUM_Prov. Antwerpen & 11.70 \\
\hline BE22 & BELGIUM_Prov. Limburg (B) & 11.26 \\
\hline BE23 & BELGIUM_Prov. Oost-Vlaanderen & 10.11 \\
\hline BE24 & BELGIUM_Prov. Vlaams Brabant & 10.68 \\
\hline BE25 & BELGIUM_Prov. West-Vlaanderen & 10.93 \\
\hline BE31 & BELGIUM_Prov. Brabant Wallon & 11.92 \\
\hline BE32 & BELGIUM_Prov. Hainaut & 9.68 \\
\hline BE33 & BELGIUM_Prov. Liege & 11.03 \\
\hline BE34 & BELGIUM_Prov. Luxembourg (B) & 10.41 \\
\hline BE35 & BELGIUM_Prov. Namur & 10.88 \\
\hline CZ01 & CZECH REPUBLIC_Praha & 9.63 \\
\hline $\mathrm{CZ02}$ & CZECH REPUBLIC_Stredni Cechy & 9.68 \\
\hline CZ03 & CZECH REPUBLIC_Jihozapad & 9.49 \\
\hline CZ04 & CZECH REPUBLIC_Severozapad & 9.10 \\
\hline CZ05 & CZECH REPUBLIC_Severovychod & 9.55 \\
\hline CZ06 & CZECH REPUBLIC_Jihovychod & 9.53 \\
\hline CZ07 & CZECH REPUBLIC_Stredni Morava & 9.32 \\
\hline CZ08 & CZECH REPUBLIC_Moravskoslezko & 9.66 \\
\hline DE11 & GERMANY_Stuttgart & 6.85 \\
\hline DE12 & GERMANY_Karlsruhe & 6.38 \\
\hline DE13 & GERMANY_Freiburg & 5.95 \\
\hline DE14 & GERMANY_Tubingen & 6.27 \\
\hline DE21 & GERMANY_Oberbayern & 6.89 \\
\hline DE22 & GERMANY_Niederbayern & 5.93 \\
\hline DE23 & GERMANY_Oberpfalz & 5.96 \\
\hline DE24 & GERMANY_Oberfranken & 5.55 \\
\hline DE25 & GERMANY_Mittelfranken & 5.85 \\
\hline DE26 & GERMANY_Unterfranken & 5.94 \\
\hline DE27 & GERMANY_Schwaben & 5.91 \\
\hline DE30 & GERMANY_Berlin & 6.75 \\
\hline DE40 & GERMANY_Brandenburg - Nordost & 6.17 \\
\hline DE50 & GERMANY_Bremen & 6.05 \\
\hline DE60 & GERMANY_Hamburg & 5.65 \\
\hline DE71 & GERMANY_Darmstadt & 7.02 \\
\hline DE72 & GERMANY_Giessen & 5.66 \\
\hline
\end{tabular}




\begin{tabular}{|c|c|c|}
\hline DE73 & GERMANY_Kassel & 5.76 \\
\hline DE80 & GERMANY_Mecklenburg-Vorpommern & 6.03 \\
\hline DE91 & GERMANY_Braunschweig & 6.25 \\
\hline DE92 & GERMANY_Hannover & 6.02 \\
\hline DE93 & GERMANY_Luneburg & 5.11 \\
\hline DE94 & GERMANY_Weser-Ems & 5.94 \\
\hline DEA1 & GERMANY_Dusseldorf & 4.89 \\
\hline DEA2 & GERMANY_Koln & 5.26 \\
\hline DEA3 & GERMANY_Munster & 5.19 \\
\hline DEA4 & GERMANY_Detmold & 6.01 \\
\hline DEA5 & GERMANY_Arnsberg & 5.08 \\
\hline DEB1 & GERMANY_Koblenz & 5.63 \\
\hline DEB2 & GERMANY_Trier & 5.24 \\
\hline DEB3 & GERMANY_Rheinhessen-Pfalz & 5.19 \\
\hline DEC0 & GERMANY_Saarland & 5.86 \\
\hline DED2 & GERMANY_Chemnitz & 5.81 \\
\hline DED4 & GERMANY_Dresden & 6.44 \\
\hline DED5 & GERMANY_Leipzig & 6.09 \\
\hline DEE0 & GERMANY_Sachsen-Anhalt & 5.49 \\
\hline DEF0 & GERMANY_Schleswig-Holstein & 5.02 \\
\hline DEG0 & GERMANY_Thüringen & 6.01 \\
\hline DK01 & DENMARK_Hovedstadsreg & 11.06 \\
\hline DK02 & DENMARK_Ost for Storebælt & 10.65 \\
\hline DK03 & DENMARK_West_for_Storebelt & 11.04 \\
\hline EE00 & ESTONIA_Eesti & 18.13 \\
\hline ES11 & SPAIN_Galicia & 4.84 \\
\hline ES12 & SPAIN_Principado de Asturias & 4.68 \\
\hline ES13 & SPAIN_Cantabria & 5.37 \\
\hline ES21 & SPAIN_Pais Vasco & 6.16 \\
\hline ES22 & SPAIN_Foral de Navarra & 5.68 \\
\hline ES23 & SPAIN_La Rioja & 5.52 \\
\hline ES24 & SPAIN_Aragon & 5.50 \\
\hline ES30 & SPAIN_Comunidad de Madrid & 6.40 \\
\hline ES41 & SPAIN_Castilla y Leon & 4.42 \\
\hline ES42 & SPAIN_Castilla-la Mancha & 5.01 \\
\hline ES43 & SPAIN_Extremadura & 5.56 \\
\hline ES51 & SPAIN_Cataluna & 5.72 \\
\hline ES52 & SPAIN_Comunidad Valenciana & 4.85 \\
\hline ES53 & SPAIN_Illes Balears & 4.70 \\
\hline ES61 & SPAIN_Andalucia & 3.20 \\
\hline ES62 & SPAIN_Region de Murcia & 5.51 \\
\hline ES63 & SPAIN_Ceuta (ES) & 5.64 \\
\hline ES64 & SPAIN_Melilla (ES) & 5.72 \\
\hline ES70 & SPAIN_Canarias_ES & 4.27 \\
\hline FI19 & FINALND_Ita-Suomi & 15.85 \\
\hline FI1B & FINALND_Etela-Suomi & 13.78 \\
\hline FI1C & FINALND_Lansi-Suomi & 15.27 \\
\hline FI1D & FINALND_Pohjois-Suomi & 16.68 \\
\hline FI20 & FINALND_Aland & 14.00 \\
\hline FR10 & FRANCE_Ile de France & 3.66 \\
\hline
\end{tabular}




\begin{tabular}{|c|c|c|}
\hline FRF2 & FRANCE_Champagne-Ardenne & 4.02 \\
\hline FRE2 & FRANCE_Picardie & 3.28 \\
\hline FRD2 & FRANCE_Haute-Normandie & 3.89 \\
\hline FRB0 & FRANCE_Centre & 3.52 \\
\hline FRD1 & FRANCE_Basse-Normandie & 4.02 \\
\hline FRC1 & FRANCE_Bourgogne & 3.35 \\
\hline FRE1 & FRANCE_Nord - Pas-de-Calais & 3.80 \\
\hline FRF2 & FRANCE_Lorraine & 3.41 \\
\hline FRF1 & FRANCE_Alsace & 3.65 \\
\hline FRC2 & FRANCE_Franche-Comte & 3.49 \\
\hline FRG0 & FRANCE_Pays de la Loire & 3.85 \\
\hline FRH0 & FRANCE_Bretagne & 3.44 \\
\hline FRI3 & FRANCE_Poitou-Charentes & 3.77 \\
\hline FRI1 & FRANCE_Aquitaine & 3.40 \\
\hline FRJ2 & FRANCE_Midi-Pyrenees & 3.66 \\
\hline FRI2 & FRANCE_Limousin & 3.59 \\
\hline FRK2 & FRANCE_Rhone-Alpes & 4.72 \\
\hline FRK1 & FRANCE_Auvergne & 3.72 \\
\hline FRJ1 & FRANCE_Languedoc-Roussillon & 4.41 \\
\hline FRLO & FRANCE_Provence-Alpes-Cote d Azur & 5.38 \\
\hline FRM0 & FRANCE_Corse & 5.89 \\
\hline EL30 & GREECE_Anatoliki Makedonia Thraki & 6.44 \\
\hline EL41 & GREECE_Kentriki Makedonia & 5.97 \\
\hline EL42 & GREECE_Dytiki Makedonia & 6.07 \\
\hline EL43 & GREECE_Thessalia & 5.79 \\
\hline EL51 & GREECE_Ipeiros & 5.55 \\
\hline EL52 & GREECE_Ionia Nisia & 6.80 \\
\hline EL53 & GREECE_Dytiki Ellada & 5.73 \\
\hline EL54 & GREECE_Sterea Ellada & 5.68 \\
\hline EL61 & GREECE_Peloponnisos & 5.99 \\
\hline EL62 & GREECE_Attiki & 7.50 \\
\hline EL63 & GREECE_Voreio Aigaio & 5.74 \\
\hline EL64 & GREECE_Notio Aigaio & 7.13 \\
\hline EL65 & GREECE_Kriti & 6.50 \\
\hline HU11 & HUNGARY_Kozep-Magyarorszag & 15.52 \\
\hline HU21 & HUNGARY_Kozep-Dunantul & 13.30 \\
\hline HU22 & HUNGARY_Nyugat-Dunantul & 13.28 \\
\hline HU23 & HUNGARY_Del-Dunantul & 11.43 \\
\hline HU31 & HUNGARY_eszak-Magyarorszag & 12.51 \\
\hline HU32 & HUNGARY_eszak-Alfold & 12.45 \\
\hline HU33 & HUNGARY_Del-Alfold & 12.12 \\
\hline IE04 & IRELAND_Border Midlands & 22.01 \\
\hline IE05 & IRELAND_Southern and Eastern & 25.85 \\
\hline ITC1 & ITALY_Piemonte & 5.68 \\
\hline ITC2 & ITALY_Valle dAosta Vallee dAoste & 3.58 \\
\hline ITC3 & ITALY_Liguria & 3.37 \\
\hline ITC4 & ITALY_Lombardia & 4.66 \\
\hline ITH1 & ITALY_Bolzano-Bozen & 2.78 \\
\hline ITH2 & ITALY_Provincia Autonoma Trento & 3.53 \\
\hline ITH3 & ITALY_Veneto & 4.39 \\
\hline
\end{tabular}




\begin{tabular}{|c|c|c|}
\hline ITH4 & ITALY_Friuli-Venezia Giulia & 3.85 \\
\hline ITH5 & ITALY_Emilia-Romagna & 4.27 \\
\hline ITI1 & ITALY_Toscana & 4.54 \\
\hline ITI2 & ITALY_Umbria & 3.89 \\
\hline ITI3 & ITALY_Marche & 4.27 \\
\hline ITI4 & ITALY_Lazio & 4.56 \\
\hline ITF1 & ITALY_Abruzzo & 3.68 \\
\hline ITF2 & ITALY_Molise & 3.44 \\
\hline ITF3 & ITALY_Campania & 3.98 \\
\hline ITF4 & ITALY_Puglia & 3.82 \\
\hline ITF5 & ITALY_Basilicata & 3.75 \\
\hline ITF6 & ITALY_Calabria & 4.92 \\
\hline ITG1 & ITALY_Sicilia & 5.00 \\
\hline ITG2 & ITALY_Sardegna & 5.22 \\
\hline LT01 & LITHUANIA_Lietuva & 15.58 \\
\hline LU00 & LUXEMBOURG_Luxembourg (Grand-D) & 28.59 \\
\hline LV00 & LATVIA_Latvija & 12.43 \\
\hline MT00 & MALTA_Malta & 22.73 \\
\hline NL11 & NETHERLANDS_Groningen & 11.21 \\
\hline NL12 & NETHERLANDS_Friesland & 9.49 \\
\hline NL13 & NETHERLANDS_Drenthe & 9.11 \\
\hline NL21 & NETHERLANDS_Overijssel & 9.26 \\
\hline NL22 & NETHERLANDS_Gelderland & 8.48 \\
\hline NL23 & NETHERLANDS_Flevoland & 9.86 \\
\hline NL31 & NETHERLANDS_Utrecht & 8.64 \\
\hline NL32 & NETHERLANDS_Noord-Holland & 9.49 \\
\hline NL33 & NETHERLANDS_Zuid-Holland & 10.42 \\
\hline NL34 & NETHERLANDS_Zeeland & 10.56 \\
\hline NL41 & NETHERLANDS_Noord-Brabant & 9.81 \\
\hline NL42 & NETHERLANDS_Limburg (NL) & 8.84 \\
\hline PL71 & POLAND_Lódzkie & 7.23 \\
\hline PL92 & POLAND_Mazowieckie & 8.36 \\
\hline PL21 & POLAND_Malopolskie & 7.42 \\
\hline PL22 & POLAND_Slaskie & 7.55 \\
\hline PL81 & POLAND_Lubelskie & 7.79 \\
\hline PL82 & POLAND_Podkarpackie & 7.45 \\
\hline PL72 & POLAND_Swietokrzyskie & 7.52 \\
\hline PL84 & POLAND_Podlaskie & 7.72 \\
\hline PL41 & POLAND_Wielkopolskie & 7.84 \\
\hline PL42 & POLAND_Zachodniopomorskie & 6.78 \\
\hline PL43 & POLAND_Lubuskie & 7.22 \\
\hline PL51 & POLAND_Dolnoslaskie & 7.99 \\
\hline PL52 & POLAND_Opolskie & 7.15 \\
\hline PL61 & POLAND_Kujawsko-Pomorskie & 7.06 \\
\hline PL62 & POLAND_Warminsko-Mazurskie & 7.70 \\
\hline PL63 & POLAND_Pomorskie & 7.46 \\
\hline PT11 & PORTUGAL_Norte & 5.99 \\
\hline PT15 & PORTUGAL_Algarve & 6.07 \\
\hline PT16 & PORTUGAL_Centro (PT) & 5.99 \\
\hline PT17 & PORTUGAL_Lisboa & 6.25 \\
\hline
\end{tabular}


SK04 SLOVAKIA_Východne Slovensko 8.45

UKC1 UK_Tees Valley and Durham $\quad 7.59$

UKC2 UK_Northumberland Tyne and Wear $\quad 7.47$

UKD1 UK_Cumbria $\quad 8.08$

UKD3 UK_Cheshire $\quad 7.79$

UKD4 UK_Greater Manchester 7.76

UKD6 UK_Lancashire $\quad 8.44$

UKD7 UK_Merseyside 7.54

UKE1 UK_East Riding, North Lincolnshire 8.36

UKE2 UK_North Yorkshire 8.26

UKE3 UK_South Yorkshire 7.28

UKE4 UK_West Yorkshire $\quad 7.58$

UKF1 UK_Derbyshire and Nottinghamshire $\quad 7.53$

UKF2 UK_Leicestershire Rutland 9.26

UKF3 UK_Lincolnshire $\quad 8.27$

UKG1 UK_Herefordshire Worcestershire $\quad 8.68$

UKG2 UK_Shropshire and Staffordshire $\quad 8.77$

UKG3 UK_West Midlands $\quad 7.53$

UKH1 UK_East Anglia $\quad 7.59$

UKH2 UK_Bedfordshire Hertfordshire 6.98

$\begin{array}{lll}\text { UKH3 UK_Essex } & 7.18\end{array}$

UKI4 UK_Inner London $\quad 8.38$

UKI5 UK_Outer London 6.33

UKJ1 UK_Berkshire Bucks Oxfordshire $\quad 7.84$

UKJ2 UK_Surrey East and West Sussex 7.27

UKJ3 UK_Hampshire and Isle of Wight 9.89

UKJ4 UK_Kent 8.51

UKK1 UK_Gloucestershire Wiltshire 10.64

UKK2 UK_Dorset and Somerset 8.66

UKK3 UK_Cornwall and Isles of Scilly 8.68

UKK4 UK_Devon $\quad 8.77$

UKL1 UK_West Wales and The Valleys 6.75

UKL2 UK_East Wales $\quad 6.16$

UKM5 UK_North Eastern Scotland 4.92

UKM7 UK_Eastern Scotland 5.98

UKM8 UK_South Western Scotland 7.84

UKM6 UK_Highlands and Islands 6.50 
Table B.3. Output losses due to an interruption of EU GVCs (Figure 5)

\begin{tabular}{|c|c|c|}
\hline$\overline{\mathrm{CODE}}$ & COUNTRY_REGION & $\begin{array}{c}\text { Output Losses } \\
\text { (percentage) }\end{array}$ \\
\hline AT11 & AUSTRIA_Burgenland & 10.66 \\
\hline AT12 & AUSTRIA_Niederosterreich & 11.53 \\
\hline AT13 & AUSTRIA_Wien & 11.03 \\
\hline AT21 & AUSTRIA_Karnten & 11.53 \\
\hline AT22 & AUSTRIA_Steiermark & 11.50 \\
\hline AT31 & AUSTRIA_Oberosterreich & 11.70 \\
\hline AT32 & AUSTRIA_Salzburg & 11.48 \\
\hline AT33 & AUSTRIA_Tirol & 11.60 \\
\hline AT34 & AUSTRIA_Vorarlberg & 12.87 \\
\hline BE10 & BELGIUM_Region de Bruxelles & 13.73 \\
\hline BE21 & BELGIUM_Prov. Antwerpen & 17.33 \\
\hline BE22 & BELGIUM_Prov. Limburg (B) & 17.38 \\
\hline BE23 & BELGIUM_Prov. Oost-Vlaanderen & 15.04 \\
\hline BE24 & BELGIUM_Prov. Vlaams Brabant & 16.68 \\
\hline BE25 & BELGIUM_Prov. West-Vlaanderen & 16.97 \\
\hline BE31 & BELGIUM_Prov. Brabant Wallon & 17.66 \\
\hline BE32 & BELGIUM_Prov. Hainaut & 14.78 \\
\hline BE33 & BELGIUM_Prov. Liege & 15.98 \\
\hline BE34 & BELGIUM_Prov. Luxembourg (B) & 16.50 \\
\hline BE35 & BELGIUM_Prov. Namur & 14.52 \\
\hline CZ01 & CZECH REPUBLIC_Praha & 14.59 \\
\hline $\mathrm{CZ02}$ & CZECH REPUBLIC_Stredni Cechy & 16.60 \\
\hline CZ03 & CZECH REPUBLIC_Jihozapad & 15.98 \\
\hline CZ04 & CZECH REPUBLIC_Severozapad & 15.39 \\
\hline CZ05 & CZECH REPUBLIC_Severovychod & 16.31 \\
\hline CZ06 & CZECH REPUBLIC_Jihovychod & 16.01 \\
\hline CZ07 & CZECH REPUBLIC_Stredni Morava & 15.98 \\
\hline CZ08 & CZECH REPUBLIC_Moravskoslezko & 16.35 \\
\hline DE11 & GERMANY_Stuttgart & 13.02 \\
\hline DE12 & GERMANY_Karlsruhe & 12.54 \\
\hline DE13 & GERMANY_Freiburg & 12.14 \\
\hline DE14 & GERMANY_Tubingen & 12.56 \\
\hline DE21 & GERMANY_Oberbayern & 12.60 \\
\hline DE22 & GERMANY_Niederbayern & 12.12 \\
\hline DE23 & GERMANY_Oberpfalz & 12.59 \\
\hline DE24 & GERMANY_Oberfranken & 12.00 \\
\hline DE25 & GERMANY_Mittelfranken & 12.27 \\
\hline DE26 & GERMANY_Unterfranken & 12.25 \\
\hline DE27 & GERMANY_Schwaben & 11.98 \\
\hline DE30 & GERMANY_Berlin & 10.91 \\
\hline DE40 & GERMANY_Brandenburg - Nordost & 10.79 \\
\hline DE50 & GERMANY_Bremen & 12.39 \\
\hline DE60 & GERMANY_Hamburg & 10.58 \\
\hline DE71 & GERMANY_Darmstadt & 12.37 \\
\hline DE72 & GERMANY_Giessen & 11.83 \\
\hline
\end{tabular}




\begin{tabular}{|c|c|c|}
\hline DE73 & GERMANY_Kassel & 11.69 \\
\hline DE80 & GERMANY_Mecklenburg-Vorpommern & 9.86 \\
\hline DE91 & GERMANY_Braunschweig & 12.45 \\
\hline DE92 & GERMANY_Hannover & 11.55 \\
\hline DE93 & GERMANY_Luneburg & 9.60 \\
\hline DE94 & GERMANY_Weser-Ems & 11.34 \\
\hline DEA1 & GERMANY_Dusseldorf & 10.63 \\
\hline DEA2 & GERMANY_Koln & 10.75 \\
\hline DEA3 & GERMANY_Munster & 10.36 \\
\hline DEA4 & GERMANY_Detmold & 11.86 \\
\hline DEA5 & GERMANY_Arnsberg & 10.99 \\
\hline DEB1 & GERMANY_Koblenz & 11.13 \\
\hline DEB2 & GERMANY_Trier & 10.18 \\
\hline DEB3 & GERMANY_Rheinhessen-Pfalz & 10.77 \\
\hline DEC0 & GERMANY_Saarland & 12.49 \\
\hline DED2 & GERMANY_Chemnitz & 10.52 \\
\hline DED4 & GERMANY_Dresden & 11.73 \\
\hline DED5 & GERMANY_Leipzig & 10.22 \\
\hline DEE0 & GERMANY_Sachsen-Anhalt & 10.14 \\
\hline DEF0 & GERMANY_Schleswig-Holstein & 10.44 \\
\hline DEG0 & GERMANY_Thüringen & 11.16 \\
\hline DK01 & DENMARK_Hovedstadsreg & 8.21 \\
\hline DK02 & DENMARK_Ost for Storebælt & 8.36 \\
\hline DK03 & DENMARK_West_for_Storebelt & 8.56 \\
\hline EE00 & ESTONIA_Eesti & 6.82 \\
\hline ES11 & SPAIN_Galicia & 3.91 \\
\hline ES12 & SPAIN_Principado de Asturias & 4.40 \\
\hline ES13 & SPAIN_Cantabria & 4.88 \\
\hline ES21 & SPAIN_Pais Vasco & 5.30 \\
\hline ES22 & SPAIN_Foral de Navarra & 4.97 \\
\hline ES23 & SPAIN_La Rioja & 5.10 \\
\hline ES24 & SPAIN_Aragon & 4.56 \\
\hline ES30 & SPAIN_Comunidad de Madrid & 5.72 \\
\hline ES41 & SPAIN_Castilla y Leon & 3.86 \\
\hline ES42 & SPAIN_Castilla-la Mancha & 4.27 \\
\hline ES43 & SPAIN_Extremadura & 4.25 \\
\hline ES51 & SPAIN_Cataluna & 5.48 \\
\hline ES52 & SPAIN_Comunidad Valenciana & 5.04 \\
\hline ES53 & SPAIN_Illes Balears & 3.62 \\
\hline ES61 & SPAIN_Andalucia & 3.25 \\
\hline ES62 & SPAIN_Region de Murcia & 4.99 \\
\hline ES63 & SPAIN_Ceuta (ES) & 3.61 \\
\hline ES64 & SPAIN_Melilla (ES) & 4.00 \\
\hline ES70 & SPAIN_Canarias_ES & 3.41 \\
\hline FI19 & FINALND_Ita-Suomi & 6.15 \\
\hline FI1B & FINALND_Etela-Suomi & 5.47 \\
\hline FI1C & FINALND_Lansi-Suomi & 5.84 \\
\hline FI1D & FINALND_Pohjois-Suomi & 6.88 \\
\hline FI20 & FINALND_Aland & 5.33 \\
\hline FR10 & FRANCE_Ile de France & 5.50 \\
\hline
\end{tabular}




\begin{tabular}{|c|c|c|}
\hline FRF2 & FRANCE_Champagne-Ardenne & 7.30 \\
\hline FRE2 & FRANCE_Picardie & 5.98 \\
\hline FRD2 & FRANCE_Haute-Normandie & 7.59 \\
\hline FRB0 & FRANCE_Centre & 6.07 \\
\hline FRD1 & FRANCE_Basse-Normandie & 6.77 \\
\hline FRC1 & FRANCE_Bourgogne & 6.41 \\
\hline FRE1 & FRANCE_Nord - Pas-de-Calais & 5.75 \\
\hline FRF2 & FRANCE_Lorraine & 5.71 \\
\hline FRF1 & FRANCE_Alsace & 6.75 \\
\hline FRC2 & FRANCE_Franche-Comte & 6.84 \\
\hline FRG0 & FRANCE_Pays de la Loire & 6.19 \\
\hline FRHO & FRANCE_Bretagne & 5.25 \\
\hline FRI3 & FRANCE_Poitou-Charentes & 5.88 \\
\hline FRI1 & FRANCE_Aquitaine & 5.51 \\
\hline FRJ2 & FRANCE_Midi-Pyrenees & 5.87 \\
\hline FRI2 & FRANCE_Limousin & 6.61 \\
\hline FRK2 & FRANCE_Rhone-Alpes & 7.12 \\
\hline FRK1 & FRANCE_Auvergne & 7.29 \\
\hline FRJ1 & FRANCE_Languedoc-Roussillon & 5.74 \\
\hline FRL0 & FRANCE_Provence-Alpes-Cote d Azur & 6.66 \\
\hline FRM0 & FRANCE_Corse & 6.82 \\
\hline EL30 & GREECE_Anatoliki Makedonia Thraki & 1.08 \\
\hline EL41 & GREECE_Kentriki Makedonia & 1.08 \\
\hline EL42 & GREECE_Dytiki Makedonia & 1.09 \\
\hline EL43 & GREECE_Thessalia & 0.92 \\
\hline EL51 & GREECE_Ipeiros & 1.08 \\
\hline EL52 & GREECE_Ionia Nisia & 1.23 \\
\hline EL53 & GREECE_Dytiki Ellada & 0.90 \\
\hline EL54 & GREECE_Sterea Ellada & 0.99 \\
\hline EL61 & GREECE_Peloponnisos & 1.16 \\
\hline EL62 & GREECE_Attiki & 1.17 \\
\hline EL63 & GREECE_Voreio Aigaio & 1.30 \\
\hline EL64 & GREECE_Notio Aigaio & 1.24 \\
\hline EL65 & GREECE_Kriti & 1.10 \\
\hline HU11 & HUNGARY_Kozep-Magyarorszag & 13.5 \\
\hline HU21 & HUNGARY_Kozep-Dunantul & 13.15 \\
\hline HU22 & HUNGARY_Nyugat-Dunantul & 13.63 \\
\hline HU23 & HUNGARY_Del-Dunantul & 11.73 \\
\hline HU31 & HUNGARY_eszak-Magyarorszag & 11.81 \\
\hline HU32 & HUNGARY_eszak-Alfold & 11.64 \\
\hline HU33 & HUNGARY_Del-Alfold & 12.13 \\
\hline IE04 & IRELAND_Border Midlands & 9.96 \\
\hline IE05 & IRELAND_Southern and Eastern & 11.54 \\
\hline ITC1 & ITALY_Piemonte & 6.63 \\
\hline ITC2 & ITALY_Valle dAosta Vallee dAoste & 3.89 \\
\hline ITC3 & ITALY_Liguria & 4.09 \\
\hline ITC4 & ITALY_Lombardia & 6.14 \\
\hline ITH1 & ITALY_Bolzano-Bozen & 3.34 \\
\hline ITH2 & ITALY_Provincia Autonoma Trento & 4.63 \\
\hline ITH3 & ITALY_Veneto & 5.9 \\
\hline
\end{tabular}




\begin{tabular}{|c|c|c|}
\hline ITH4 & ITALY_Friuli-Venezia Giulia & 5.13 \\
\hline ITH5 & ITALY_Emilia-Romagna & 5.94 \\
\hline ITI1 & ITALY_Toscana & 5.64 \\
\hline ITI2 & ITALY_Umbria & 4.70 \\
\hline ITI3 & ITALY_Marche & 5.44 \\
\hline ITI4 & ITALY_Lazio & 5.51 \\
\hline ITF1 & ITALY_Abruzzo & 4.88 \\
\hline ITF2 & ITALY_Molise & 4.66 \\
\hline ITF3 & ITALY_Campania & 4.97 \\
\hline ITF4 & ITALY_Puglia & 4.84 \\
\hline ITF5 & ITALY_Basilicata & 4.47 \\
\hline ITF6 & ITALY_Calabria & 5.11 \\
\hline ITG1 & ITALY_Sicilia & 4.96 \\
\hline ITG2 & ITALY_Sardegna & 5.55 \\
\hline LT01 & LITHUANIA_Lietuva & 5.26 \\
\hline LU00 & LUXEMBOURG_Luxembourg (Grand-D) & 17.90 \\
\hline LV00 & LATVIA_Latvija & 4.86 \\
\hline MT00 & MALTA_Malta & 7.52 \\
\hline NL11 & NETHERLANDS_Groningen & 17.76 \\
\hline NL12 & NETHERLANDS_Friesland & 14.78 \\
\hline NL13 & NETHERLANDS_Drenthe & 16.17 \\
\hline NL21 & NETHERLANDS_Overijssel & 16.04 \\
\hline NL22 & NETHERLANDS_Gelderland & 11.83 \\
\hline NL23 & NETHERLANDS_Flevoland & 17.05 \\
\hline NL31 & NETHERLANDS_Utrecht & 12.27 \\
\hline NL32 & NETHERLANDS_Noord-Holland & 13.97 \\
\hline NL33 & NETHERLANDS_Zuid-Holland & 16.65 \\
\hline NL34 & NETHERLANDS_Zeeland & 17.22 \\
\hline NL41 & NETHERLANDS_Noord-Brabant & 14.66 \\
\hline NL42 & NETHERLANDS_Limburg (NL) & 13.90 \\
\hline PL71 & POLAND_Lódzkie & 7.81 \\
\hline PL92 & POLAND_Mazowieckie & 8.63 \\
\hline PL21 & POLAND_Malopolskie & 7.74 \\
\hline PL22 & POLAND_Slaskie & 8.14 \\
\hline PL81 & POLAND_Lubelskie & 8.29 \\
\hline PL82 & POLAND_Podkarpackie & 7.68 \\
\hline PL72 & POLAND_Swietokrzyskie & 8.26 \\
\hline PL84 & POLAND_Podlaskie & 8.13 \\
\hline PL41 & POLAND_Wielkopolskie & 8.81 \\
\hline PL42 & POLAND_Zachodniopomorskie & 7.85 \\
\hline PL43 & POLAND_Lubuskie & 8.47 \\
\hline PL51 & POLAND_Dolnoslaskie & 8.02 \\
\hline PL52 & POLAND_Opolskie & 8.53 \\
\hline PL61 & POLAND_Kujawsko-Pomorskie & 7.91 \\
\hline PL62 & POLAND_Warminsko-Mazurskie & 8.47 \\
\hline PL63 & POLAND_Pomorskie & 8.12 \\
\hline PT11 & PORTUGAL_Norte & 4.48 \\
\hline PT15 & PORTUGAL_Algarve & 3.82 \\
\hline PT16 & PORTUGAL_Centro (PT) & 4.64 \\
\hline PT17 & PORTUGAL_Lisboa & 4.47 \\
\hline
\end{tabular}


SE12 SWEDEN_ostra Mellansverige 8.97

SE22 SWEDEN_Sydsverige 9.27

SE31 SWEDEN_Norra Mellansverige 6.57

SE32 SWEDEN_Mellersta Norrland 5.31

SE33 SWEDEN_ovre Norrland 7.45

SE21 SWEDEN_Småland med oarna 10.16

SE23 SWEDEN_Västsverige 10.25

SI03 SLOVENIA_Slovenija 6.62

SK01 SLOVAKIA_Bratislavský kraj 13.73

SK02 SLOVAKIA_Zapadne Slovensko 13.49

SK03 SLOVAKIA_Stredne Slovensko 12.48

SK04 SLOVAKIA_Východne Slovensko 12.46

UKC1 UK_Tees Valley and Durham $\quad 7.03$

UKC2 UK_Northumberland Tyne and Wear $\quad 7.18$

UKD1 UK_Cumbria 9.18

UKD3 UK_Cheshire $\quad 8.31$

UKD4 UK_Greater Manchester 6.80

UKD6 UK_Lancashire $\quad 8.53$

UKD7 UK_Merseyside 6.08

UKE1 UK_East Riding, North Lincolnshire 8.93

UKE2 UK_North Yorkshire 7.62

UKE3 UK_South Yorkshire $\quad 7.04$

UKE4 UK_West Yorkshire 7.18

UKF1 UK_Derbyshire and Nottinghamshire 6.93

UKF2 UK_Leicestershire Rutland 8.64

UKF3 UK_Lincolnshire $\quad 7.27$

UKG1 UK_Herefordshire Worcestershire 8.16

UKG2 UK_Shropshire and Staffordshire $\quad 7.88$

UKG3 UK_West Midlands $\quad 7.47$

UKH1 UK_East Anglia 6.89

UKH2 UK_Bedfordshire Hertfordshire 6.60

UKH3 UK_Essex 1.22

UKI4 UK_Inner London $\quad 6.22$

UKI5 UK_Outer London $\quad 6.04$

UKJ1 UK_Berkshire Bucks Oxfordshire $\quad 7.34$

UKJ2 UK_Surrey East and West Sussex 6.87

UKJ3 UK_Hampshire and Isle of Wight 8.45

UKJ4 UK_Kent 8.05

UKK1 UK_Gloucestershire Wiltshire 8.93

UKK2 UK_Dorset and Somerset 7.68

UKK3 UK_Cornwall and Isles of Scilly 7.15

UKK4 UK_Devon $\quad 7.52$

UKL1 UK_West Wales and The Valleys 6.88

UKL2 UK_East Wales 6.91

UKM5 UK_North Eastern Scotland 5.79

UKM7 UK_Eastern Scotland 6.61

UKM8 UK_South Western Scotland $\quad 7.40$

UKM6 UK_Highlands and Islands 5.93 
Table B.4. Regional change in value-added shares in the back to the past scenario (Figure 7)

\begin{tabular}{|c|c|c|}
\hline$\overline{\mathrm{CODE}}$ & COUNTRY_REGION & $\begin{array}{c}\text { Change } \\
\text { in Value-Added } \\
\text { (percentage) }\end{array}$ \\
\hline$\overline{\mathrm{AT} 11}$ & AUSTRIA_Burgenland & -0.56 \\
\hline AT12 & AUSTRIA_Niederosterreich & -1.06 \\
\hline AT13 & AUSTRIA_Wien & -1.50 \\
\hline AT21 & AUSTRIA_Karnten & -1.01 \\
\hline AT22 & AUSTRIA_Steiermark & -0.71 \\
\hline AT31 & AUSTRIA_Oberosterreich & -1.77 \\
\hline AT32 & AUSTRIA_Salzburg & -2.50 \\
\hline AT33 & AUSTRIA_Tirol & -1.03 \\
\hline AT34 & AUSTRIA_Vorarlberg & -3.94 \\
\hline BE10 & BELGIUM_Region de Bruxelles & 1.54 \\
\hline BE21 & BELGIUM_Prov. Antwerpen & 1.92 \\
\hline BE22 & BELGIUM_Prov. Limburg (B) & 0.55 \\
\hline BE23 & BELGIUM_Prov. Oost-Vlaanderen & -1.32 \\
\hline BE24 & BELGIUM_Prov. Vlaams Brabant & -0.95 \\
\hline BE25 & BELGIUM_Prov. West-Vlaanderen & 2.34 \\
\hline BE31 & BELGIUM_Prov. Brabant Wallon & -8.31 \\
\hline BE32 & BELGIUM_Prov. Hainaut & 3.09 \\
\hline BE33 & BELGIUM_Prov. Liege & 0.99 \\
\hline BE34 & BELGIUM_Prov. Luxembourg (B) & 1.56 \\
\hline BE35 & BELGIUM_Prov. Namur & 0.01 \\
\hline CZ01 & CZECH REPUBLIC_Praha & -11.01 \\
\hline $\mathrm{CZ02}$ & CZECH REPUBLIC_Stredni Cechy & -6.78 \\
\hline $\mathrm{CZ} 03$ & CZECH REPUBLIC_Jihozapad & -3.70 \\
\hline $\mathrm{CZ04}$ & CZECH REPUBLIC_Severozapad & 1.33 \\
\hline CZ05 & CZECH REPUBLIC_Severovychod & -1.02 \\
\hline CZ06 & CZECH REPUBLIC_Jihovychod & -5.97 \\
\hline $\mathrm{CZ07}$ & CZECH REPUBLIC_Stredni Morava & -4.23 \\
\hline CZ08 & CZECH REPUBLIC_Moravskoslezko & -5.07 \\
\hline DE11 & GERMANY_Stuttgart & -1.22 \\
\hline DE12 & GERMANY_Karlsruhe & -0.84 \\
\hline DE13 & GERMANY_Freiburg & 0.54 \\
\hline DE14 & GERMANY_Tubingen & -3.02 \\
\hline DE21 & GERMANY_Oberbayern & -0.71 \\
\hline DE22 & GERMANY_Niederbayern & -5.07 \\
\hline DE23 & GERMANY_Oberpfalz & -2.73 \\
\hline DE24 & GERMANY_Oberfranken & -1.45 \\
\hline DE25 & GERMANY_Mittelfranken & -0.81 \\
\hline DE26 & GERMANY_Unterfranken & -1.20 \\
\hline DE27 & GERMANY_Schwaben & -2.67 \\
\hline DE30 & GERMANY_Berlin & -3.81 \\
\hline DE40 & GERMANY_Brandenburg - Nordost & -5.97 \\
\hline DE50 & GERMANY_Bremen & -1.08 \\
\hline DE60 & GERMANY_Hamburg & 3.01 \\
\hline DE71 & GERMANY_Darmstadt & 2.02 \\
\hline
\end{tabular}




\begin{tabular}{|c|c|c|}
\hline DE72 & GERMANY_Giessen & 0.83 \\
\hline DE73 & GERMANY_Kassel & 1.13 \\
\hline DE80 & GERMANY_Mecklenburg-Vorpommern & -3.85 \\
\hline DE91 & GERMANY_Braunschweig & -1.59 \\
\hline DE92 & GERMANY_Hannover & -2.91 \\
\hline DE93 & GERMANY_Luneburg & 0.17 \\
\hline DE94 & GERMANY_Weser-Ems & -2.38 \\
\hline DEA1 & GERMANY_Dusseldorf & -5.41 \\
\hline DEA2 & GERMANY_Koln & 0.90 \\
\hline DEA3 & GERMANY_Munster & -3.23 \\
\hline DEA4 & GERMANY_Detmold & 1.14 \\
\hline DEA5 & GERMANY_Arnsberg & -0.25 \\
\hline DEB1 & GERMANY_Koblenz & -1.84 \\
\hline DEB2 & GERMANY_Trier & -0.29 \\
\hline DEB3 & GERMANY_Rheinhessen-Pfalz & -0.85 \\
\hline DEC0 & GERMANY_Saarland & 0.10 \\
\hline DED2 & GERMANY_Chemnitz & -3.63 \\
\hline DED4 & GERMANY_Dresden & -5.10 \\
\hline DED5 & GERMANY_Leipzig & -5.73 \\
\hline DEE0 & GERMANY_Sachsen-Anhalt & -4.16 \\
\hline DEF0 & GERMANY_Schleswig-Holstein & 0.75 \\
\hline DEG0 & GERMANY_Thüringen & -5.82 \\
\hline DK01 & DENMARK_Hovedstadsreg & -1.05 \\
\hline DK02 & DENMARK_Ost for Storebælt & 0.86 \\
\hline DK03 & DENMARK_West_for_Storebelt & 1.22 \\
\hline EE00 & ESTONIA_Eesti & 1.75 \\
\hline ES11 & SPAIN_Galicia & -5.63 \\
\hline ES12 & SPAIN_Principado de Asturias & -3.36 \\
\hline ES13 & SPAIN_Cantabria & -1.65 \\
\hline ES21 & SPAIN_Pais Vasco & -36.11 \\
\hline ES22 & SPAIN_Foral de Navarra & -3.29 \\
\hline ES23 & SPAIN_La Rioja & -5.88 \\
\hline ES24 & SPAIN_Aragon & -4.02 \\
\hline ES30 & SPAIN_Comunidad de Madrid & -11.01 \\
\hline ES41 & SPAIN_Castilla y Leon & -2.93 \\
\hline ES42 & SPAIN_Castilla-la Mancha & -4.73 \\
\hline ES43 & SPAIN_Extremadura & -1.88 \\
\hline ES51 & SPAIN_Cataluna & -7.36 \\
\hline ES52 & SPAIN_Comunidad Valenciana & 53.96 \\
\hline ES53 & SPAIN_Illes Balears & -5.09 \\
\hline ES61 & SPAIN_Andalucia & -1.72 \\
\hline ES62 & SPAIN_Region de Murcia & -8.05 \\
\hline ES63 & SPAIN_Ceuta (ES) & -3.33 \\
\hline ES64 & SPAIN_Melilla (ES) & -2.03 \\
\hline ES70 & SPAIN_Canarias_ES & -4.71 \\
\hline FI19 & FINALND_Ita-Suomi & 18.78 \\
\hline FI1B & FINALND_Etela-Suomi & 6.22 \\
\hline FI1C & FINALND_Lansi-Suomi & 7.03 \\
\hline FI1D & FINALND_Pohjois-Suomi & 3.30 \\
\hline FI20 & FINALND_Aland & -2.15 \\
\hline
\end{tabular}




\begin{tabular}{|c|c|c|}
\hline FR10 & FRANCE_Ile de France & -0.15 \\
\hline FRF2 & FRANCE_Champagne-Ardenne & 4.17 \\
\hline FRE2 & FRANCE_Picardie & 3.30 \\
\hline FRD2 & FRANCE_Haute-Normandie & 2.66 \\
\hline FRB0 & FRANCE_Centre & 2.61 \\
\hline FRD1 & FRANCE_Basse-Normandie & 2.55 \\
\hline FRC1 & FRANCE_Bourgogne & 3.65 \\
\hline FRE1 & FRANCE_Nord - Pas-de-Calais & 1.86 \\
\hline FRF2 & FRANCE_Lorraine & 5.32 \\
\hline FRF1 & FRANCE_Alsace & 2.46 \\
\hline FRC2 & FRANCE_Franche-Comte & 5.30 \\
\hline FRG0 & FRANCE_Pays de la Loire & 0.31 \\
\hline FRH0 & FRANCE_Bretagne & 2.02 \\
\hline FRI3 & FRANCE_Poitou-Charentes & 1.67 \\
\hline FRI1 & FRANCE_Aquitaine & 0.63 \\
\hline FRJ2 & FRANCE_Midi-Pyrenees & -0.03 \\
\hline FRI2 & FRANCE_Limousin & 3.82 \\
\hline FRK2 & FRANCE_Rhone-Alpes & -0.71 \\
\hline FRK1 & FRANCE_Auvergne & 2.49 \\
\hline FRJ1 & FRANCE_Languedoc-Roussillon & -0.76 \\
\hline FRL0 & FRANCE_Provence-Alpes-Cote d Azur & -2.04 \\
\hline FRM0 & FRANCE_Corse & -2.28 \\
\hline EL30 & GREECE_Anatoliki Makedonia Thraki & 5.22 \\
\hline EL41 & GREECE_Kentriki Makedonia & 14.59 \\
\hline EL42 & GREECE_Dytiki Makedonia & -4.22 \\
\hline EL43 & GREECE_Thessalia & 11.65 \\
\hline EL51 & GREECE_Ipeiros & 13.44 \\
\hline EL52 & GREECE_Ionia Nisia & 2.47 \\
\hline EL53 & GREECE_Dytiki Ellada & 8.96 \\
\hline EL54 & GREECE_Sterea Ellada & 13.85 \\
\hline EL61 & GREECE_Peloponnisos & 24.44 \\
\hline EL62 & GREECE_Attiki & -3.99 \\
\hline EL63 & GREECE_Voreio Aigaio & 6.78 \\
\hline EL64 & GREECE_Notio Aigaio & 1.10 \\
\hline EL65 & GREECE_Kriti & 5.79 \\
\hline HU11 & HUNGARY_Kozep-Magyarorszag & -15.97 \\
\hline HU21 & HUNGARY_Kozep-Dunantul & -3.01 \\
\hline HU22 & HUNGARY_Nyugat-Dunantul & -2.39 \\
\hline HU23 & HUNGARY_Del-Dunantul & -0.10 \\
\hline HU31 & HUNGARY_eszak-Magyarorszag & -1.00 \\
\hline HU32 & HUNGARY_eszak-Alfold & -1.27 \\
\hline HU33 & HUNGARY_Del-Alfold & 1.95 \\
\hline IE04 & IRELAND_Border Midlands & -10.96 \\
\hline IE05 & IRELAND_Southern and Eastern & -10.50 \\
\hline ITC1 & ITALY_Piemonte & -1.94 \\
\hline ITC2 & ITALY_Valle dAosta Vallee dAoste & 1.33 \\
\hline ITC3 & ITALY_Liguria & 1.48 \\
\hline ITC4 & ITALY_Lombardia & 11.53 \\
\hline ITH1 & ITALY_Bolzano-Bozen & 0.50 \\
\hline ITH2 & ITALY_Provincia Autonoma Trento & -0.35 \\
\hline
\end{tabular}




\begin{tabular}{|c|c|c|}
\hline ITH3 & ITALY_Veneto & 7.70 \\
\hline ITH4 & ITALY_Friuli-Venezia Giulia & 1.19 \\
\hline ITH5 & ITALY_Emilia-Romagna & 7.52 \\
\hline ITI1 & ITALY_Toscana & 2.27 \\
\hline ITI2 & ITALY_Umbria & -0.52 \\
\hline ITI3 & ITALY_Marche & -1.56 \\
\hline ITI4 & ITALY_Lazio & 1.77 \\
\hline ITF1 & ITALY_Abruzzo & -4.06 \\
\hline ITF2 & ITALY_Molise & 0.68 \\
\hline ITF3 & ITALY_Campania & -8.05 \\
\hline ITF4 & ITALY_Puglia & -5.07 \\
\hline ITF5 & ITALY_Basilicata & 0.31 \\
\hline ITF6 & ITALY_Calabria & -3.16 \\
\hline ITG1 & ITALY_Sicilia & -2.70 \\
\hline ITG2 & ITALY_Sardegna & -5.66 \\
\hline LT01 & LITHUANIA_Lietuva & -8.13 \\
\hline LU00 & LUXEMBOURG_Luxembourg (Grand-D) & -1.95 \\
\hline LV00 & LATVIA_Latvija & -0.77 \\
\hline MT00 & MALTA_Malta & -10.49 \\
\hline NL11 & NETHERLANDS_Groningen & -11.40 \\
\hline NL12 & NETHERLANDS_Friesland & -0.61 \\
\hline NL13 & NETHERLANDS_Drenthe & 1.08 \\
\hline NL21 & NETHERLANDS_Overijssel & -2.52 \\
\hline NL22 & NETHERLANDS_Gelderland & 1.27 \\
\hline NL23 & NETHERLANDS_Flevoland & -7.57 \\
\hline NL31 & NETHERLANDS_Utrecht & 3.20 \\
\hline NL32 & NETHERLANDS_Noord-Holland & -0.50 \\
\hline NL33 & NETHERLANDS_Zuid-Holland & -0.04 \\
\hline NL34 & NETHERLANDS_Zeeland & -5.88 \\
\hline NL41 & NETHERLANDS_Noord-Brabant & -0.79 \\
\hline NL42 & NETHERLANDS_Limburg (NL) & 1.75 \\
\hline PL71 & POLAND_Lódzkie & -0.64 \\
\hline PL92 & POLAND_Mazowieckie & -10.95 \\
\hline PL21 & POLAND_Malopolskie & -2.61 \\
\hline PL22 & POLAND_Slaskie & 1.65 \\
\hline PL81 & POLAND_Lubelskie & 3.99 \\
\hline PL82 & POLAND_Podkarpackie & 1.82 \\
\hline PL72 & POLAND_Swietokrzyskie & 2.65 \\
\hline PL84 & POLAND_Podlaskie & 1.56 \\
\hline PL41 & POLAND_Wielkopolskie & -2.32 \\
\hline PL42 & POLAND_Zachodniopomorskie & 3.86 \\
\hline PL43 & POLAND_Lubuskie & 0.82 \\
\hline PL51 & POLAND_Dolnoslaskie & -6.33 \\
\hline PL52 & POLAND_Opolskie & 3.17 \\
\hline PL61 & POLAND_Kujawsko-Pomorskie & 2.42 \\
\hline PL62 & POLAND_Warminsko-Mazurskie & 3.60 \\
\hline PL63 & POLAND_Pomorskie & -1.37 \\
\hline PT11 & PORTUGAL_Norte & 3.49 \\
\hline PT15 & PORTUGAL_Algarve & 1.25 \\
\hline PT16 & PORTUGAL_Centro (PT) & 1.91 \\
\hline
\end{tabular}




\begin{tabular}{|c|c|c|}
\hline PT17 & PORTUGAL_Lisboa & 1.87 \\
\hline PT18 & PORTUGAL_Alentejo & 5.15 \\
\hline SE11 & SWEDEN_Stockholm & -0.76 \\
\hline SE12 & SWEDEN_ostra Mellansverige & 4.06 \\
\hline SE22 & SWEDEN_Sydsverige & 6.86 \\
\hline SE31 & SWEDEN_Norra Mellansverige & 6.83 \\
\hline SE32 & SWEDEN_Mellersta Norrland & 2.66 \\
\hline SE33 & SWEDEN_ovre Norrland & -1.58 \\
\hline SE21 & SWEDEN_Småland med oarna & 8.99 \\
\hline SE23 & SWEDEN_Västsverige & 5.20 \\
\hline SI03 & SLOVENIA_Slovenija & 5.12 \\
\hline SK01 & SLOVAKIA_Bratislavský kraj & -2.83 \\
\hline SK02 & SLOVAKIA_Zapadne Slovensko & 3.57 \\
\hline SK03 & SLOVAKIA_Stredne Slovensko & 3.54 \\
\hline SK04 & SLOVAKIA_Východne Slovensko & 6.37 \\
\hline UKC1 & UK_Tees Valley and Durham & 6.61 \\
\hline UKC2 & UK_Northumberland Tyne and Wear & -0.43 \\
\hline UKD1 & UK_Cumbria & 3.16 \\
\hline UKD3 & UK_Cheshire & -0.64 \\
\hline UKD4 & UK_Greater Manchester & 2.07 \\
\hline UKD6 & UK_Lancashire & 6.66 \\
\hline UKD7 & UK_Merseyside & 1.34 \\
\hline UKE1 & UK_East Riding, North Lincolnshire & 2.50 \\
\hline UKE2 & UK_North Yorkshire & 3.25 \\
\hline UKE3 & UK_South Yorkshire & -0.38 \\
\hline UKE4 & UK_West Yorkshire & 3.41 \\
\hline UKF1 & UK_Derbyshire and Nottinghamshire & 3.88 \\
\hline UKF2 & UK_Leicestershire Rutland & 3.40 \\
\hline UKF3 & UK_Lincolnshire & 0.86 \\
\hline UKG1 & UK_Herefordshire Worcestershire & 8.18 \\
\hline UKG2 & UK_Shropshire and Staffordshire & 4.58 \\
\hline UKG3 & UK_West Midlands & 10.04 \\
\hline UKH1 & UK_East Anglia & 2.80 \\
\hline UKH2 & UK_Bedfordshire Hertfordshire & 11.09 \\
\hline UKH3 & UK_Essex & 4.48 \\
\hline UKI4 & UK_Inner London & -4.75 \\
\hline UKI5 & UK_Outer London & 11.58 \\
\hline UKJ1 & UK_Berkshire Bucks Oxfordshire & 5.56 \\
\hline $\mathrm{UKJ} 2$ & UK_Surrey East and West Sussex & 8.40 \\
\hline UKJ3 & UK_Hampshire and Isle of Wight & 1.03 \\
\hline UKJ4 & UK_Kent & 7.64 \\
\hline UKK1 & UK_Gloucestershire Wiltshire & 1.69 \\
\hline UKK2 & UK_Dorset and Somerset & 3.93 \\
\hline UKK3 & UK_Cornwall and Isles of Scilly & -3.02 \\
\hline UKK4 & UK_Devon & -1.15 \\
\hline UKL1 & UK_West Wales and The Valleys & 8.01 \\
\hline UKL2 & UK_East Wales & 9.32 \\
\hline UKM5 & UK_North Eastern Scotland & -1.49 \\
\hline UKM7 & UK_Eastern Scotland & 5.78 \\
\hline UKM8 & UK_South Western Scotland & 9.46 \\
\hline
\end{tabular}


Table B.5. Positive regional change in value-added shares in the GVCs Europeanisation scenario (Figure 9)

\begin{tabular}{|c|c|c|}
\hline$\overline{\mathrm{CODE}}$ & $\overline{\text { COUNTRY_REGION }}$ & $\begin{array}{r}\text { Output Gains } \\
\text { (percentage) }\end{array}$ \\
\hline$\overline{\mathrm{AT} 11}$ & AUSTRIA_Burgenland & 9.74 \\
\hline AT12 & AUSTRIA_Niederosterreich & 10.56 \\
\hline AT13 & AUSTRIA_Wien & 10.39 \\
\hline AT21 & AUSTRIA_Karnten & 10.64 \\
\hline AT22 & AUSTRIA_Steiermark & 10.53 \\
\hline AT31 & AUSTRIA_Oberosterreich & 10.73 \\
\hline AT32 & AUSTRIA_Salzburg & 10.64 \\
\hline AT33 & AUSTRIA_Tirol & 10.47 \\
\hline AT34 & AUSTRIA_Vorarlberg & 11.85 \\
\hline BE10 & BELGIUM_Region de Bruxelles & 12.51 \\
\hline BE21 & BELGIUM_Prov. Antwerpen & 16.27 \\
\hline BE22 & BELGIUM_Prov. Limburg (B) & 17.11 \\
\hline BE23 & BELGIUM_Prov. Oost-Vlaanderen & 13.71 \\
\hline BE24 & BELGIUM_Prov. Vlaams Brabant & 15.92 \\
\hline BE25 & BELGIUM_Prov. West-Vlaanderen & 16.47 \\
\hline BE31 & BELGIUM_Prov. Brabant Wallon & 17.53 \\
\hline BE32 & BELGIUM_Prov. Hainaut & 13.52 \\
\hline BE33 & BELGIUM_Prov. Liege & 15.66 \\
\hline BE34 & BELGIUM_Prov. Luxembourg (B) & 16.43 \\
\hline BE35 & BELGIUM_Prov. Namur & 14.33 \\
\hline CZ01 & CZECH REPUBLIC_Praha & 14.10 \\
\hline $\mathrm{CZ02}$ & CZECH REPUBLIC_Stredni Cechy & 16.34 \\
\hline CZ03 & CZECH REPUBLIC_Jihozapad & 15.75 \\
\hline CZ04 & CZECH REPUBLIC_Severozapad & 15.32 \\
\hline CZ05 & CZECH REPUBLIC_Severovychod & 16.07 \\
\hline CZ06 & CZECH REPUBLIC_Jihovychod & 15.73 \\
\hline CZ07 & CZECH REPUBLIC_Stredni Morava & 15.71 \\
\hline CZ08 & CZECH REPUBLIC_Moravskoslezko & 16.15 \\
\hline DE11 & GERMANY_Stuttgart & 11.80 \\
\hline DE12 & GERMANY_Karlsruhe & 11.28 \\
\hline DE13 & GERMANY_Freiburg & 10.92 \\
\hline DE14 & GERMANY_Tubingen & 11.36 \\
\hline DE21 & GERMANY_Oberbayern & 11.14 \\
\hline DE22 & GERMANY_Niederbayern & 10.69 \\
\hline DE23 & GERMANY_Oberpfalz & 11.27 \\
\hline DE24 & GERMANY_Oberfranken & 10.72 \\
\hline DE25 & GERMANY_Mittelfranken & 11.03 \\
\hline DE26 & GERMANY_Unterfranken & 10.89 \\
\hline DE27 & GERMANY_Schwaben & 10.91 \\
\hline DE30 & GERMANY_Berlin & 9.64 \\
\hline DE40 & GERMANY_Brandenburg - Nordost & 9.66 \\
\hline DE50 & GERMANY_Bremen & 10.94 \\
\hline DE60 & GERMANY_Hamburg & 9.07 \\
\hline DE71 & GERMANY_Darmstadt & 11.34 \\
\hline
\end{tabular}




\begin{tabular}{|c|c|c|}
\hline DE72 & GERMANY_Giessen & 10.57 \\
\hline DE73 & GERMANY_Kassel & 10.48 \\
\hline DE80 & GERMANY_Mecklenburg-Vorpommern & 8.61 \\
\hline DE91 & GERMANY_Braunschweig & 11.26 \\
\hline DE92 & GERMANY_Hannover & 10.41 \\
\hline DE93 & GERMANY_Luneburg & 8.69 \\
\hline DE94 & GERMANY_Weser-Ems & 10.23 \\
\hline DEA1 & GERMANY_Dusseldorf & 8.63 \\
\hline DEA2 & GERMANY_Koln & 8.76 \\
\hline DEA3 & GERMANY_Munster & 8.59 \\
\hline DEA4 & GERMANY_Detmold & 10.60 \\
\hline DEA5 & GERMANY_Arnsberg & 9.10 \\
\hline DEB1 & GERMANY_Koblenz & 9.85 \\
\hline DEB2 & GERMANY_Trier & 9.14 \\
\hline DEB3 & GERMANY_Rheinhessen-Pfalz & 9.18 \\
\hline DEC0 & GERMANY_Saarland & 10.76 \\
\hline DED2 & GERMANY_Chemnitz & 9.42 \\
\hline DED4 & GERMANY_Dresden & 10.37 \\
\hline DED5 & GERMANY_Leipzig & 9.03 \\
\hline DEE0 & GERMANY_Sachsen-Anhalt & 8.88 \\
\hline DEF0 & GERMANY_Schleswig-Holstein & 8.67 \\
\hline DEG0 & GERMANY_Thüringen & 9.89 \\
\hline DK01 & DENMARK_Hovedstadsreg & 10.83 \\
\hline DK02 & DENMARK_Ost for Storebælt & 10.69 \\
\hline DK03 & DENMARK_West_for_Storebelt & 10.79 \\
\hline EE00 & ESTONIA_Eesti & 8.00 \\
\hline ES11 & SPAIN_Galicia & 3.20 \\
\hline ES12 & SPAIN_Principado de Asturias & 3.90 \\
\hline ES13 & SPAIN_Cantabria & 4.29 \\
\hline ES21 & SPAIN_Pais Vasco & 4.44 \\
\hline ES22 & SPAIN_Foral de Navarra & 4.21 \\
\hline ES23 & SPAIN_La Rioja & 4.42 \\
\hline ES24 & SPAIN_Aragon & 3.90 \\
\hline ES30 & SPAIN_Comunidad de Madrid & 5.12 \\
\hline ES41 & SPAIN_Castilla y Leon & 3.36 \\
\hline ES42 & SPAIN_Castilla-la Mancha & 3.65 \\
\hline ES43 & SPAIN_Extremadura & 3.55 \\
\hline ES51 & SPAIN_Cataluna & 4.97 \\
\hline ES52 & SPAIN_Comunidad Valenciana & 4.37 \\
\hline ES53 & SPAIN_Illes Balears & 3.09 \\
\hline ES61 & SPAIN_Andalucia & 2.60 \\
\hline ES62 & SPAIN_Region de Murcia & 4.21 \\
\hline ES63 & SPAIN_Ceuta (ES) & 3.50 \\
\hline ES64 & SPAIN_Melilla (ES) & 3.70 \\
\hline ES70 & SPAIN_Canarias_ES & 2.90 \\
\hline FI19 & FINALND_Ita-Suomi & 5.98 \\
\hline FI1B & FINALND_Etela-Suomi & 5.33 \\
\hline FI1C & FINALND_Lansi-Suomi & 5.56 \\
\hline FI1D & FINALND_Pohjois-Suomi & 6.90 \\
\hline FI20 & FINALND_Aland & 5.13 \\
\hline
\end{tabular}




\begin{tabular}{|c|c|c|}
\hline FR10 & FRANCE_Ile de France & 4.47 \\
\hline FRF2 & FRANCE_Champagne-Ardenne & 6.89 \\
\hline FRE2 & FRANCE_Picardie & 4.77 \\
\hline FRD2 & FRANCE_Haute-Normandie & 6.95 \\
\hline FRB0 & FRANCE_Centre & 4.69 \\
\hline FRD1 & FRANCE_Basse-Normandie & 6.11 \\
\hline FRC1 & FRANCE_Bourgogne & 4.98 \\
\hline FRE1 & FRANCE_Nord - Pas-de-Calais & 4.71 \\
\hline FRF2 & FRANCE_Lorraine & 4.62 \\
\hline FRF1 & FRANCE_Alsace & 5.31 \\
\hline FRC2 & FRANCE_Franche-Comte & 5.16 \\
\hline FRG0 & FRANCE_Pays de la Loire & 4.93 \\
\hline FRH0 & FRANCE_Bretagne & 3.96 \\
\hline FRI3 & FRANCE_Poitou-Charentes & 4.65 \\
\hline FRI1 & FRANCE_Aquitaine & 4.15 \\
\hline FRJ2 & FRANCE_Midi-Pyrenees & 4.42 \\
\hline FRI2 & FRANCE_Limousin & 5.53 \\
\hline FRK2 & FRANCE_Rhone-Alpes & 5.94 \\
\hline FRK1 & FRANCE_Auvergne & 7.30 \\
\hline FRJ1 & FRANCE_Languedoc-Roussillon & 5.55 \\
\hline FRL0 & FRANCE_Provence-Alpes-Cote d Azur & 6.25 \\
\hline FRM0 & FRANCE_Corse & 6.93 \\
\hline EL30 & GREECE_Anatoliki Makedonia Thraki & 0.61 \\
\hline EL41 & GREECE_Kentriki Makedonia & 0.67 \\
\hline EL42 & GREECE_Dytiki Makedonia & 0.60 \\
\hline EL43 & GREECE_Thessalia & 0.47 \\
\hline EL51 & GREECE_Ipeiros & 0.68 \\
\hline EL52 & GREECE_Ionia Nisia & 0.70 \\
\hline EL53 & GREECE_Dytiki Ellada & 0.46 \\
\hline EL54 & GREECE_Sterea Ellada & 0.56 \\
\hline EL61 & GREECE_Peloponnisos & 0.74 \\
\hline EL62 & GREECE_Attiki & 0.65 \\
\hline EL63 & GREECE_Voreio Aigaio & 0.87 \\
\hline EL64 & GREECE_Notio Aigaio & 0.64 \\
\hline EL65 & GREECE_Kriti & 0.62 \\
\hline HU11 & HUNGARY_Kozep-Magyarorszag & 9.88 \\
\hline HU21 & HUNGARY_Kozep-Dunantul & 10.29 \\
\hline HU22 & HUNGARY_Nyugat-Dunantul & 10.73 \\
\hline HU23 & HUNGARY_Del-Dunantul & 8.68 \\
\hline HU31 & HUNGARY_eszak-Magyarorszag & 9.04 \\
\hline HU32 & HUNGARY_eszak-Alfold & 8.41 \\
\hline HU33 & HUNGARY_Del-Alfold & 8.90 \\
\hline IE04 & IRELAND_Border Midlands & 9.22 \\
\hline IE05 & IRELAND_Southern and Eastern & 10.61 \\
\hline ITC1 & ITALY_Piemonte & 5.10 \\
\hline ITC2 & ITALY_Valle dAosta Vallee dAoste & 3.09 \\
\hline ITC3 & ITALY_Liguria & 3.25 \\
\hline ITC4 & ITALY_Lombardia & 4.78 \\
\hline ITH1 & ITALY_Bolzano-Bozen & 2.74 \\
\hline ITH2 & ITALY_Provincia Autonoma Trento & 3.78 \\
\hline
\end{tabular}




\begin{tabular}{|c|c|c|}
\hline ITH3 & ITALY_Veneto & 4.58 \\
\hline ITH4 & ITALY_Friuli-Venezia Giulia & 4.09 \\
\hline ITH5 & ITALY_Emilia-Romagna & 4.51 \\
\hline ITI1 & ITALY_Toscana & 4.46 \\
\hline ITI2 & ITALY_Umbria & 3.75 \\
\hline ITI3 & ITALY_Marche & 4.33 \\
\hline ITI4 & ITALY_Lazio & 4.40 \\
\hline ITF1 & ITALY_Abruzzo & 3.86 \\
\hline ITF2 & ITALY_Molise & 3.73 \\
\hline ITF3 & ITALY_Campania & 3.92 \\
\hline ITF4 & ITALY_Puglia & 3.88 \\
\hline ITF5 & ITALY_Basilicata & 3.48 \\
\hline ITF6 & ITALY_Calabria & 3.83 \\
\hline ITG1 & ITALY_Sicilia & 3.78 \\
\hline ITG2 & ITALY_Sardegna & 4.18 \\
\hline LT01 & LITHUANIA_Lietuva & 4.45 \\
\hline LU00 & LUXEMBOURG_Luxembourg (Grand-D) & 16.49 \\
\hline LV00 & LATVIA_Latvija & 4.16 \\
\hline MT00 & MALTA_Malta & 6.08 \\
\hline NL11 & NETHERLANDS_Groningen & 17.42 \\
\hline NL12 & NETHERLANDS_Friesland & 12.91 \\
\hline NL13 & NETHERLANDS_Drenthe & 14.96 \\
\hline NL21 & NETHERLANDS_Overijssel & 16.30 \\
\hline NL22 & NETHERLANDS_Gelderland & 11.58 \\
\hline NL23 & NETHERLANDS_Flevoland & 15.93 \\
\hline NL31 & NETHERLANDS_Utrecht & 12.67 \\
\hline NL32 & NETHERLANDS_Noord-Holland & 14.84 \\
\hline NL33 & NETHERLANDS_Zuid-Holland & 17.82 \\
\hline NL34 & NETHERLANDS_Zeeland & 17.47 \\
\hline NL41 & NETHERLANDS_Noord-Brabant & 15.76 \\
\hline NL42 & NETHERLANDS_Limburg (NL) & 13.52 \\
\hline PL71 & POLAND_Lódzkie & 6.75 \\
\hline PL92 & POLAND_Mazowieckie & 7.61 \\
\hline PL21 & POLAND_Malopolskie & 6.73 \\
\hline PL22 & POLAND_Slaskie & 7.15 \\
\hline PL81 & POLAND_Lubelskie & 7.69 \\
\hline PL82 & POLAND_Podkarpackie & 6.62 \\
\hline PL72 & POLAND_Swietokrzyskie & 7.74 \\
\hline PL84 & POLAND_Podlaskie & 7.51 \\
\hline PL41 & POLAND_Wielkopolskie & 8.13 \\
\hline PL42 & POLAND_Zachodniopomorskie & 7.08 \\
\hline PL43 & POLAND_Lubuskie & 7.68 \\
\hline PL51 & POLAND_Dolnoslaskie & 6.85 \\
\hline PL52 & POLAND_Opolskie & 7.94 \\
\hline PL61 & POLAND_Kujawsko-Pomorskie & 6.96 \\
\hline PL62 & POLAND_Warminsko-Mazurskie & 7.94 \\
\hline PL63 & POLAND_Pomorskie & 7.15 \\
\hline PT11 & PORTUGAL_Norte & 3.11 \\
\hline PT15 & PORTUGAL_Algarve & 2.90 \\
\hline PT16 & PORTUGAL_Centro (PT) & 3.11 \\
\hline
\end{tabular}




\begin{tabular}{|c|c|c|}
\hline PT17 & PORTUGAL_Lisboa & 3.28 \\
\hline PT18 & PORTUGAL_Alentejo & 3.18 \\
\hline SE11 & SWEDEN_Stockholm & 8.34 \\
\hline SE12 & SWEDEN_ostra Mellansverige & 9.32 \\
\hline SE22 & SWEDEN_Sydsverige & 9.32 \\
\hline SE31 & SWEDEN_Norra Mellansverige & 6.54 \\
\hline SE32 & SWEDEN_Mellersta Norrland & 5.64 \\
\hline SE33 & SWEDEN_ovre Norrland & 7.26 \\
\hline SE21 & SWEDEN_Småland med oarna & 10.43 \\
\hline SE23 & SWEDEN_Västsverige & 9.86 \\
\hline SI03 & SLOVENIA_Slovenija & 5.31 \\
\hline SK01 & SLOVAKIA_Bratislavský kraj & 11.73 \\
\hline SK02 & SLOVAKIA_Zapadne Slovensko & 11.34 \\
\hline SK03 & SLOVAKIA_Stredne Slovensko & 10.42 \\
\hline SK04 & SLOVAKIA_Východne Slovensko & 10.55 \\
\hline UKC1 & UK_Tees Valley and Durham & 8.63 \\
\hline UKC2 & UK_Northumberland Tyne and Wear & 8.42 \\
\hline UKD1 & UK_Cumbria & 10.49 \\
\hline UKD3 & UK_Cheshire & 10.14 \\
\hline UKD4 & UK_Greater Manchester & 7.15 \\
\hline UKD6 & UK_Lancashire & 10.16 \\
\hline UKD7 & UK_Merseyside & 6.69 \\
\hline UKE1 & UK_East Riding, North Lincolnshire & 10.71 \\
\hline UKE2 & UK_North Yorkshire & 9.01 \\
\hline UKE3 & UK_South Yorkshire & 7.64 \\
\hline UKE4 & UK_West Yorkshire & 8.43 \\
\hline UKF1 & UK_Derbyshire and Nottinghamshire & 7.83 \\
\hline UKF2 & UK_Leicestershire Rutland & 10.53 \\
\hline UKF3 & UK_Lincolnshire & 8.20 \\
\hline UKG1 & UK_Herefordshire Worcestershire & 9.52 \\
\hline UKG2 & UK_Shropshire and Staffordshire & 9.09 \\
\hline UKG3 & UK_West Midlands & 8.68 \\
\hline UKH1 & UK_East Anglia & 8.10 \\
\hline UKH2 & UK_Bedfordshire Hertfordshire & 7.73 \\
\hline UKH3 & UK_Essex & 8.10 \\
\hline UKI4 & UK_Inner London & 8.58 \\
\hline UKI5 & UK_Outer London & 7.85 \\
\hline UKJ1 & UK_Berkshire Bucks Oxfordshire & 8.47 \\
\hline UKJ2 & UK_Surrey East and West Sussex & 8.35 \\
\hline UKJ3 & UK_Hampshire and Isle of Wight & 10.16 \\
\hline UKJ4 & UK_Kent & 9.75 \\
\hline UKK1 & UK_Gloucestershire Wiltshire & 10.73 \\
\hline UKK2 & UK_Dorset and Somerset & 8.67 \\
\hline UKK3 & UK_Cornwall and Isles of Scilly & 8.43 \\
\hline UKK4 & UK_Devon & 8.59 \\
\hline UKL1 & UK_West Wales and The Valleys & 7.99 \\
\hline UKL2 & UK_East Wales & 7.96 \\
\hline UKM5 & UK_North Eastern Scotland & 6.96 \\
\hline UKM7 & UK_Eastern Scotland & 8.02 \\
\hline UKM8 & UK_South Western Scotland & 9.22 \\
\hline
\end{tabular}


